\title{
Geology of the \\ Near Islands, Alaska
}

By OLCOTT GATES, HOWARD A. POWERS, and RAY E. WILCOX

With a section on SURFICIAL GEOLOGY

By JOHN P. SCHAFER

INVESTIGATIONS OF ALASKAN VOLCANOES

GE OL O G I A L S U R VEY B U L L E T I N 1028-U

Prepared in cooperation with the

Departments of the Army, Navy, and Air Force

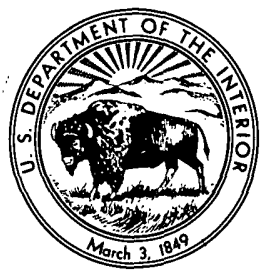


UNITED STATES DEPARTMENT OF THE INTERIOR

GEOLOGIGAL SURVEY

William T. Pecora, Director

Library of Congress catalog-card No. 72-609789

ir 


\section{PREFACE}

In October 1945 the War Department (later, Department of the Army) requested the U.S. Geological Survey to undertake a program of volcano investigations in the Aleutian Islands-Alaska Peninsula area. The first field studies, under the general direction of G. D. Robinson, were made during 1946-48. The results of the first year's field, laboratory, and library work were hastily assembled as two administrative reports, and most of these data have been revised for publication in Geological Survey Bulletin 1028. Part of the early work was published in 1950 in Bulletin 974-B, "Volcanic Activity in the Aleutian Arc," and in 1951 in Bulletin 989-A, "Geology of Buldir Island, Aleutian Islands, Alaska," both by Robert R. Coats. During 1949-54, additional fieldwork was carried out under the direction of H. A. Powers. Unpublished results of the early work and all the later studies are incorporated as parts of Bulletin 1028. The geological investigations covered by this chapter of Bulletin 1028 were reconnaissance, and most of the results were written in the present form by 1956. The factual information presented is believed to be accurate, but many of the tentative interpretations and conclusions will be modified as knowledge grows.

The investigations of 1946 were supported almost entirely by the Military Intelligence Division of the Office, Chief of Engineers, U.S. Army. From 1947 to 1955 the Departments of the Army, Navy, and Air Force joined to furnish financial and logistic assistance. The Geological Survey. is indebted to the Office, Chief of Engineers, for its early recognition of the value of geologic studies in the Aleutian region, and to the several military departments for their support. 



\section{CONTENTS}

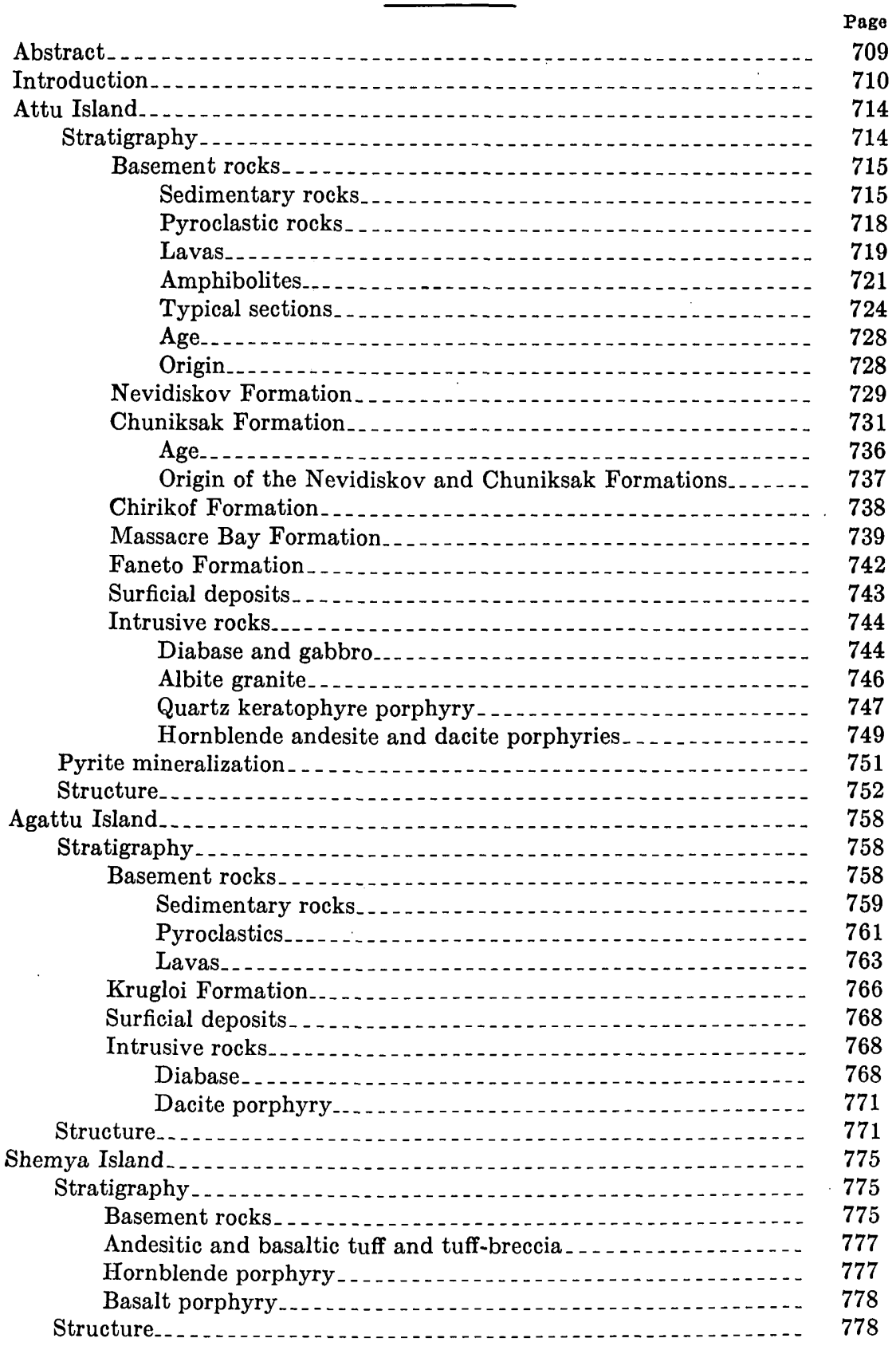


Surficial geology of the Near Islands, by John P. Schafer.

Pre-Wisconsinan marine erosion.

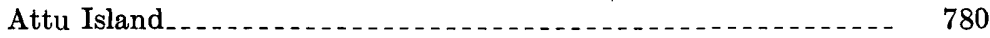

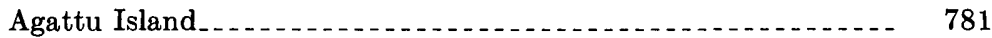

Semichi Islands_...

Terrace correlations...

Glaciation

Glacial erosion .................... 784

Glacial deposition .

Glacial history

Postglacial stream action.

Erosion . .

Deposition

Postglacial marine action. 792

Marine erosion

Sea cliffs.

Shore platforms

Marine shoreline deposition. 797

Changes of altitude. 801

Wind action

Frost action . .

Frost-breaking of rock

Mass movement of frost-broken material _... $\ldots \ldots \ldots 4$

Turf-banked terraces and stone stripes.

Frost-produced ponds and tussocks _........ 809

Early postglacial frost action

Summary of geologic history of the Near Islands .

References cited._.

Index

\section{ILLUSTRATIONS}

Page

Plate 80. Geologic map of Attu, Near Islands, Alaska...... In pocket

81. Geologic map and sections of Agattu, Near Islands,

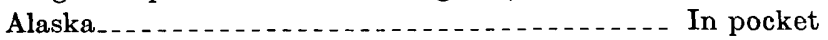

82. Structural trend map of Agattu, Near Islands,

Alaska........ In pocket

Figure 105. Map of Aleutian Islands, Alaska, showing location of Near Islands.

106-110. Photographs:

106. Laminated cherty and argillitic basement rocks, East Arm of Nevidiskov Bay, Attu _-

107. Laminated basement rocks, East Arm of Nevidiskov Bay, Attu.................

108. Limy nodule in Chuniksak Formation, Chuniksak Point, Attu. ..............

109. Quartz keratophyre dike, Steller Cove, Attu - -

110. Andesitic dikes intruding basement conglomerates, Abraham Bay, Attu........ 
Figure 111. Geologic map of basement rocks (Mesozoic or Tertiary)

on east shore of Casco Point, Massacre Bay, Attu--
112. Photograph showing varicolored laminated siltstone,

Page chert, and argillite of the basement rocks on the north

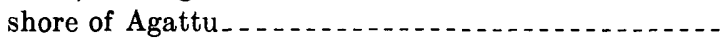

113. Photograph showing thin-bedded siltstone between basaltic tuff-breccia units of the basement rocks on the north shore of Agattu.

114. Rose diagram of fracture trends on Agattu. . . . . .

115. Geologic map of Shemya. . . . . 776 116-121. Photographs:

116. Raised marine terraces transected by sea cliff, Mikhail Point, Attu.........

117. Plateau on Agattu.

118. Raised marine platform, western quarry, Shemya..............................

119. Furrowed trough wall, postglacial gullies, and alluviated valley floor in West Steller Valley, Attu.............................

120. Shore platform, inactive sea cliff, and colluvial bench, Chuniksak Point, Attu .....

121. Shore platform, inactive sea cliff, and colluvial bench, Armeria Bay, Agattu.......

122. Sketch of shore profiles, Auburn Cove, Etienne Bay, and Murder Point Peninsula, Attu........

123. Photograph showing turf-banked terraces, Peak 5, Agattu. . . .

\section{TABLES}

1. Chemical data for rocks of the Near Islands, Aleutian

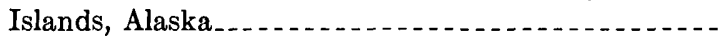

2. Results of insoluble-residue tests on rock specimens from the Chuniksak Formation, Attu........... 


\title{
GEOLOGY OF THE NEAR ISLANDS, ALASKA
}

\author{
By Olcott Gates, Howard A. Powers, and Ray E. Whcox
}

\begin{abstract}
The Near Islands, westernmost group of the Aleutian Islands chain, are composed of volcanic and sedimentary rocks and minor amounts of intrusive rocks ranging from possible Mesozoic age through late Tertiary or early Quaternary age. Six formations are herein named. Unconsolidated surficial deposits of Quaternary age occur on all the islands. In contrast to most of the rest of the Aleutian Islands, the Near Islands do not have any Holocene or historically active volcanoes, and their present morphological character was determined mainly by preglacial marine and subaerial erosion.

The islands rise from a submerged platform, probably planated largely by marine action, and form the crest of the long arc-shaped Aleutian Ridge. The north flank of the ridge is apparently a steep fault scarp descending to the flat Bering Sea floor. The south flank is less steep and is deeply indented by submarine canyons of probable tectonic origin; it is separated from the Pacific Ocean floor by the Aleutian trench.

Most of Attu Island is made up of coarse marine clastic rocks, laminated chert and argillite, and submarine pyroclastics and pillow lavas, many of which are spilitic or keratophyric. Locally the volcanic rocks have been metamorphosed to amphibolite. These basement rocks are late Mesozoic or early Tertiary in age. The younger Nevidiskov Formation is chiefly marine conglomerates, and the overlying Chuniksak Formation is predominantly fine-banded siliceous and limy marine argillites and siltstones. The Chirikof Formation, possibly equivalent to the Nevidiskov or Chuniksak Formations, is chiefly marine conglomerates. The Massacre Bay and Faneto Formations contain mainly subaerial conglomerate and volcanic rocks. Diabase and gabbro form prominent sills and dikes cutting the Chuniksak and older formations, and small albite granite plutons are associated with some of them. Hornblende porphyry intrudes the Massacre Bay and older formations and is distinctly younger than the diabase.

On Agattu Island the basement rocks are fine-banded siliceous marine sediments, pyroclastics, and mafic (in part spilitic) lavas. The slightly younger Krugloi Formation includes only minor amounts of lavas. The basement rocks and the Krugloi Formation are of late Mesozoic or early Tertiary age and possibly are the same age as parts of the basement rocks of Attu. Diabase is the predominant intrusive rock on Agattu, and rhyodacite porphyry is subordinate.
\end{abstract}


On Shemya Island the basement rocks are marine sediments and pyroclastics and lavas, of Tertiary age, which are possibly equivalent to the Massacre Bay Formation of Attu. A younger sequence of bedded tuffs is of Tertiary or Quaternary age. Shallow intrusives include hornblende dacite porphyry and basalt.

The structure of the Near Islands is dominated by faults that appear to be mostly of the normal and strike-slip types. The regional structure on Attu is greatly obscured because of the abundance of faults and the lack of stratigraphic marker beds. On Agattu the regional picture is that of a broad anticline plunging gently southeast, with some minor drag folding. A history of frequent tectonic movements is shown by upraised marine planated platforms of both preglacial and postglacial age; similar platforms below present sea level are inferred from detailed submarine topography. Uneroded low fault scarps across unconsolidated deposits attest to the recency of some tectonic movements along old fault zones intermittently active since late Tertiary.

The effects of only one glaciation, presumably that of late Wisconsinan Age, can be seen, although very probably there were several previous glaciations. The maximum extent of the ice was well beyond the present shorelines. Since the waning of the ice, stream erosion and deposition have been slight. Frost action has been the chief postglacial agent in the breakdown of surface rocks and movement of material down slopes.

Recent marine erosion has cut prominent flat shore platforms in rock at tide level. These platforms are backed by steep cliffs, and some platforms are as much as a quarter of a mile wide. They are possibly the combined result of breakdown of the rock by frost action and removal of disintegration products by storm waves.

The geological history of the Near Islands area may be summarized as follows: In late Mesozoic time and probably continuing into early Tertiary time, deposition of marine fine-grained sediments and conglomerates was accompanied by copious submarine eruptions of mafic lavas and pyroclastics. In early Tertiary time, deposition of more marine banded fine-grained sediments was followed by intrusion of diabase dikes, sills, and minor soda granite and keratophyric bodies. In middle Tertiary time, general uplift brought the deposits up to and above sea level, and then a long period of subaerial and marine erosion ensued. Andesitic lavas and pyroclastics predominate among the upper Tertiary igneous rocks, and these are associated with generally subaerial sedimentary deposits. Pleistocene ice spread from island centers beyond the present shorelines, leaving few deposits on land.

\section{INTRODUCTION}

The Near Islands are the westernmost group in the chain of American Aleutian Islands extending southwest and west from the tip of the Alaskan Peninsula (fig. 105). The group consists of Attu, Agattu, Shemya, Alaid, and Nizki Islands; the last three are known as the Semichi Islands. The Near Islands group forms a triangle, with Attu at the western corner, Agattu at the southern corner, and Shemya at the eastern corner. Agattu is about 25 miles southeast of Attu, and the Semichi Islands are about 20 miles east-southeast of Attu. The group lies between long $172^{\circ} 22^{\prime}$ and $174^{\circ} 12^{\prime} \mathrm{E}$. and between lat $52^{\circ} 21^{\prime}$ and $53^{\circ} 01^{\prime} \mathrm{N}$. Attu has an area of about 300 square miles, and Agattu, about 50 square miles; the three Semichi Islands 


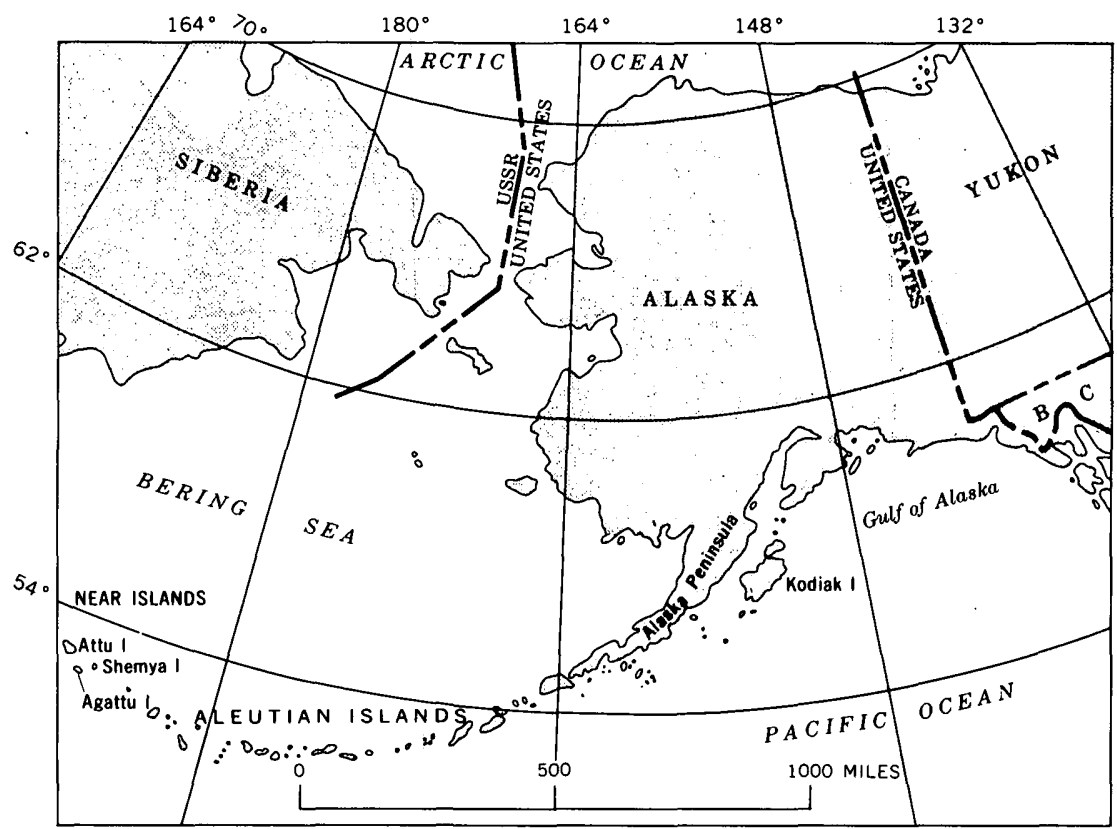

Frgure 105.-Map of Aleutian Islands, Alaska, showing location of Near Islands.

each have an area of less than 5 square miles. Attu, Agattu, and Shemya were mapped by reconnaissance methods during the summers of 1949 and 1950 as part of a mapping program in the Aleutian Islands by the U.S. Geological Survey. Alaid and Nizki Islands were not investigated.

The Near Islands are relatively inaccessible. Shemya in 1949-50 was a refueling stop on military and commercial air routes to and from Japan. A U.S. Coast Guard cutter or U.S. Navy vessel called occasionally at Attu and Shemya but not at Agattu. Transportation for the U.S. Geological Survey parties to and from the Aleutians was provided by the Military Air Transport Service, and transportation from camp to camp was provided by the U.S. Geological Survey vessel Eider, which each summer made the voyage from Seattle.

Weather and logistics restricted the field season to about 2 months each summer. Personnel in the 1949 field season were Howard A. Powers, Ray E. Wilcox, Frank M. Byers, Jr., Olcott Gates, George L. Snyder, Edgar J. Huizer, Harald Drewes, and William J. McMannis. In the 1950 field season, geologists were Powers, Wilcox, Gates, Snyder, Drewes, John P. Schafer, Samuel L. Moore, C. L. Sainsbury, Richard J. Rongey, and C. Dean Rinehart. In addition, during the 1950 season Philip C. Scruton carried out a program of oceanography in the Near Islands area from the U.S. Geological Survey vessel 
Eider through a cooperative agreement with Scripps Institution of Oceanography.

The topographic base maps used for Attu and Shemya were made by the U.S. Army Map Service at a scale of 1:25,000 and had a 50-foot contour interval. Those used for Agattu were unpublished maps made by the U.S. Coast and Geodetic Survey at a scale of 1:20,000 and had a 50-foot contour interval. Locations were made by inspection of topography and by aneroid barometer. Time was not available to map the geology in as much detail as the map scales might allow, and the amount of detail and the accuracy of the mapping, particularly on Attu, depended a great deal on the accessibility of the terrain, the weather, and logistic problems.

In the eastern quarter of Attu a few military roads were still usable at the time of this reconnaissance. The rest of the island was without roads or trails, and transportation was by foot over rugged and mountainous terrain or by ship along the shoreline and small boat to landings in protected coves. Agattu is less mountainous than Attu and was completely without roads. Shemya is flat and has a dense network of roads and airstrips.

The vessel supporting the fieldwork was the Eider, an 80-foot diesel-powered former halibut-fishing schooner carrying a crew of six, including the master. The most common field procedure was to land a party of four at the head of a conveniently located bay or cove and there establish a base camp. From the base camp the men worked in pairs, either on day traverses or to temporary camps. Radio contacts were made periodically with the Eider and with other base camps; and when as much territory as feasible had been covered from the base camp, the Eider returned to move the party to the site of the next camp. In this manner most of the area of the islands could be reached by traverses along beaches, valleys, and ridges. A distinct disadvantage of the procedure was the lack of opportunity to restudy a puzzling area after obtaining stratigraphic or structural keys from other areas examined later, or to visit and compare areas covered by other members of the party.

Logistic and financial support from the United States military forces made the project possible. Complete cooperation was given by Headquarters Alaskan Command, Fort Richardson, Alaska; the Military Air Transport Command; the Commanding Officer, Naval Operating Base, Adak; Commanding Officer, Shemya Air Force Base; and the Officer in Charge, U.S. Naval Weather Station, Attu. The U.S. Geological Survey field parties were very fortunate in having competent help from Master Carl Vevelstad, engineer Charles Best, and crew of the U.S. Geological Survey motorship Eider in the 
many difficult beach landings and in aerial support of the field parties.

The climate of the Near Islands is wet and stormy, and low clouds and fog are common. Summers are cool and winters are moderate. The following data (U.S. Army Air Force, 1945, p. 14, 16) on Attu (Alexai Point) and Shemya cover 22 months in 1943-45.

\begin{tabular}{|c|c|}
\hline Attu & Shemya \\
\hline Mean annual temperature. & $38.9^{\circ} \mathrm{F}$ \\
\hline Lowest monthly mean temperature $\ldots \ldots \ldots 29.4^{\circ}$ (Jan.) & $30.2^{\circ}$ (Jan.) \\
\hline Highest monthly mean temperature $\ldots . . .51 .0^{\circ}$ (Aug.) & $50.6^{\circ}$ (Aug.) \\
\hline Absolute maximum temperature $\ldots \ldots \ldots 63.0^{\circ}$ (Aug.) & $60.0^{\circ}$ (Aug.) \\
\hline Absolute minimum temperature...... & $18.0^{\circ}$ (Jan.-Mar.) \\
\hline Mean annual precipitation & 24.75 in. \\
\hline Mean annual snowfall............ & $67.2 \mathrm{in.}$ \\
\hline
\end{tabular}

During the summer months visibility is less than 2 miles about 40 percent of the time, and over the whole year it is less than 2 miles about 20 percent of the time. Average wind velocity during June, July, and August is about 14 miles per hour, and for the whole year it is about 18 miles per hour. Snowdrifts remain at altitudes as low as 400 feet in mid-June, and snow remains all summer in gullies and on shaded slopes of the mountainous areas at altitudes above 1,500 feet. Cloud ceiling at about 500 to 1,000 feet much of the time during the summer effectively obscures the mountainous areas. Frequent cyclonic storms begin to sweep the Aleutian Islands in September.

The predominant soil type of the Near Islands is tundra (Kellogg and Nygard, 1951), and the land vegetation is limited to low-growing forms, dominantly mosses, lichen, fungi, grasses, low shrubs, and a profusion of wildflowers. A thick blanket of soggy turf grows in areas at low altitudes that have enough soil for a roothold, such as in the alluviated valley bottoms, in areas of ground moraine, or in areas of residual rock mantle. Grasses are plentiful along the beaches at the mouths of the main valleys, especially on Attu, where some of the grasses in the flat valley floors attain a height of at least 6 feet. Areas at altitudes above 2,000 feet, except those that are protected and on dormant talus slopes, are generally free of the soggy turf.

Animal life includes an abundance of sea birds and foxes. Insects are few, and biting insects, such as mosquitoes, are absent. Sea and littoral life consists of sea lions, seals, porpoises, whales, an abundance of sea urchins and gastropods, and a variety of pelecypods. During August many salmon and Dolly Varden trout can be found in the lower parts of the main streams, but strictly fresh-water fish were not observed.

No Aleuts inhabit the Near Islands at this time. The village of Attu at Chicagof Harbor was destroyed during World War II, and 
no natives have returned to the island. Many Aleut middens scattered along the shorelines of the islands indicate a former native population of considerable size. Most of the middens are on the postglacial raised wave-cut benches that girdle the islands about 6-10 feet above present mean tide level and especially on low points having sandy or gravelly beaches.

Very little has been published concerning the geology of the Near Islands. Capps (1934) described the general geomorphology of Attu and some of the rocks in the vicinity of Chicagof Harbor. Coats (1956) gave a few brief notes on Attu, based on reconnaissance; and Sharp (1946) gave a few notes on Agattu, based on a short visit. Kondo $(1931)^{1}$ briefly described an albite granite collected from the north shore of Attu. Gates and Gibson (1956) described and discussed the submarine topography of the Near Islands, and Scruton (1953) discussed the bottom deposits of the Near Islands shelf.

\section{ATTU ISLAND}

\section{STRATIGRAPHY}

The basement rocks (pl. 80) are submarine pyroclastic rocks, columnar and pillow lava flows, and marine argillites, sandstones, graywackes, and conglomerates. In some areas the volcanic rocks are spilitic or keratophyric; in other areas they have been converted to amphibolites. The total thickness of the basement rocks is more than 7,000 feet, and their age is presumed to be late Mesozoic or early Tertiary.

The Nevidiskov Formation of middle Tertiary age, which lies unconformably on the basement rocks, consists of about 1,000 feet of conglomerate. Overlying it in gradational contact is the Chuniksak Formation, of possible Miocene age, which consists of several thousand feet of fine-grained laminated siliceous, argillitic, and limy sedimentary rocks.

The Chirikof Formation, near the eastern end of the island, consists of conglomerate, sandstone, a few carbonaceous shale layers, and possibly one lava flow. The Chirikof is nowhere seen in contact with the other formations, but it probably rests unconformably on the basement rocks and may be equivalent in age to the Nevidiskov or Chuniksak Formations.

The Massacre Bay Formation consists of subaerial lava flows, pyroclastics, and coarse clastics, 500 feet or more thick, resting unconformably on the basement rocks. Its age is late Tertiary or early Pleistocene.

\footnotetext{
I We are Indebted to Prof. H. Kuno of the Geological Institute, Tokyo University, for calling this paper to our attention and for furnishing an English translation.
} 
The Faneto Formation consists of about 1,500 feet of coarse red subaerial clastics that lie unconformably on the Chuniksak Formation and the basement rocks. Its age is late Tertiary or early Pleistocene.

The oldest intrusive rocks of the region are represented by isolated occurrences of blocks of albite granite in tuffs and lavas of the basement rocks. Sills, dikes, and irregular small bodies of gabbro and diabase, as well as several small bodies of albite granite, are probably of middle Tertiary (perhaps Miocene) age. Possibly some that cut only the basement rocks, for example, may be correspondingly older. The scattered small dikes and stocks of hornblende andesite and dacite that cut the basement rocks and the Nevidiskov and Chuniksak Formations may be equivalent in age to the Massacre Bay Formation (late Tertiary or early Pleistocene). Quartz keratophyre dikes range in age from early Tertiary to early Pleistocene. Veins of pyritic mineralization cut rocks of all ages up to the Pleistocene gravels.

\section{BASEMENT ROCKS}

The oldest, thickest, and most widespread rocks on Attu are siliceous and argillaceous marine sedimentary rocks, conglomerates, and submarine lava flows and pyroclastics. The mapping was not sufficiently detailed to untangle the complicated system of faults nor the rapid facies changes. The 7,000 feet of scattered and uncorrelated measured sections include but a fraction of the total thickness of the rocks exposed. Probably a thickness of 10,000 to 15,000 feet is not too high an estimate.

\section{SEDIMENTARY ROGKS}

Detritus in the basement rocks is at least as great in volume as the pyroclastics and lavas. For purposes of description the sedimentary rocks are here divided into two types: fine sediments (medium-sand particle size or smaller) and coarse sediments (coarse sand up to cobble conglomerate). These two types are shown separately on the geologic map, plate 80 , where known.

The fine-grained sedimentary rocks-chert, siliceous siltstone, argillite, limestone, and fine tuffaceous graywacke-occur in thin varicolored black, green, red, yellow, and gray beds. Some beds are several inches to several feet thick with graded textures; others are thin laminae as sharp and fine as a pencil line (figs. 106 and 107). Many chert, argillite, silty, and tuffaceous beds, some only 1 inch or so thick, can be traced for hundreds of feet along the strike. Others, however, form short lenses in coarser sedimentary rocks. Convolute or intricately folded bedding is common; in many places the 


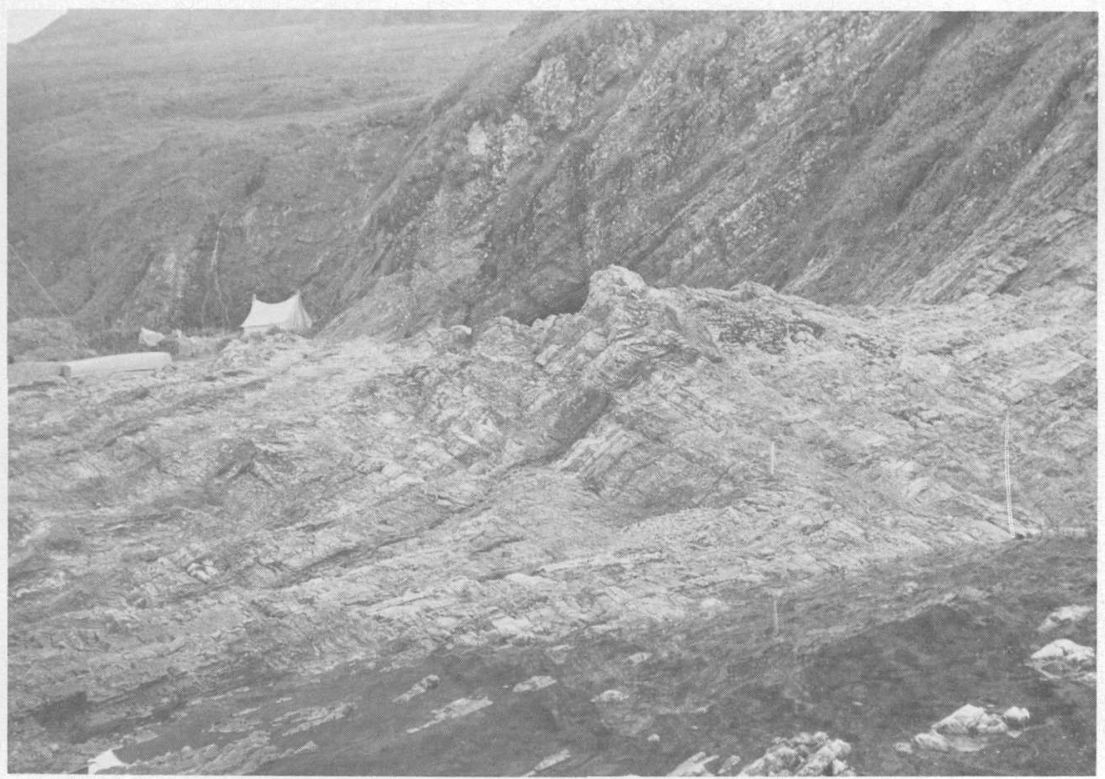

Figure 106.-Lamfnated cherty and argillitic basement rocks, dipping westward, East Arm of Nevidiskov Bay, Attu.

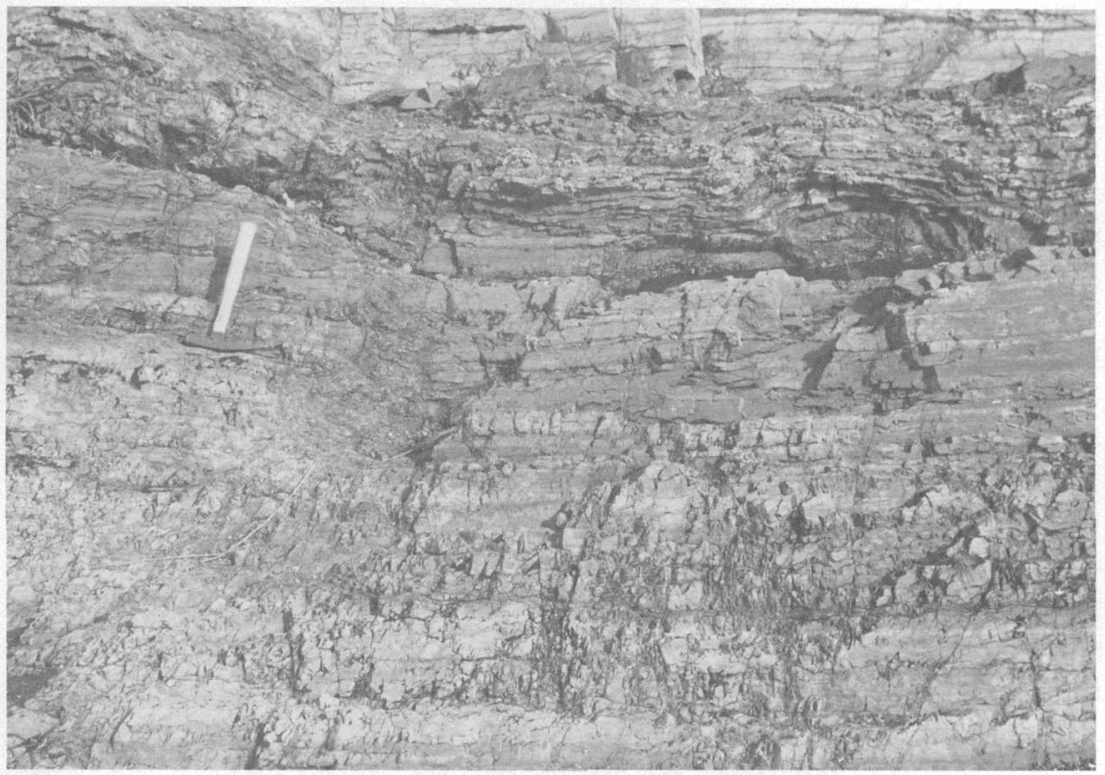

Figure 107.--Laminated basement rocks. Closeup of area shown left of hammer in figure 106, East Arm of Nevidiskov Bay, Attu. 
folds are confined to several beds between undeformed beds. Some of the siltstone and fine-grained graywacke beds show small-scale crossbedding, slight erosional unconformities between beds, and mud chips or mud balls along their bases. Similar structures have been cited by Kuenen (1953) as typical of sediments deposited by turbidity currents.

These fine-grained sedimentary rocks occur as thin laminae in coarse tuff beds, as contorted lenses in pillow lavas, and as groups of beds a few feet to several tens of feet thick intercalated with pillow lavas, coarse graywacke, and conglomerate. They also form continuous well-bedded sequences several hundreds of feet thick that are overlain and underlain by volcanic rocks and coarse clastics.

Under the microscope, these fine-grained siliceous sedimentary rocks are seen to be made up of minute fragments, usually angular to subround, of quartz, feldspar, chlorite, pyroxene, and opaque materials in a matrix of isotropic material (silica?) and scattered lenses of green chloritic material. Many have irregular blotches of epidote and calcite that are apparently secondary. The limestones contain widely scattered fragments of the same materials. Calcareous Foraminifera, diatoms, and siliceous radiolaria are seen in many of the slides, but their state of preservation is too poor to permit specific identification.

Though many of the fragments seem to be products of weathering of lava, some angular fragments of fresh feldspar and pyroxene may be broken crystals from unweathered fine pyroclastic material and may be either primary or reworked. However, there is a general absence of glassy shards, and the amount of quartz exceeds pyroxene, in contrast to the relative preponderance of pyroxene over quartz in most identifiable associated tuffs.

Coarse graywacke and conglomerate, interbedded with pillow lavas, pyroclastics, and fine siliceous sedimentary rocks, are especially common in the basement rocks in the triangular area between Kresta Point, Mikhail Point, and Austin Cove. In contrast to the varicolored siliceous sedimentary rocks, the graywacke and conglomerate outcrops are generally a drab dark gray, grayish purple, or grayish green. The graywackes form thin beds, with good sorting, some crossbedding, and slight scouring and erosional irregularities between beds. In many places they are interlayered with siltstone, argillite, and small-pebble conglomerate. The pebble-and-cobble conglomerates generally have thick crude irregular bedding, poor sorting, and many lenses of coarse graywacke or small-pebble conglomerate. Many conglomerate beds are massive, a jumble of all grain sizes, without definite sedimentary structure. 
Rock fragments, primarily of basaltic and keratophyric lava, range from very round (suggesting beach material) to subangular. Other rock types represented are tuff, tuff-breccia, laminated siliceous rock, argillite, limestone, graywacke, and pebble conglomerate. All are rock types within the basement rocks; no fragments of potash feldspar, mica granite, gneiss, or schist were found. Many of the conglomerate beds have a green tuffaceous and chloritic matrix suggesting intermixing of pyroclastic material with other detrital rock fragments. Other conglomerates have a sandy or mixed sand and clay matrix that is apparently mostly detrital. The matrix of conglomerate adjacent to albite granite or gabbro intrusive rocks is locally so recrystallized, feldspathized, and silicified that the original composition and details of texture are obscure.

\section{PYROGLASTIC ROCKS}

Beds of basaltic, spilitic, and keratophyric tuff and lapilli tuff are numerous, and in some areas of the basement rocks, as at Casco Point, they equal the pillow lavas in aggregate thickness. Tuffs in the basement rocks are found in all parts of the island but are most. abundant on Chirikof Point, in the area between Massacre Bay and Temnac Bay south of Peaceful Valley to Temnac Point, along the west shore of Temnac Bay, and in the area between Holtz Bay and Austin Cove on the north shore.

The interbedding of pyroclastics with pillow flows and fine marine sedimentary rocks shows that the environment of deposition was marine. Bed thicknesses range from a few feet to as much as 100 feet. Some beds are massive and show no indication of sorting. Others have bedding that grades from coarse bomb-filled lapilli tuff at the base to a fine silt-size tuff at the top. In still others, bedding is distinct and there is a marked difference in grain size between adjacent beds. Some contacts between beds are irregular and apparently indicate scouring by slight erosion; other contacts are sharp and straight. Lenses and streaks of pyroclastic material, of different grain size than the enclosing material, wander through some of the tuffs irregularly but generally as crudely developed crossbedding. Some tuffs are finely laminated with individual laminae only two or three grains thick. A conspicuous feature in several fine-grained tuffs is the contorted and intricately folded bedding, indicating deformation prior to consolidation.

Submarine volcanic agglomerates and breccias are associated with the basaltic and keratophyric tuffs of the basement rocks. On the south shore of Murder Point a volcanic breccia is well exposed on a wave-cut bench. Angular to subround blocks, as much as 1 foot in 
diameter, of basalt, keratophyre lavas, and rarely albite granite are imbedded in a mottled pale-green and white tuff matrix. The crude bedding is much contorted, folded, and minutely faulted. Volcanic breccias extend along the north shore of Attu west of Austin Cove to Kresta Point. These are associated with pillow flows, graywackes, and coarse conglomerates. Large rock fragments consist of several varieties of porphyritic lavas. Matrices are less tuffaceous than the breccias associated with primarily tuffaceous material.

The basaltic tuffs associated with the basement lavas and sedimentary rocks, especially in the vicinity of Theodore Point and Chirikof Point, offer an interesting variation of mild alteration effects. In hand specimens and outcrops they have an oily dark-green color. Under the microscope it is seen that augite has remained unaffected but the plagioclase has been converted to analcite, and analcite fills interstices. The original basaltic glass in the pyroclastic material has been converted to a green to green-brown birefringent substance which resembles the nontronitic alteration of basaltic glass described by Allen and Scheid (1946). These basaltic tuffs are similar to those of Agattu Island, of which representative specimens have been chemically analyzed, and are described in the section on the basement rocks of Agattu.

LAVAS

Pillow lava flows are conspicuous in the basement rocks and are excellently exposed on Murder Point and Sanders Cape. The flows range in thickness from 1 foot to several tens of feet, and they are generally black, dark purple, or purplish green. Individual pillows range in longest horizontal dimension from 2 to 20 feet; 3 to 6 feet is the predominant size range. Shape of pillows ranges from almost round in cross section to flat ellipsoidal, like a partly inflated balloon with a flat bottom and a curving top. Each pillow has an outside glassy-appearing selvage a fraction of an inch thick in small pillows and 3 to 4 inches thick in large pillows. This selvage is commonly well jointed perpendicular to the surface of the pillow. Inside the pillow, jointing may or may not be conspicuous; but if present, the joints have a roughly radial pattern. In addition to the radial jointing, amygdaloidal or porphyritic pillows have a concentric layering of amygdules parallel to the pillow surface and consisting of variations either in size or in concentration of amygdules.

In some pillow flows, the individual pillows fit tightly together. In most, however, there are crudely tetrahedral spaces between pillows, and these spaces are filled with varicolored chert, chalcedony, red jasper, or calcareous mud. This mud is also found in cracks and 
vugs within pillows. In a few flows, notably those on Murder Point, red limestone fills spaces between pillows and may almost surround an individual pillow. Highly colored and banded siliceous argillitic sedimentary rocks underlying some pillow lava flows are contorted and have irregular offshoots squeezed upward into the spaces between the overlying pillows. At the base of one pillow flow, individual pillows were found buried in siliceous mudstone and isolated from the parent flow above. Many flows have contorted laminar siliceous sedimentary rocks between pillows, which suggests that soft muds had been trapped and carried along by the flow. One or two flows, which apparently were injected into muds, contain contorted and irregular finely banded sediments both above and below. Several of the pillow flows observed have rubbly tops; others have smooth knobby tops, preserving the upper contours of the top pillows, and are overlain by parallel-bedded fine sediments which extend down into openings between pillows.

A few lava flows have excellent polygonal columnar jointing perpendicular to the surfaces of the flow. One flow on Murder Point has columnar jointing units within exceptionally large pillows. In a flow at Casco Point, the basal half has columnar jointing and the upper half has pillow structure.

The pillow lavas are mostly basaltic and have a variety of textures, including porphyritic, subophitic, and ophitic. Many are of spilitic character, in that their calcic plagioclase is wholly or partly albite and their soda content is somewhat higher than that of ordinary basalt. Many of the plagioclase crystals have rims of clear albite around cores of cloudy albite flecked with epidote, prehnite, sericite, and carbonate. In some rocks, islands of clear labradorite remain in crystals otherwise made up of the dusty albite. The pyroxene is augitic, and most of it is clear and unaltered. It includes crystals of black opaque oxide. Some rocks contain bowlingite pseudomorphs after olivine. Varying amounts of fine-grained green and brown materials are present in the groundmass along with the plagioclase, pyroxene, and opaque oxide. Zeolites are abundant in the basalts at some localities, as at Theodore Point. A variety of textures are exhibited, including porphyritic, subophitic, and diabasic.

Specimen 50P86 (table 1) is from the base of a pillow flow at Casco Point, Massacre Bay, and is but slightly altered, in contrast to the albite-bearing parts of this same pillow flow. (See 50P85, described below.) This basal material has subophitic texture and contains about 65 percent plagioclase, 20 percent pyroxene, 10 percent olive-brown altered glass mesostasis, and 5 percent opaque oxide and accessories. The plagioclase crystals show normal progressive zoning from $\mathrm{An}_{\ominus \vartheta}$ near the centers down to $\mathrm{An}_{16}$ at the rims of some crystals, as indicated by extinction angles. The pyroxene has faint green pleochroism, (+) $2 \mathrm{~V}=51^{\circ}$, 
and $n \mathrm{Y}=1.692$. According to Hess (1949), these values imply an augite whose composition is about $\mathrm{Ca}_{43} \mathrm{Mg}_{40} \mathrm{Fe}_{17}$.

Specimen 50P85 (table 1) is a spilitic basalt from 40 feet above the base of the pillow flow at Casco Point from which the nonspilitic basaltic specimen 50P86 was taken. The ophitic texture is somewhat less well developed than in $50 \mathrm{P} 86$, and the rock contains about 70 percent albitic plagioclase, 15 percent clear augite, 10 percent chloritic material (mostly altered basaltic glass and vesicle fillings), and 3 percent opaque oxide crystals, sphene, and apatite.

Specimen 50P293 (table 1) from the north shore of Casco Point, Maccacre Bay, is a basaltic lava from a flow, part of which has pillows and part is columnar. It has a subophitic texture with more than the usual amount of microlitebearing altered basaltic glass. By point-counter method it was found to contain 37 percent plagioclase (albite-oligoclase after labradorite), 22 percent fresh augite, 7 percent opaque oxides, and 34 percent altered glass and microlites. The plagioclase is less thoroughly albitized than that of many of the pillow lavas, as many islands of labradorite occur within the dusty albite-oligoclase. The mesostasis is brown nontronitic material containing many skeletal crystals of plagioclase.

Many of the siliceous lavas and tuffs of Attu and the other Near Islands are keratophyres and quartz keratophyres. In their high content of albite and somewhat altered appearance, they are analogous to the spilites; indeed, representative specimens apparently forming a gradational series from spilitic basalts through keratophyres and quartz keratophyres can be assembled, based on the proportions of dark to light minerals. The keratophyric lavas may show columnar structure, and some show well-developed pillow structures. In hand specimen most of the rocks are purplish brown to gray and contain distinct amygdules and prominent phenocrysts of albite, and some also contain quartz.

Specimen 50P280 (table 1) is a quartz keratophyre from a pillow lava at Murder Point. It is the most siliceous (79.56 percent silica) of the analyzed rocks from the Near Islands. In hand specimen it is light gray with a slight purplish cast and is aphanitic except for scattered phenocrysts of white albite. In thin section the albite phenocrysts are subhedral to euhedral, and quartz, although in grains and clumps of phenocryst size, is anhedral. The groundmass consists of a fine felt of albite and quartz with only very minor amounts of opaque oxide as microlite-size rods and chains. Sphene is a sparse but persistent constituent.

\section{AMPHIBOLITES}

Specimen 49G6 (table 1), from the headwaters of Kaufman Creek, is an example of the amphibolites and plagioclase-amphibole rocks in the area between Kaufman Creek and Temnac River. In hand specimen the rock is seen to contain small scattered masses of white feldspar and black hornblende in a very dark groundmass. In thin section the texture is intergranular and in part cataclastic. and the grains range in diameter from 0.1 to $1 \mathrm{~mm}$, but most are less than 0.6 $\mathrm{mm}$. The rock is composed of about 60 percent amphibole, 36 percent plagioclase, 2 percent epidote and zoisite, 1 percent opaque oxide, and 1 percent sphene as crystals, veinlets, and rims about the opaque oxide. Pyrite and hematite occur 
TABLE 1.-Chemical data for rocks of the

\begin{tabular}{|c|c|c|c|c|c|c|c|c|c|c|}
\hline \multirow{2}{*}{$\frac{\text { Location..... }}{\text { Rock type... }}$} & \multicolumn{10}{|c|}{ Attu Island } \\
\hline & \multicolumn{2}{|c|}{ Diabase } & \multicolumn{2}{|c|}{ Pillow lava } & \multirow{2}{*}{$\begin{array}{l}\text { Quartz } \\
\text { diabase }\end{array}$} & \multirow{2}{*}{$\begin{array}{c}\begin{array}{c}\text { Amphi- } \\
\text { bolite }\end{array} \\
\text { Gates }\end{array}$} & \multirow{2}{*}{$\begin{array}{l}\text { Quartz } \\
\text { diabase }\end{array}$} & \multirow{2}{*}{$\begin{array}{c}\begin{array}{c}\text { Pillow } \\
\text { lava }\end{array} \\
\text { Powers }\end{array}$} & \multirow{2}{*}{$\begin{array}{c}\begin{array}{c}\text { Ande- } \\
\text { site }\end{array} \\
\text { Powers }\end{array}$} & \multirow{2}{*}{$\begin{array}{c}\begin{array}{c}\text { Horn- } \\
\text { blende } \\
\text { dacite } \\
\text { porphyry }\end{array} \\
\text { Wilcox }\end{array}$} \\
\hline Collector..... & Wilcox & Wilcox & Powers & Powers & & & & & & \\
\hline Sample No.. & 1 & 2 & 3 & 4 & 5 & 6 & 7 & 8 & 9 & 10 \\
\hline Field No....- & $49 W 26$ & $49 W 21 a$ & $50 \mathrm{P} 86$ & $50 \mathrm{P} 293$ & $50 \mathrm{P} 295$ & $49 \mathrm{G} 6$ & $49 \mathrm{P} 53$ & $50 \mathrm{P} 85$ & $50 \mathrm{P} 286$ & 49W36 \\
\hline $\begin{array}{l}\text { Laboratory } \\
\text { No. } 52-. . .\end{array}$ & 627 & 626 & 628 & 637 & 635 & 644 & 634 & 629 & 636 & 638 \\
\hline
\end{tabular}

Bulk chemical

[Analysts: S. M. Berthold and H. F. Phillips, 1, 2, 3, 8, 14, 17, 18; E. E. Engleman, 4, 5, 7, 9, 10, 16; R. H. Brannock

\begin{tabular}{|c|c|c|c|c|c|c|c|c|c|c|}
\hline $\begin{array}{l}\mathrm{S}_{1} \mathrm{O}_{2} \\
\mathrm{Al}_{2} \mathrm{O}_{3} \\
\mathrm{Fe}_{2} \mathrm{O}_{3} \\
\mathrm{FeO} \\
\mathrm{MgO} \\
\mathrm{CaO} \\
\mathrm{Na}_{2} \mathrm{O} \\
\mathrm{K}_{2} \mathrm{O} \\
\mathrm{H}_{2} \mathrm{O}- \\
\mathrm{H}_{2} \mathrm{O}+ \\
\mathrm{T}\end{array}$ & $\begin{array}{r}47.0 \\
17.2 \\
2.9 \\
6.8 \\
6.6 \\
9.5 \\
3.6 \\
.48\end{array}$ & $\begin{array}{r}48.1 \\
15.3 \\
3.9 \\
6.6 \\
6.2 \\
10.1 \\
3.6 \\
.64\end{array}$ & $\begin{array}{c}\mathbf{4 8 . 4} \\
16.6 \\
7.4 \\
5.2 \\
5.0 \\
9.7 \\
\mathbf{3 . 6} \\
.71\end{array}$ & $\begin{array}{r}49.90 \\
14.97 \\
6.53 \\
5.49 \\
5.95 \\
8.10 \\
4.36 \\
.50 \\
1.73 \\
1.29\end{array}$ & $\begin{array}{r}50.83 \\
13.41 \\
4.65 \\
10.45 \\
4.27 \\
7.82 \\
3.63 \\
.62 \\
.12 \\
2.35\end{array}$ & $\begin{array}{r}51.02 \\
16.30 \\
1.94 \\
7.90 \\
6.27 \\
11.09 \\
2.82 \\
.44 \\
.06 \\
1.24\end{array}$ & $\begin{array}{r}51.40 \\
17.23 \\
2.65 \\
7.70 \\
4.68 \\
10.42 \\
2.49 \\
.32 \\
.38 \\
1.78\end{array}$ & $\begin{array}{c}52.0 \\
16.6 \\
4.0 \\
5.8 \\
4.0 \\
8.8 \\
5.4 \\
.13 \\
\\
\end{array}$ & $\begin{array}{r}55.82 \\
18.63 \\
3.80 \\
1.85 \\
4.34 \\
7.69 \\
3.32 \\
.63 \\
1.77 \\
1.32\end{array}$ & $\begin{array}{r}60.81 \\
17.32 \\
1.70 \\
3.29 \\
2.94 \\
5.77 \\
4.14 \\
1.33 \\
.16 \\
1.48\end{array}$ \\
\hline Ignition loss ${ }^{1}$ - & 3.4 & 2.6 & 2.7 & & & & & 2.6 & & \\
\hline $\mathrm{CO}_{2 \ldots}$ & 1.8 & 2.0 & .99 & $\begin{array}{l}.87 \\
.12\end{array}$ & $\begin{array}{r}1.52 \\
.03\end{array}$ & $\begin{array}{l}.80 \\
.02\end{array}$ & .75 & .86 & $\begin{array}{l}.58 \\
.06\end{array}$ & $\begin{array}{l}.48 \\
.44\end{array}$ \\
\hline $\begin{array}{l}\mathrm{P}_{2} \mathrm{O}_{5} \\
\mathrm{MnO}\end{array}$ & .24 & .17 & .14 & $\begin{array}{r}.14 \\
23\end{array}$ & .18 & .08 & .14 & .12 & .16 & $\begin{array}{l}.15 \\
.10\end{array}$ \\
\hline Total $1 \ldots$ & 99.7 & 99.4 & 100.7 & 100.18 & 100.13 & 100.17 & 100.04 & 100.5 & 100.08 & 100.11 \\
\hline
\end{tabular}

Spectrographic

[Analyst: A. A. Chodos. Looked for but not found: Ag, Au, Pt, W, Ge, Sn, As, Sb, Bi, Cd,

\begin{tabular}{llllllll}
\hline & & & & & \\
\end{tabular}

See footnote at end of table. 
Near Islands, Aleutian Islands, Alaska

\begin{tabular}{|c|c|c|c|c|c|c|c|c|c|c|}
\hline \multicolumn{3}{|c|}{ Attu Island-Continued } & \multicolumn{7}{|c|}{ Agattu Island } & \multirow{3}{*}{$\begin{array}{c}\begin{array}{c}\text { Shemya } \\
\text { Island }\end{array} \\
\begin{array}{l}\text { Horn- } \\
\text { blende } \\
\text { dacite } \\
\text { porphyry }\end{array} \\
\text { Byers }\end{array}$} \\
\hline $\begin{array}{l}\text { Albite } \\
\text { granite }\end{array}$ & $\begin{array}{r}\text { Qus } \\
\text { kerato }\end{array}$ & $\begin{array}{l}\text { rtz } \\
\text { phyre }\end{array}$ & \multicolumn{2}{|c|}{ Basaltic tuff } & $\begin{array}{l}\text { Quartz } \\
\text { diabase }\end{array}$ & Diabase & $\begin{array}{c}\text { Basaltic } \\
\text { tuff }\end{array}$ & $\begin{array}{c}\text { Dacite } \\
\text { por- } \\
\text { phyry }\end{array}$ & $\begin{array}{c}\text { Kera- } \\
\text { tophyre }\end{array}$ & \\
\hline Powers & Powers & Powers & Powers & Wilcox & Powers & Powers & Powers & Drewes & Wilcox & \\
\hline 11 & 12 & 13 & 14 & 15 & 16 & 17 & 18 & 19 & 20 & 21 \\
\hline $50 \mathrm{P} 302$ & 50P312 & $50 \mathrm{P} 280$ & $50 \mathrm{P} 245$ & $50 W 13$ & 50Р269 & 50P244 & 50P250 & $50 \mathrm{D} 4$ & $50 \mathrm{~W} 2$ & 49Bу50 \\
\hline 642 & 641 & 640 & 632 & 643 & 633 & 630 & 631 & 646 & 645 & 639 \\
\hline
\end{tabular}

\section{analysis}

Stokes, $6,11,12,13,15,19,20$. Analyses of samples $1,2,3,8,14,17,18$ made by rapid method (Shapiro and 1952)]

\begin{tabular}{|c|c|c|c|c|c|c|c|c|c|c|}
\hline $\begin{array}{r}71.23 \\
15.22 \\
1.40 \\
.84 \\
.46 \\
.59 \\
7.32 \\
2.08 \\
.05 \\
.19\end{array}$ & $\begin{array}{r}74.59 \\
13.23 \\
.87 \\
.75 \\
.31 \\
1.14 \\
4.58 \\
2.88 \\
.03 \\
.56\end{array}$ & $\begin{array}{r}79.56 \\
11.38 \\
1.19 \\
.28 \\
.14 \\
.41 \\
6.42 \\
.03 \\
.03 \\
.21\end{array}$ & $\begin{array}{r}48.0 \\
15.0 \\
7.5 \\
4.3 \\
5.1 \\
4.7 \\
5.4 \\
1.1 \\
\hdashline . . .\end{array}$ & $\begin{array}{r}48.14 \\
14.54 \\
7.38 \\
5.02 \\
4.78 \\
3.50 \\
6.58 \\
.54 \\
2.47 \\
5.55\end{array}$ & $\begin{array}{r}52.50 \\
15.81 \\
3.02 \\
8.51 \\
4.22 \\
7.06 \\
3.59 \\
.77 \\
.22 \\
2.38\end{array}$ & $\begin{array}{r}53.0 \\
15.2 \\
3.9 \\
9.1 \\
3.7 \\
6.6 \\
3.9 \\
1.2 \\
-. . .\end{array}$ & $\begin{array}{r}54.8 \\
14.8 \\
5.7 \\
5.3 \\
5.4 \\
4.5 \\
6.8 \\
.14 \\
\end{array}$ & $\begin{array}{r}65.54 \\
16.01 \\
1.15 \\
1.62 \\
2.42 \\
3.78 \\
4.97 \\
2.58 \\
.10 \\
.83\end{array}$ & $\begin{array}{r}68.54 \\
13.42 \\
4.83 \\
.86 \\
.95 \\
.90 \\
4.69 \\
3.17 \\
.42 \\
1.27\end{array}$ & $\begin{array}{r}64.06 \\
16.76 \\
2.28 \\
1.44 \\
2.60 \\
6.32 \\
4.02 \\
1.35 \\
.20 \\
.40\end{array}$ \\
\hline $\begin{array}{l}.44 \\
.02 \\
.10 \\
.17\end{array}$ & $\begin{array}{l}.26 \\
.70 \\
.06 \\
.07\end{array}$ & $\begin{array}{l}.33 \\
.02 \\
.06 \\
.03\end{array}$ & $\begin{array}{l}1.2 \\
.15 \\
.26\end{array}$ & $\begin{array}{r}1.22 \\
.01 \\
.18 \\
.23\end{array}$ & $\begin{array}{l}.93 \\
.87 \\
.12 \\
.19\end{array}$ & $\begin{array}{l}1.3 \\
.18 \\
.28\end{array}$ & $\begin{array}{l}1.0 \\
.13 \\
.26\end{array}$ & $\begin{array}{l}.62 \\
.13 \\
.37 \\
.05\end{array}$ & $\begin{array}{l}.79 \\
.01 \\
.20 \\
.11\end{array}$ & $\begin{array}{l}.49 \\
.00 \\
.18 \\
.06\end{array}$ \\
\hline 100.11 & 100.03 & 100.09 & 100.3 & 100.14 & 100.19 & 100.0 & 100.7 & 100.17 & 100.16 & 100.06 \\
\hline
\end{tabular}

analyses

Tl, In, La, Ta, Th, U. Samples 1, 2, 3, 8, 14, 17, and 18 were not analyzed spectrographically]

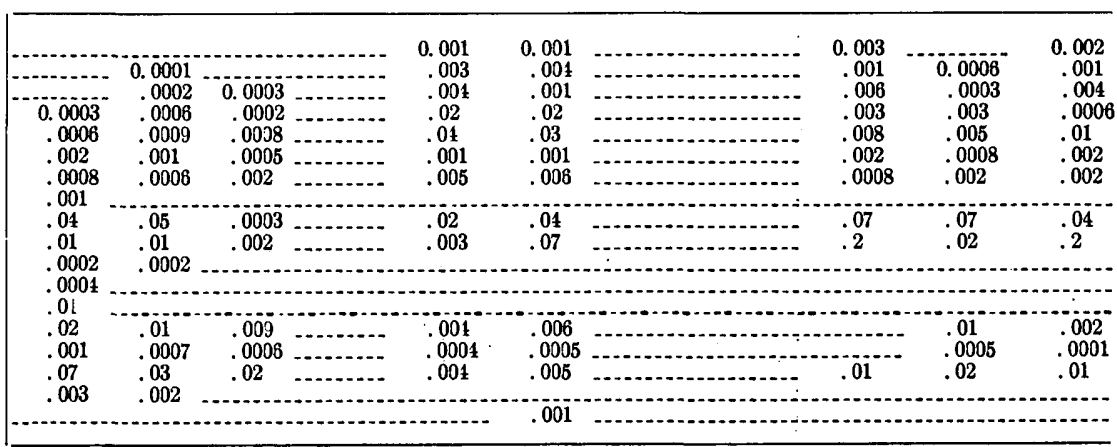


TABLE 1.-Chemical data for rocks of the

\begin{tabular}{|c|c|c|c|c|c|c|c|c|c|c|}
\hline \multirow{2}{*}{ Rocation } & \multicolumn{10}{|c|}{ Attu Island } \\
\hline & \multicolumn{2}{|c|}{ Diabase } & \multicolumn{2}{|c|}{ Pillow lava } & \multirow{2}{*}{$\begin{array}{l}\begin{array}{l}\text { Quartz } \\
\text { diabase }\end{array} \\
\text { Powers }\end{array}$} & \multirow{2}{*}{$\frac{\begin{array}{c}\text { Amphi- } \\
\text { bolite }\end{array}}{\text { Gates }}$} & \multirow{2}{*}{$\begin{array}{l}\begin{array}{r}\text { Quartz } \\
\text { diabase }\end{array} \\
\text { Powers }\end{array}$} & \multirow{2}{*}{$\begin{array}{c}\begin{array}{c}\text { Pillow } \\
\text { lava }\end{array} \\
\text { Powers }\end{array}$} & \multirow{2}{*}{$\begin{array}{c}\begin{array}{c}\text { Ande- } \\
\text { site }\end{array} \\
\text { Powers }\end{array}$} & \multirow{2}{*}{$\frac{\begin{array}{c}\text { Horn- } \\
\text { blende } \\
\text { dacite } \\
\text { porphyry }\end{array}}{\text { Wilcox }}$} \\
\hline Collector & Wilcox & Wilcox & Powers & Powers & & & & & & \\
\hline Sample No_.. & 1 & 2 & 3 & 4 & 5 & 6 & 7 & 8 & 9 & 10 \\
\hline Field No...... & $49 W 26$ & $49 \mathrm{~W} 21 \mathrm{a}$ & $50 \mathrm{P} 86$ & $50 \mathrm{P} 293$ & $50 \mathrm{P} 295$ & $49 \mathrm{G} 6$ & $49 \mathrm{P} 53$ & $50 \mathrm{P} 85$ & $50 \mathrm{P} 286$ & $49 W 36$ \\
\hline $\begin{array}{l}\text { Laboratory } \\
\text { No. 52- }\end{array}$ & 627 & 626 & 628 & 637 & 635 & 644 & 634 & 629 & 636 & 638 \\
\hline
\end{tabular}

CIPW normative

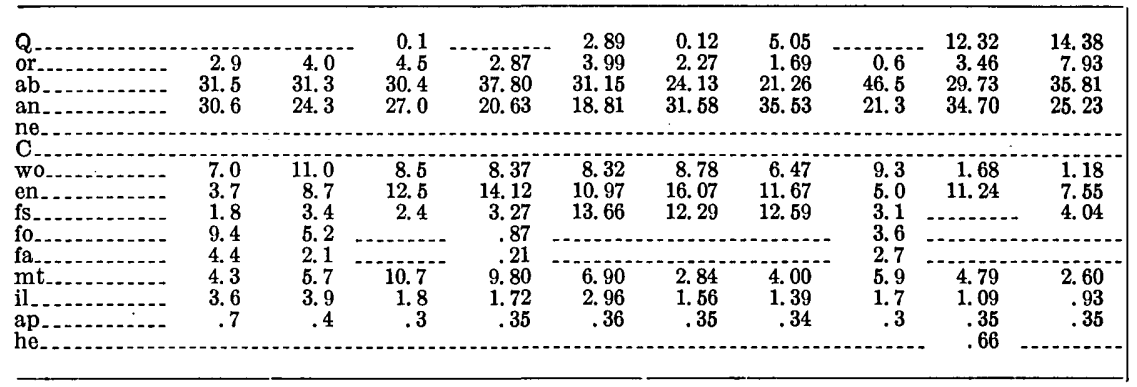

\begin{tabular}{|c|c|c|c|c|c|c|c|c|c|c|}
\hline & & & & & & & & & & Niggli \\
\hline $\begin{array}{l}\text { al } \\
\text { fm } \\
\text { c alk } \\
\text { al } \\
\text { si } \\
\mathrm{qz} \\
\mathrm{k} \\
\mathrm{mg}\end{array}$ & $\begin{array}{r}24.1 \\
42.6 \\
24.3 \\
9.0 \\
112 \\
-24 \\
\quad .08 \\
.55\end{array}$ & $\begin{array}{r}21.6 \\
43.0 \\
26.0 \\
9.4 \\
117 \\
-21 \\
.11 \\
.52\end{array}$ & $\begin{array}{r}23.4 \\
42.2 \\
24.9 \\
9.5 \\
116 \\
-22 \\
.12 \\
.43\end{array}$ & $\begin{array}{r}21.74 \\
45.70 \\
21.45 \\
11.09 \\
123.1 \\
-21.3 \\
.067 \\
.482\end{array}$ & $\begin{array}{c}20.17 \\
48.36 \\
21.41 \\
10.01 \\
130.4 \\
-9.6 \\
.108 \\
.341\end{array}$ & $\begin{array}{c}22.82 \\
41.92 \\
28.23 \\
6.99 \\
121.2 \\
-6.8 \\
.082 \\
.534\end{array}$ & $\begin{array}{c}25.72 \\
39.42 \\
28.31 \\
6.54 \\
130.4 \\
4.2 \\
.070 \\
.444\end{array}$ & $\begin{array}{r}25.4 \\
36.5 \\
24.4 \\
13.7 \\
135 \\
-20 \\
.01 \\
.43\end{array}$ & $\begin{array}{c}32.20 \\
32.55 \\
24.41 \\
10.79 \\
164.5 \\
21.3 \\
.098 \\
.592\end{array}$ & $\begin{array}{c}34.20 \\
28.77 \\
20.72 \\
16.30 \\
204.0 \\
38.8 \\
.173 \\
.517\end{array}$ \\
\hline
\end{tabular}

1 Includes gain due to oxidation of $\mathrm{FeO}$.

sporadically. The amphibole shows bluish-green to pale-yellow-green pleochroism, and the deepest blue-green colors are in the rims. Extinction angle $\mathrm{Z}: c$ ranges from $13^{\circ}$ to $15^{\circ}$, optic angle is large, and $n \mathrm{Y}$ ranges from 1.557 to 1.662 . A patchy clinopyroxene, $\mathrm{Z}: c$ about $38^{\circ}$, composed the core of one large amphibole crystal. The plagioclase crystals show normal progressive zoning from as much as $\mathbf{A n}_{70}$ in the central parts to as low as $\mathrm{An}_{20}$ at the rims. Twin lamellae of some crystals are slightly curved, and the calcic central parts of others are shattered and cemented by sodic plagioclase that is in crystallographic continuity with the generally sodic plagioclase of the rim.

\section{TYPIGAL SECTIONS}

The following columnar sections of the basement rocks in widely separated parts of Attu illustrate the various combinations of the many rock types described in the preceding paragraphs. They cannot be correlated in detail because of abrupt facies changes and the lack of fossils and traceable lithologic horizons. Most of the sections 
Near Islands, Aleutian Islands, Alaska-Continued

\begin{tabular}{|c|c|c|c|c|c|c|c|c|c|c|}
\hline \multicolumn{3}{|c|}{ Attu Island-Continued } & \multicolumn{7}{|c|}{ Agattu Island } & \multirow{2}{*}{$\begin{array}{c}\text { Shemya } \\
\text { Island } \\
\text { Horn- } \\
\text { blende } \\
\text { dacite } \\
\text { porphyry }\end{array}$} \\
\hline $\begin{array}{l}\text { Albite } \\
\text { granite }\end{array}$ & $\underset{\text { keratc }}{\mathrm{Qu}}$ & $\begin{array}{l}\text { artz } \\
\text { phyre }\end{array}$ & Basal & ic tuff & $\begin{array}{r}\text { Quartz } \\
\text { diabase }\end{array}$ & Diabase & $\underset{\text { tuff }}{\text { Basaltic }}$ & $\begin{array}{c}\text { Dacite } \\
\text { por- } \\
\text { phyry }\end{array}$ & $\underset{\text { tophyre }}{\text { Kera- }}$ & \\
\hline Powers & Powers & Powers & Powers & Wilcox & Powers & Powers & Powers & Drewes & $\overline{\text { Wilcox }}$ & Byers \\
\hline 11 & 12 & 13 & 14 & 15 & 16 & 17 & 18 & 19 & 20 & 21 \\
\hline $50 \mathrm{P} 302$ & $50 \mathrm{P} 312$ & $50 \mathrm{P} 280$ & $50 \mathrm{P} 245$ & $50 W 13$ & $50 \mathrm{P} 269$ & $50 \mathrm{P} 244$ & $50 \mathrm{P} 250$ & $50 \mathrm{D} 4$ & $50 \mathrm{~W} 2$ & $49 \mathrm{By} 50$ \\
\hline 642 & 641 & 640 & 632 & 643 & 633 & 630 & 631 & 646 & 645 & 639 \\
\hline
\end{tabular}

minerals

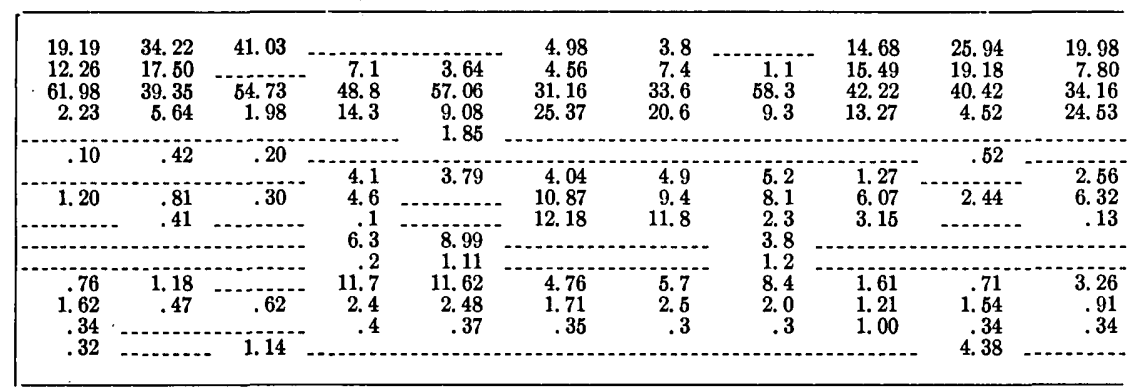

values

\begin{tabular}{|cccccccccccc|}
\hline 43.55 & $\mathbf{4 5 . 5 8}$ & 46.09 & 23.9 & 23.71 & 25.25 & 24.4 & 23.3 & 36.25 & 36.99 & 35.18 \\
12.28 & 10.25 & $\mathbf{8 . 6 4}$ & 46.4 & 47.08 & 43.49 & 43.9 & 45.8 & 22.86 & 27.39 & 23.88 \\
3.22 & 7.07 & 2.88 & 13.6 & 10.51 & 20.52 & 19.3 & 12.9 & 15.70 & 4.52 & 24.09 \\
40.92 & 37.10 & 42.38 & 16.1 & 18.70 & 10.75 & 12.4 & 18.0 & 25.17 & 31.06 & 16.84 \\
370.0 & 439.2 & 545.6 & 130 & 133.9 & 142.5 & 145 & 147 & 252.1 & 322.5 & 227.7 \\
83.3 & 190.8 & 276.1 & -34 & -40.9 & -.5 & -5 & -25 & 51.4 & 98.3 & 60.3 \\
.157 & .295 & .003 & .12 & .054 & .121 & .17 & .02 & .257 & .309 & .177 \\
.286 & .276 & .143 &. .45 & .422 & .397 & .34 & .47 & .616 & .247 & .563 \\
\hline
\end{tabular}

are based on traverses and the distribution of rocks as mapped, and they do not represent detailed or precise measurements. Faults are indicated where they were obvious in the field mapping, but undoubtedly many less obvious faults are present.

\section{Basement rocks west of Holtz Bay}

Approximate thickness (feet)

Top of section is in fault contact with conglomerate of Faneto Formation. Lava, red to black, amygdaloidal ; in flows 1-6 ft thick interbedded with gray tuff and brown argillite

Massive basaltic pillow flows, with thin argillite streaks and jasper interpillow fillings.

Argillite, interbedded cherty siliceous siltstone, fine- to coarse-grained tuffaceous graywacke, lenses of pebble conglomerate, a few thin amygdaloidal lava beds. The entire section very well bedded in beds from 2 in to $6 \mathrm{ft}$ thick

Pillow lava, basaltic, silicified, and altered. 


\section{Basement rocks west of Holtz Bay-Continued}

Hornblende andesite porphyry, intrusive, sill-like; slightly discordant with enclosing beds_

Argillite, green, cherty, finely laminated, very siliceous_-_-_-_-_-_-_--

Argillite, tuff, and thin lava beds, brown to green, interbedded.---.------

Graywacke with scattered lava pebbles, dark-gray, massive, mediumgrained, tuffaceous

Argillite, bluish-gray, with interbedded finely layered cherty brown and yellow tuff and brown and black amygdular lava flows. Section well layered in beds 6 in to $2 \mathrm{ft}$ thick

Finely crystalline bed, gray ; recrystallized tuff, graywacke, or lava

Lava, recrystallized, clusters of feldspars and sheafs and rosettes of hornblende, much jointed and sheared; many white siliceous veinlets

Bottom of section rests on complex of argillite, graywacke, lava, diabasic intrusive rocks much faulted and sheared. Contact obscured by float.

\section{Basement rocks west of Steller Cove}

Top of section is obscured by turf.

Approximate thickness

Pebble conglomerate, gray-green, coarsely bedded; rounded pebbles of argillite, siliceous siltstone, keratophyre, and basalt in matrix of chlorite and carbonate and round to angular grains of feldspar and quartz

Lava, bluish-gray, dense, crystalline

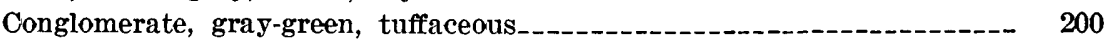

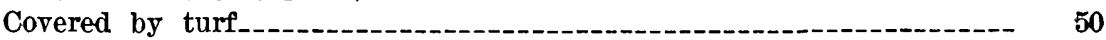

Lava, bluish-gray, fine-grained, massive

Gabbro, intrusive

Lava, dark-gray to black-_._-_-_- 50

Lava, olive-green to gray, amygdaloidal__-_-_-_-_-_-_-_-_-_-_---- 100

Gabbro, intrusive

Pebble conglomerate

Lava flow, dark-green, massive._-_-_-_-_-_-_-_-_-_-_-_-_-_-_-_--- 30

Pebble conglomerate, gray-green tuffaceous; lenses of fine-grained brown sandstone

Lava, dark-purplish-brown; calcite and chlorite amygdules---_-_-_-_--- 20

Fault.

Pebble conglomerate, gray-green; round pebbles of lava, argillite, siltstone in green matrix of chlorite, carbonate, feldspar, quartz, and argillite grains; crude bedding.

Pebble conglomerate, brown tuffaceous sandstone, dark-brown shale

Sandstone, olive-green to brown, well-bedded, coarse, tuffaceous_.___._. $\quad 400$

Pebble conglomerate with interbedded olive-green siltstone

Lava, dark-gray feldspar porphyry

Siltstone, olive-gray, with conglomerate lenses._-_-_._-_._- 150

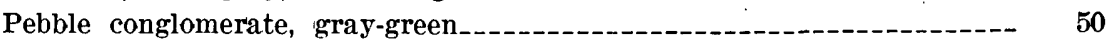

Argillite, brown, splintery

Siltstone, buff, limy, with ironstone layers and warped irregular bedding-- 200

Lava, brown to black, r rse-grained; gray to buff fine-bedded siltstone, pebble conglomerate, black cherty argillite, gray feldspar porphyry lava

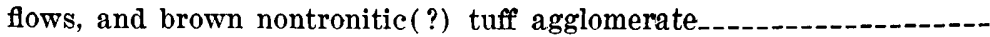
Fault. 


\section{Basement rocks west of Steller Cove-Continued}

Approximate thickness (feet)

Lava flow, light-gray feldspar porphyry

Siltstone, brown, well-bedded; contains a few black cherty argillite beds and two small gabbro dikes; intermittent turf cover.

Pebble conglomerate; round to angular pebbles all of bluish-purple amygdaloidal lava; green tuffaceous matrix

Siltstone, brown, thinly bedded

Lava flow, dark-brown feldspar porphyry

Pebble conglomerate containing clay pebbles and green jasper pebbles.---

Conglomerate, brown, tuffaceous; cherty siltstone, black cherty argillite, gray to brown siltstone

Fault. Bottom of section.

\section{Basement rocks on west shore of Massacre Bay}

[This section, $326 \mathrm{ft}$ thick stratigraphically, lies along the wave-eroded shore platform about 800 yd north of Barabara Point and consists of bed striking N. $80^{\circ} \mathrm{E}$. and dipping $38^{\circ}$ N.]

Top of section covered by present beach gravels.

Approximate thickness

Pebble conglomerate, massive; no bedding; round to angular pebbles of basalt, siltstone, argillite, red mudstone, graywacke; dark-green matrix of chlorite with a few broken feldspar and augite crystals.

Slightly scoured and eroded contact.

Tuff, dull-olive-green, basaltic; fragments of plagioclase, augite, and basalt in dark-green nontronitic matrix.

Gradational contact.

Tuff, dull-olive-green, interbedded with blue siltstone and mudstone layers 2 in. thick containing mud chips

Sandstone, interbedded and interlensing, fine-grained, tuffaceous; coarse tuffaceous sandstone and pebble conglomerate

Slightly scoured and irregular contact.

Tuff, bluish-gray, massive; angular fragments and euhedral crystals of plagioclase and augite in green chloritic matrix; a 1-in.-thick band of blue-gray siltstone

Contact covered.

Sandstone, fine-grained, tuffaceous; bluish-gray siltstone and mudstone in interbedded bands 1-12 in. thick; mud chips and sand pockets common throughout; much wavy streaked bedding suggesting contemporaneous deformation

Sharp straight contiact.

Tuff, dark-blue to purplish-gray. medium- to coarse-grained; angular fragments of plagioclase and partly chloritized ferromagnesian minerals ; generally massive but faint bedding discernible in places; bottom

1 in. is round-pebble conglomerate

Sandstone, fine-grained, tuffaceous ; interbedded with siltstone and mudstone in bands 1-12 in. thick; mud chips and sand pockets_

Sandstone, dark-blue, tuffaceous, fine-grained ; very faint bedding -.-------

Sandstone interbedded with siltstone and mudstone in thin layers, finegrained, tuffaceous

Tuff, dark-purplish-blue; faint bedding; plagioclase and ferromagnesian mineral fragments in dense matrix 


\section{Approximate \\ Basement rocks on west shore of Massacre Bay-Continued thickness}

Limestone, blue and maroon in wavy streaks, silty; layered with interlensing and interbedded slightly sandy layers; contains widely scattered round pebbles of lava or argillite(?) --_-_-

Gradational contact.

Limestone, silty and more sandy thlan one above; numerous rock fragments; no bedding; increasingly sandy toward base

Gradational contact.

Limestone, blue with a few maroon streaks ; layered with irregular sandy streaks

Covered

Limestone, bluish-gray, a few red streaks; layered with irregular sandy lenses

Covered

Limestone, bluish-gray, dense, silty and sandy ; no bedding or layering----

Covered

Tuff, grayish-green; scattered angular fragments of plagioclase and ferromagnesian minerals in dense chloritic matrix; thin wavy layering in a few places

Tuffaceous agglomerate or coarse tuff; angular fragments of plagioclase and ferromagnesian minerals in chloritic matrix

Graywacke, tuffaceous, interbedded and interlensing with blue siltstone; contains a few limy layers

Bottom of section covered by beach gravels. The section continues along beach for several hundred feet, but has more covered areas thlan outcrop. Outcrops are of same general type as in section.

AGE

The basement rocks yielded no fossils and their age is uncertain. They must be older than middle Tertiary because they underlie the Nevidiskov and Chuniksak Formations unconformably, but how much older is unknown. An age assignment of late Mesozoic or early Tertiary is thus speculative.

\section{ORIGIN}

The outstanding characteristic of the basement rocks is their heterogeneity. Pillow lavas, agglomerates, breccias, tuffs, coarse conglomerates, graywackes, argillites, cherts, and limestones are interbedded with one another and grade laterally into one another. A bed only a few millimeters thick may be overlain by coarse unbedded breccia or conglomerate. Contemporary slumping, turbidity flows, crossbedding, and scour-and-fill are found throughout the section. Round pebbles and cobbles derived from subaerial erosion occur in sequences of beds which contain coarse breccias and pyroclastics.

This heterogeneity of rock type reflects heterogeneity in the environment of deposition, in the source area, and in the processes of deposition. Rounded pebbles imply subaerial sources; the characters 
of the volcanic rocks clearly indicate widespread submarine volcanism; and the slumping, chaotic bedding, and structures formed by turbidity currents imply steep gradients which in turn suggest tectonic movements and perhaps also volcanic islands or submarine peaks. However, the finely laminated, primarily siliceous sedimentary rocks suggest quiet deposition at some depth in basins free from currents, wave action, and the dumping of detrital sediments.

\section{NEVIDISKOV FORMATION}

Approximately 1,000 feet of graywacke and conglomerate overlies the basement rocks unconformably and underlies the Chuniksak Formation in the Nevidiskov Bay area. This conglomerate is here named the Nevidiskov Formation for the excellent exposures on the west side of Nevidiskov Creek valley, the type locality. The conglomerate is also exposed on the south end of the ridge between the Nevidiskov Creek and Nevidiskov River valleys and under the Chuniksak argillite in the vicinity of Peak 7B. A small area of conglomerate on the tip of Theodore Point may also belong to the Nevidiskov Formation.

The contact of the Nevidiskov rocks with the overlying Chuniksak Formation is conformable and in part gradational. The upper beds of the Nevidiskov are finer grained than the lower, and lenses of argillite become more and more numerous until finally the typical argillite of the Chuniksak Formation is predominant.

Observations on the relation between the Nevidiskov Formation and the basement rocks are somewhat conflicting. The only exposure of the basal contact is near the type locality of the Nevidiskov Formation; there, on the crest of the ridge north of Kaufman Pass, Nevidiskov conglomerate overlies a sequence of typical interbedded lava flows, argillite, and conglomerate of the basement complex without sharp angular discordance but with possible erosional unconformity. However, it is clear from the mapped relations that the rocks of the Nevidiskov and Chuniksak Formations are much less complexly deformed than most of the basement rocks. Furthermore, the Nevidiskov conglomerates are made up entirely of fragments of rock types present in the basement rocks. Thus it seems probable that the conglomerates of the Nevidiskov Formation were derived from extensive erosion of the basement rocks following both uplift and deformation.

The following sections were measured by aneroid barometer on the west side of Nevidiskov Creek valley. Thicknesses are approximate, and undiscovered faults are undoubtedly present. The sections are presented as a general description of the Nevidiskov Formation and are to be regarded here as reference sections. 
REFERENCE SECTTON A.-Nevidiskov Formation, west side of Nevidiskov Creek valley, about $21 / 2$ miles north of creek mouth

Top of section. Conformable contact with Chuniksak Formation. (See Approximate thickness section p. 735.)

Graywacke, light-brown, massive, fine- to medium-grained

Fine pebble conglomerate alternating with coarse graywacke; beds $2-4$ in. thick; pebbles are subangular to round and composed of lava, argillite, chert, and graywacke

Conglomerate, dark-gray to black, coarse; subangular to round pebbles and cobbles of lava

Feldspar porphyry intrusive, probably a sill

Pebble conglomerate, dark-green, coarse, interbedded with graywacke; pebbles of porphyritic and amygdaloidal lava and argillite; several 1-ftthick lenses of siliceous siltstone and argillite

Argillite, dark-green, and siliceous siltstone

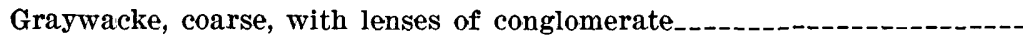

Covered

Graywacke, coarse, with irregular lenses of conglomerate containing pebbles and cobbles of graywacke

Base of section covered by talus. Intermittent outcrops indicate that the section continues downward for at least $200 \mathrm{ft}$.

REFERENCE SECTION B.-Nevidiskov Formation, west side of Nevidiskov Creek valley, about 1 mile south of locality of references section $A$-about 11/2 miles north of creek mouth

Approximate thickness $($ feet $)$

Top of section. Conformable contact with banded limy argillite of the Chunkisak Formation. (See section p. 735.)

Graywacke conglomerate; large angular to subangular boulders of dark feldspar porphyry in green matrix of graywiacke and of conglomerate of argillite and lava pebbles_._._._._.

Graywacke, coarse-grained.-...-...-...--

Graywacke conglomerate; pebbles and cobbles in green matrix

Covered by talus

Graywacke conglomerate, green; contains rounded pebbles and cobbles as much as $2 \mathrm{ft}$ in diameter of dark porphyritic lava, graywacke, and cherty argillite

Covered

Graywacke conglomerate, green; subangular to round pebbles and cobbles as much as 6 in. in diameter mostly of dark porphyritic lava but also of graywacks and cherty argillite

Covered

Graywacke conglomerate with green sandy matrix; round to subround pebbles as much as $1 \mathrm{in}$. in diameter of cherty argillite and black aphianitic porphyritic lava; several thin lenses of cherty argillite

Remainder of section covered. 
Age.-The Nevidiskov Formation is clearly younger than the basement rocks and is conformable below the Chuniksak Formation of probable Miocene age. It is thus considered to be middle Tertiary, perhaps early Miocene or late Oligocene.

A single pecten found in the conglomerate near the base of reference section $B$ proved of no value for establishing the age.

\section{CHUNIKSAK FORMATION}

The Chuniksak Formation, composed of siliceous fine-grained marine sedimentary rocks, is here named for its excellent exposures on Chuniksak Point in the type locality, the area between Nevidiskov Creek and Abraham Bay. It is also exposed in the vicinity of Peak 7B, offset from the Chuniksak Point exposures by one of the major faults on Attu. Highly faulted and deformed rocks of the Chuniksak Formation occur also on the north side of the island along the shoreline northwest of Holtz Bay. In the Chuniksak Point and Peak 7B areas the Chuniksak Formation conformably overlies the Nevidiskov Formation. In the area northwest of Holtz Bay, the base of the Chuniksak Formation is not exposed. There it is unconformably overlain by red conglomerate of the Faneto Formation. The unconformity is a marked erosional and structural contact. A thickness of at least 2,000 feet of the Chuniksak Formation is present in the Chuniksak Point and Peak 7B areas, and the total thickness prior to erosion is unknown.

The fine-grained well-bedded rocks of the Chuniksak Formation tend to weather rapidly to scree of reddish angular chips and small blocks. The hills and mountains underlain by these rocks have smooth rounded contours and are distinctly red, in marked contrast to the typical rugged irregular contours and dark gray of mountains underlain by the basement rocks. Faults show clearly as marked depressions, whereas most intrusives stand out sharply.

The Chuniksak Formation consists of marine sedimentary rocks, principally siliceous shale, argillite, limy argillite, chert, siliceous siltstone, sandstone, sandy shale, graywacke, and a little pebble conglomerate. Limy and siliceous nodules are abundant at a few horizons. In outcrop, the fine-grained siliceous sediments are colorful, being various shades of dark gray, yellow, brown, green, purple, and red. Beds are conspicuous and sharply defined; they range in thickness from less than 1 inch to about 1 foot and are marked at the top and bottom by a distinct, sharp break. The break is commonly straight and without evidence of scour, and acts as a parting plane 
when the rock weathers. Within the beds are many laminations from 1 to several millimeters thick. Some of these are deformed and intricately folded and faulted, whereas in adjacent beds they are consistently parallel to the bedding planes. Repetitions of laminae from bed to bed, but no definite rhythmic banding, are discernible. In general, the lamination is most evident in the argillite and siliceous siltstone and less evident in the siliceous shale, in which it is obscured by splintery or shaly parting. Some beds have thin lenses of sandstone, limy shale, or limestone. Many of these features are strikingly similar to those described by Bramlette (1946) in the Miocene Monterey Formation of California.

Microscopic examination shows that these fine siliceous sedimentary rocks consist of angular to subround fragments of quartz, albite; and labradorite, flakes of biotite and chlorite, masses of calcite and chert, and scattered calcareous Foraminifera and siliceous diatoms. In general, the fragments are not closely packed but are scattered throughout a cryptocrystalline matrix. Grain size ranges from submicroscopic to about $0.2 \mathrm{~mm}$; most grains are between $0.05 \mathrm{~mm}$ and $0.1 \mathrm{~mm}$. The angularity of many feldspar and quartz fragments and the relatively fresh, unweathered appearance of the feldspars, albite and labradorite, suggest derivation from volcanic ash. Numerous irregular blotches, stringers, and wisps of brown to black opaque material are generally parallel to the bedding, but they are irregularly wavy and undulatory and bend under, around, or over the clastic fragments. In a few slides thin films of this material cut across the bedding like a jagged pencil line and show a marked tendency to go around clastic grains. The amount and concentration of this material and the relative density of distribution and size of the clastic fragments appear to be factors determining the prominence of layering. In some of the fine-grained siliceous rocks, cubes of authigenic pyrite have grown across the bedding planes, the opaque stringers, and the clastic grain boundaries. The matrix is a brown to yellow or colorless material, and much of it is cryptocrystalline and contains minute pinpoints and flecks of carbonate and opaque material. This cryptocrystalline material is presumed to be clay minerals, opaline silica, and perhaps analcite.

Some beds are limy, but pure limestone without abundant admixed clastic fragments was found in only a very few beds. The limy beds more commonly alternate with sandy and shaly beds than with argillitic beds. Several specimens of the Chuniksak Formation were tested for their solubility in dilute hydrochloric acid, and their contents of ferric oxide and carbonate inferred from the results are 
given in table 2. The carbonate content ranges widely from bed to bed: in the argillite, from 0.7 percent in sample 8 to 57.0 percent in sample 1 ; in the nodules, from 48.4 percent in sample 14 to 75.4 percent in sample 2.

In thin section, the carbonate appears as an irregularly intergrown mosaic of grains with different orientations and fuzzy boundaries. Scattered through the limestone are fragments of quartz and feldspar like those found in the siliceous rocks, and few of these fragments appear to have been partly replaced by calcite. Euhedral cubic crystals of pyrite are present in some of the limy rocks and are visible in hand specimen as well as under the microscope. The limy beds differ from the siliceous and argillitic beds mainly in the presence of calcite as the matrix rather than the cryptocrystalline siliceous material.

TABLE 2.-Results of insoluble-residue tests on rock specimens from Chuniksak Formation, Attu

\begin{tabular}{|c|c|c|c|c|c|}
\hline $\begin{array}{c}\text { Labora. } \\
\text { tory } \\
\text { No. }\end{array}$ & Field No. & Rock type & $\begin{array}{l}\text { Weight } \\
\text { percent } \\
\text { insoluble t }\end{array}$ & $\begin{array}{c}\text { Weight } \\
\text { percent } \\
\text { soluble } \\
\mathrm{Fe}^{2} \text { as } \\
\mathrm{Fe}_{2} \mathrm{O}_{3}{ }^{2}\end{array}$ & $\begin{array}{c}\text { Weight } \\
\text { percent } \\
\text { carbonate } \\
\text { by } \\
\text { difference }\end{array}$ \\
\hline
\end{tabular}

Temnac-Abraham Pass

\begin{tabular}{|c|c|c|c|c|c|}
\hline 1 & $49 \mathrm{By} 36$ & Calcareous bed in argillite....... & 42.4 & 0.6 & 57. 0 \\
\hline \multicolumn{6}{|c|}{ Nevidiskov Bay } \\
\hline 2 & $49 \mathrm{P} 23$ & Nodule in argillite. . . . & 24. 4 & 0.2 & 75. 4 \\
\hline-3 & $49 \mathrm{P} 24$ & Sandy bed in argillite..... & 53. 1 & 3. 7 & 43. 2 \\
\hline
\end{tabular}

\begin{tabular}{|c|c|c|c|c|c|}
\hline \multicolumn{6}{|c|}{ Chuniksak Point } \\
\hline 4 & $49 \mathrm{P} 26$ & Sandy marker bed in argillite $\ldots \ldots$ & 66. 7 & 1. 2 & 32. 1 \\
\hline 5 & $49 \mathrm{P} 27 \mathrm{~d}$ & Nodule(?) in argillite & 36. 9 & 2. 4 & 60. 7 \\
\hline 6 & $49 \mathrm{P} 27 \mathrm{e}$ & Argillite & 90.8 & 3. 2 & 6. 0 \\
\hline 7 & $49 \mathrm{P} 27 \mathrm{~g}$ & do & 91. 0 & 4. 0 & 5. 0 \\
\hline 8 & 49P30a & $\ldots$. & 98.1 & 1. 2 & 7 \\
\hline 9 & $49 \mathrm{P} 30 \mathrm{c}$ & Nodule(?) in argillite & 21. 5 & 4. 6 & 73. 9 \\
\hline 10 & $49 \mathrm{P} 30 \mathrm{e}$ & _ do do & 21. 3 & 4. 5 & 74. 2 \\
\hline 11 & $49 \mathrm{P} 30 \mathrm{j}$ & Silicic argillite & 97. 4 & 1. 6 & 1. 0 \\
\hline 12 & $49 \mathrm{P} 36 \mathrm{j}$ & Sandy argillite $\ldots$ & 97. 2 & 1. 1 & 1. 7 \\
\hline 13 & $49 \mathrm{P} 36 \mathrm{k}$ & Calcareous bed in argillite & 55. 0 & 7 & 44. 3 \\
\hline 14 & $\ldots$ & Nodule in argillite & 51. 2 & 4 & 48. 4 \\
\hline 15 & 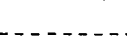 & do & 35. 3 & .4 & 64.3 \\
\hline
\end{tabular}

1 Determined by Ray E. Wilcox using method of McQueen (1931).

2 Determined by Harold Bloom of the U.S. Geol. Survey by method of Sandell (1944, p. 27)

$407-8560-71 \longrightarrow 3$ 
Nodules and concretions are conspicuous in the shore platforms of Chuniksak Point (fig. 108). These nodules are ellipsoidal with long dimensions parallel to the bedding and have flattened bottoms and domed tops. They range in maximum horizontal dimension from less than 1 foot to as much as 10 feet and generally are in preferred stratigraphic zones, although not confined to any one type of surrounding rock.

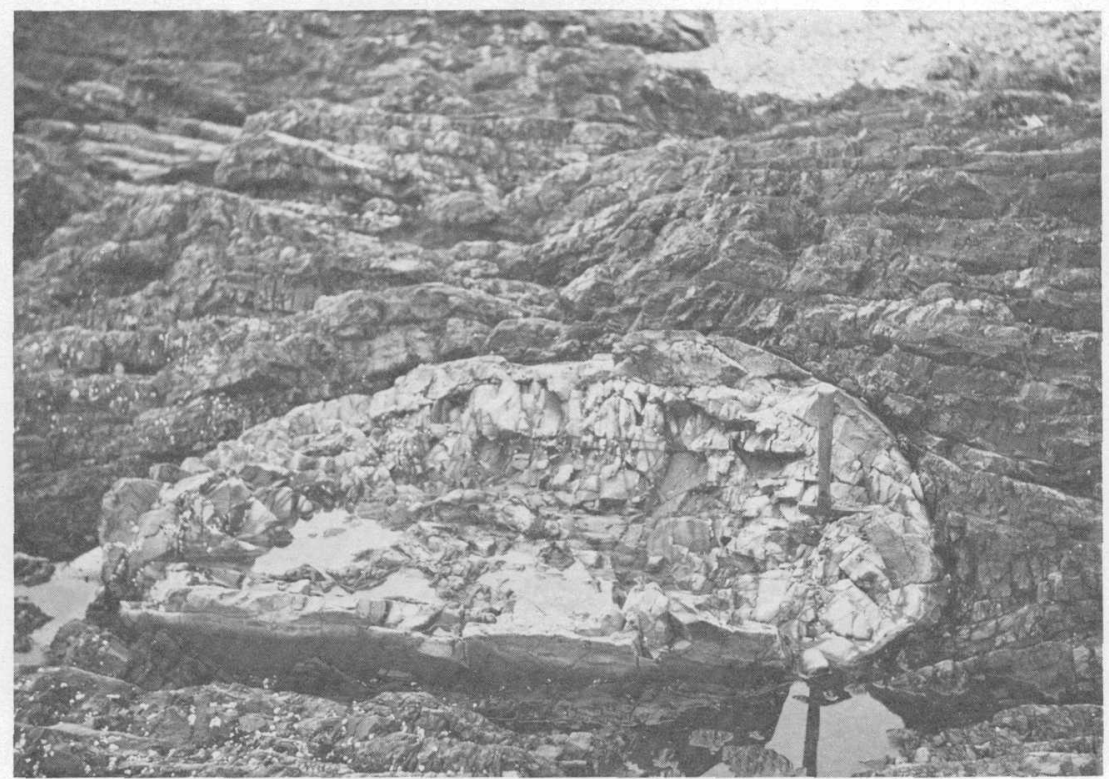

Figure 108,- Limy nodule in Chuniksak Formation, Chunlksak Point, Attu. Long dimension, about 4 feet, is parallel to bedding.

The bedding for the most part divides around the nodule, usually with a marked thinning of beds through a zone which in some places is as much as several tens of feet above and below the nodule. The warping of bedding around the nodules indicates that they were probably formed as primary sedimentary features on the sea floor rather than as replacements of previously existing sediments. Contacts between the nodules and the surrounding rocks are sharp and are accentuated by weathering of the nodules to a buff color. Some nodules have irregularities in coloring and composition, but noticeable bedding and concentric structure are absent. Most of the nodules consist primarily of carbonate, but some contain silica and a few consist of chert. In thin section, the limy nodules are seen to be predominantly fine-grained calcite closely resembling the carbonate 
matrix of the limy rocks, and they contain lenticular and ovoid masses of coarser calcite up to $0.2 \mathrm{~mm}$ diameter and a few scattered fragments of quartz, chert, and feldspar similar to those found in the sedimentary rocks.

Sandy shale, sandstone, and graywacke are the dominant rock types of parts of the formation. They occur in beds ranging in thickness from a few inches to several feet, and they lack the lamination typical of the chert and argillite. Clastic grains are primarily plagioclase, quartz, pyroxene, and chlorite, and the matrix is calcium carbonate or cryptocrystalline silica. The few conglomerate beds contain pebbles of lava.

The following section is an upward continuation of reference section B of the Nevidiskov Formation (p. 730). Like the previous sections, it should be considered illustrative rather than stratigraphically precise. In general, the basal zone of dark sediments overlain by several nodular zones was found to be fairly consistent in the Chuniksak Point area. Near the tip of Chuniksak Point along the west shore of Nevidiskov Bay, the section appears to contain more sandstone and sandy shale in some of the nodular zones than in the following reference section. Small horizontal facies changes involving the various rock types are common.

\section{Reference section of Chuniksak Formation on west side of Nevidiskov Creek valley}

Top of section covered by argillite scree to top of hill. Approximate thickness

Argillite, brown-weathering, silty, with concretions (feet)

Hornblende andesite dike

Argillite, layered, shattered ; possible fault_-_-_-_-_-_-_-_-_-_-_-_-_-_-_ 10

Covered

Argillite with concretions

Hornblende-feldspar porphyry dike

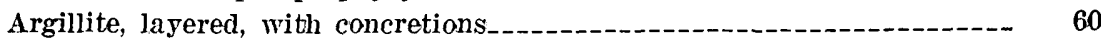

Argillite, dark, banded, with thin siltstone beds-_-_-_-_-_-_-_-_-_-_.- 80

Argillite, layered, with three bands of limy concretions............ 15

Argillite, dark, layered, brown-weathering, with thin siltstone beds_----- 125

Chert, gray to black, layered; bands $1-5 \mathrm{~mm}$ thick with disseminated

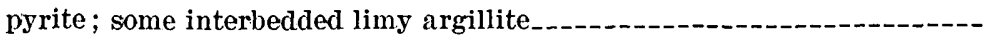

Argillite, dark, layered; weathers brown

Argillite, layered with elongate lenses of calcareous concretions as much as $3 \mathrm{ft}$ long with some 1-in.-thick bands of fissile shale

Siltstone, coarse, with argillite beds in layers $1 / 2-3$ in. thick; weathers

light gray

Argillite, dark, silty

Covered

Fine siltstone to fine sandstone with pyrite streaks 
Reference section of Chuniksak Formation on west side of Nevidiskov Creek valley-Continued

Argillite, layered, limy

Covered. In other areas this zone is primarily black to dark-bluish-gray cherty argillite with a blocky fracture

Argillite, gray to light-brown on weathered surface, gray on fresh surface, layered, silty ; bands up to 2 -in. thick alternating with thinner bands_--

Bottom of section. Conformable contact with graywacke and conglomerate of Nevidiskov Formation.

AGE

- The Chuniksak Formation is the only rock on Attu that yielded an appreciable number of fossils. Mollusks and plants were found on Chuniksak Point in several narrow zones in the concretionary parts of the formation, probably equivalent to those near the middle of the described section. Diatoms and Foraminifera were found scattered sparsely throughout the formation. They show no evidence of having been partially dissolved, and no relics were found in the matrices to suggest that the siliceous or carbonate rocks consist of silica and carbonate recrystallized from diatoms and Foraminifera.

Fragmentary and poorly preserved fossil plants were identified by Roland Brown of the U.S. Geological Survey as Alnus alnifolia (Goppert) Hollick, probably early Tertiary, possibly Eocene in age. Ralph Stewart of the U.S. Geological Survey, who made the identification of a pelecypod as possibly a new species of Lucinoma, commented as follows (written commun., Nov. 2, 1949).

Lucinoma is a fairly common bivalve in late Tertiary faunas and is still living. It has been reported in Pliocene or Miocene strata from Nonya, Japan, and from the Yakataga Formation of southeastern Alaska. The Yakataga Formation is probably of Miocene age. The best Attu specimen is not produced posteriorly and may prove to be a new species.

One poorly preserved gastropod fragment was found with Lucinoma. Stewart tentatively suggested that it is Ancistrolepis, and he wrote:

The genus is now living in the North Pacific and was reported in the Yakataga Formation as Colus rearensis, and it may occur in the Asagai sandstone of Matchgar Sakhalin, which is probably of early Miocene age.

The diatoms were abundant and perhaps furnish the most reliable indication of age. As the enclosing rocks were very difficult to dissolve or disintegrate, most of the diatoms had to be identified in thin section. Determination of these was made by K. E. Lohman of the U.S. Geological Survey, who reported the following diatoms in 12 samples examined. 
Coscinodiscus sp. in seven of the 12 samples.

Triceratium sp. in six of the 12 samples.

Arachnoidiscus sp. in four of the 12 samples.

Rutilaria sp. in two of the 12 samples.

Arachnoidiscus cf. A. oamaruensis Brown in two of the 12 samples.

Coscinodiscus cf. C. radiatus Ehrenberg in one of the 12 samples.

Rhaphoneis cf. R. elegans Pantocsek and Grunow in one of the 12 samples.

Rutilaria epsilon Greville var. longicornis Tempere and Brun in one of the

12 samples.

Stephanopyxis sp. in one of the 12 samples.

Amphera? sp. in one of the 12 samples.

Of the four diatoms identified with fair certainty, Rutilaria epsilon Greville var. longicornis Tempere and Brun is known only from the Miocene; Coscinodiscus cf. C. radiatus ranges through most of the Tertiary and is still represented in living assemblages; Arachnoidiscus cf. A. oamaruensis Brown is known only from Oligocene and Miocene rocks; and Rhaphoneis cf. $R$. elegans, the least certain identification, has been found only in middle Miocene rocks.

One plant species, four diatom species, and one pelecypod genus can hardly be considered a sufficient assemblage for positive dating. A Tertiary age seems assured, and a Miocene age is probable on the basis of two of the species of diatoms and permitted by age range of the other two species of diatoms, the pelecypod, and the gastropod. This is at variance with the tentative assignment of early Tertiary, perhaps Eocene age, made by Brown on the basis of one species of plant.

\section{ORIGIN OF THE NEVIDISKOV AND CHUNIKSAK FORMATIONS}

The detritus which forms the Nevidiskov Formation must have been derived from the basement rocks by subaerial erosion and dumped by streams into marine waters. The lensing and intertonguing of graywacke and conglomerate with argillite and siltstone beds may indicate deltaic conditions. The graywacke consists primarily of rock fragments in a fine-grained sandy to silty matrix, but absence of graded bedding indicates that turbidity currents were not involved in its deposition.

The gradation upward of the Nevidiskov Formation into the much finer grained Chuniksak Formation represents a transition to an episode of fairly uniform quiet marine deposition, perhaps in a slowly subsiding basin with restricted connections to the open sea when there was no great topographic relief in the surrounding land. The excellent bedding, lack of ripple marks, scour, or mud chips, and the small grain size suggest absence of current or wave turbulence. The sparsity and lack of variety of benthic megafauna coupled 
with the presence of authigenic pyrite suggests mildly euxenic conditions. The presence of fossil leaves and pelecypods indicates shallow water and possibly nearness to shore.

\section{CHIRIKOF FORMATION}

The here named Chirikof Formation crops out along the south shore of Chirikof Point, the type locality, and just west of Schuler Beach on the north shore (the latter area is too small to be shown on the geologic map, pl. 80). The thickness of the exposed rocks does not exceed 200 feet, and the stratigraphic relations with other Attu rocks are obscure. Along the south shore, the Chirikof Formation is separated from outcrops of the basement rocks by a gravel beach and a sill or dike of hornblende andesite porphyry, so that nowhere is a stratigraphic contact exposed. However, within a distance of 200 feet across the buried contact, Chirikof sedimentary rocks dip to the south at angles of $55^{\circ}$ to $85^{\circ}$, whereas the basement rocks have very gentle dips to the north. Similarly abrupt differences in attitude between the Chirikof and the basement rocks were noted just west of Schuler Beach, the actual contact being obscured there also. In both places, the Chirikof rocks are probably faulted against the basement rocks, although the possibility of a marked angular unconformity cannot be entirely eliminated. In both areas of outcrop on Chirikof Point the top of the Chirikof Formation is submerged.

The Chirikof Formiwion is made up of boulder conglomerate, pebble conglomerate, coarse sandstone, carbonaceous shale and sandstone, and possibly one lava flow. The boulder conglomerate consists of large rounded boulders in a coarse sandy matrix. The pebble conglomerate is made up of angular to round pebbles of argillite, basalt, chert, and albite granite in a crudely bedded and poorly sorted sandy matrix. The sandstone contains angular to round grains of quartz, plagioclase, argillite, chert, basalt, and carbonaceous fragments cemented by limy, carbonaceous, and siliceous material. Interbedded with the coarse sand are beds of coaly shale with many leaf and stem imprints and a few silicified tree limbs. Pyrite crystals are common in the carbonaceous parts of the formation. Features such as many lenticular beds, crossbedding, cut-and-fill structures, and poor sorting all suggest deposition by streams or, especially for the boulder conglomerate, by waves along a gravel and boulder beach. The lava is an amygdaloidal keratophyric pillow lava containing albite, a little quartz that is apparently secondary, and much secondary calcite and chloritic amygdules. The base of the lava is exposed at only one spot and contains fragments of pebble conglom- 
erate and sandstone. For some of its length, the contact between the lava and the Chirikof rocks is a fault, and for part of its length the contact is below low tide in a narrow slot eroded in the rock bench. The lava flow thus could be interbedded with the Chirikof rocks, or possibly it and the pebble conglomerate at its base could be part of the basement rocks faulted against Chirikof rocks.

Chirikof rocks are cut by a dike of diabase and by an irregular offshoot from the sill of hornblende porphyry.

Age.-Only two types of leaves in the coaly beds were sufficiently preserved for identification. Roland W. Brown of the U.S. Geological Survey identified one as Cercidiphyllum sp. and the other as Alnus Alnifolia (Goppert) Hollick; the latter is the same species that is represented in the Chuniksak Formation. The age of the Chirikof Formation is regarded as middle Tertiary.

\section{MASSACRE BAY FORMATION}

The here named Massacre Bay Formation consists of subaerial coarse sandstone, conglomerate, tuff, and basaltic andesite lava flows deposited unconformably on the basement rocks. Its known outcrops are mainly in the type area near Massacre Bay; on the north side of Lookout Mountain; on the north side and in the center of Peaceful Valley; along the west shore of Massacre Bay, including Loaf Island; and on Chirikof Point east of Alexai Point.

The formation is at least 500 feet thick, and the maximum thickness observed is on McNew Hill, Chirikof Point. No overlying rocks other than Quaternary alluvium and glacial deposits were found, and the original thickness is unknown. Gently eastward dipping basal conglomerates of the Massacre Bay Formation overlie steeply dipping argillite of the basement rocks near Schuler Beach and at the first pass west of Thiel Pass on Chirikof Point.

The thicknesses of the sandstone and roundstone-conglomerate beds range from 1 to 50 feet. The sandstone is well bedded and shows scour features and crossbedding. The conglomerate shows crude bedding and much interlensing of coarse sand and gravel. Pebbles and cobbles are subround to round and consist of diabase, albite granite, basalt, keratophyre, graywacke, argillite, siliceous sedimentary rocks (no doubt derived from the basement rocks), and basaltic andesite porphyry from the volcanic members of the Massacre Bay Formation. In thin section, it can be seen that fragments derived from the basement rocks are rounded to subround, whereas those such as brown hornblende and zoned plagioclase, derived from the basaltic andesite, are angular. 
The lava flows of the Massacre Bay Formation are massive, many have columnar jointing, and pillow structure is absent. The flows weather easily, in some places into marked spheroidal shapes. The fresh lava is dark purple to purplish brown and contains small phenocrysts of olive-tinted plagioclase and black augite or hornblende. Commonly the lava is weathered to grayish green, is somewhat friable, and contains chalky white feldspars, conspicuous black hornblende or augite phenocrysts, and scattered white amygdules of calcite or zeolite. Phenocrysts are abundant and well developed; in some rocks they compose more than half the volume. Plagioclase phenocrysts have oscillatory zoning and internal patchiness, and hornblende phenocrysts are russet brown and have rims of opaque material or of a fine-grained mixture of pyroxene and opaque oxide. Pyroxene phenocrysts are associated with them in some rocks. In these respects, the lavas resemble many lavas in other parts of the Aleutians. (See Coats, 1952, p. 490.) Groundmasses of the lavas are composed of plagioclase, pyroxene, magnetite, cristobalite, tridymite, and zeolites. Hornblende is rarely present in the groundmass.

Specimen 50P286 (table 1), an andesite from Lookout Mountain, contains abundant stubby plagioclase phenocrysts up to $1.3 \mathrm{~mm}$ long, many slightly ragged brown hornblende phenocrysts up to $2 \mathrm{~mm}$ long, scattered grean chlorite pseudomorphs after pyroxene, and angular grains of opaque oxide as much as $0.2 \mathrm{~mm}$ in diameter. The plagioclase phenocrysts are labradorite-andesine with moderate oscillatory zoning, and the more sodic compositions are in the outer parts. Some of the hornblende phenocrysts show a slight zoning, and their pleochroism is russet to yellow brown. Measured optic angles of these hornblendes are negative and range from $67^{\circ}$ to $74^{\circ}$, and $\mathrm{Z}: c$ is about $8^{\circ}$. The groundmass contains plagioclase, clinopyroxene, magnetite, and a few pleochroic yellow apatite crystals set in a green chloritic base with grains and irregular masses of cristobalite.

Specimen 50P212, another basaltic andesite from Lookont Mountain, has abundant phenocrysts of clouded labradorite-andesine with oscillatory zoning, clinopyroxene, scattered chlorite pseudomorphs after orthopyroxene, scattered crystals of opaque oxide, and a few ragged relics of brown hornblende, now mostly fine opaque oxide. In another specimen from Lookout Mountain (50P211), only rare opaque relics reveal the former presence of an amphibole, whereas fresh clinopyroxene is abundant and fresh orthopyroxene phenocrysts are common. Zoned labradorite-andesine phenocrysts are numerous. The groundmasses of both specimens 211 and 212 contain much interstitial material of extreme negative relief, probably cristobalite or tridymite.

Many of the andesite flows of the Massacre Bay Formation on Chirikof Point contain few phenocrysts of pyroxene and abundant hornblende. An analyzed sample from these flows, 50P373, has opaque black-rimmed hornblende pseudomorphs filled with chlorite, leucoxene, and carbonate. The stubby calcic plagioclase phenocrysts are patchily replaced by carbonate, and a few square-outlined masses 
of carbonate suggest basal sections of original pyroxene. Microphenocrysts of blocky andesine and labradorite are set in a matrix of more sodic plagioclase, quartz (?), and fine opaque oxide. Specimen 50P369, another andesite from Chirikof Point, also contains abundant opaquerimmed relics of hornblende but no pyroxene phenocrysts. Both plagioclase phenocrysts and groundmass microphenocrysts are patchily altered to sodic plagioclase and carbonate. Abundant tiny ragged rods and needles of opaque brown material appear to be relics of hornblende microphenocrysts. Much of the remaining groundmass material is oligoclase and quartz, apparently secondary.

Coarse beds of volcanic breccia and tuff as much as 75 feet thick are interlayered with the basaltic andesite flows in the Massacre Bay Formation. The tuff beds contain lapilli and blocks of basaltic andesite in which the hornblende is green, not brown as in the lavas. Flow breccias, consisting primarily of angular basaltic andesite boulders, are prominent on McNew Hill and Loaf Island. On the north side of Lookout Mountain many gabbro boulders, some as large as 6 feet in diameter, are mixed with basaltic andesitic blocks in a matrix rich in hornblende, weathered feldspar, argillite pebbles, and carbonized wood. These are probably volcanic mudflows or avalanches. Many of the tuffaceous beds are mixtures of subround detrital rock fragments, angular volcanic breccia fragments, bombs, and ash in matrices of coarse sand, coarse ash, and green chloritic material.

A small patch of conglomerate of hornblende-bearing lava cobbles on the rock platform on the east shore of the West Arm of Nevidiskov Bay dips westward at a low angle and unconformably overlies argillites which strike generally eastward and dip steeply. This conglomerate is tentatively mapped as Massacre Bay Formation because of its green colors (in contrast to the red of the Faneto Formation) and the presence of fragments of andesite rich in common hornblende or oxyhornblende.

Age and depositional environment.-Lack of fossils precludes dating of the Massacre Bay Formation. From the composition of the pebbles in conglomerate and the unconformable relationship of the formation with the basement rocks, it is evident that the Massacre Bay rocks were deposited after intrusion of the gabbroic and diabasic rocks and the albite granite, and after deformation and uplift of the basement rocks. Inasmuch as gabbro and diabase cut the Chuniksak Formation, the Massacre Bay Formation must be younger than Miocene, and glacial features indicate that it is older than the last Pleistocene glaciation. A late Tertiary or early Pleistocene age is probable. 
The lava flows, stream deposits, land mudflows, and volcanic avalanches of the Massacre Bay Formation were deposited on a surface of considerable relief cut in the basement rocks. Rounded pebbles and cobbles derived from the basement rocks were mixed with pyroclastic material from contemporaneous eruptions. The presence of carbonized wood indicates a forested area.

\section{FANETO FORMATION}

The here named Faneto Formation includes at least 1,500 feet of coarse red clastics. In the area northwest of Holtz Bay the Faneto clastic materials rest on the Chuniksak Formation, apparently along an angular unconformity. No actual contacts were seen, but along the beach and in the steep sea cliffs the Chuniksak beds are much contorted and have steep to vertical dips, whereas above the cliffs and just inland the Faneto beds have moderate to gentle northerly dips and are cut by normal faults but are not greatly contorted. Furthermore, the Faneto Formation contains a high percentage of pebbles of argillite resembling the Chuniksak argillite. In the vicinity of Faneto Hill, 4 miles west of West Arm Holtz Bay, the type locality, the formation rests on deformed albitized and propyllitized lavas and interbedded sediments of the basement rocks. The Faneto beds thus must overlap the Chuniksak beds onto the basement rocks, although this overlap was not actually traced in the field.

The subaerial Faneto Formation consists of pebble, cobble, and boulder conglomerates, coarse sandstone, coarse graywacke, and thin argillite lenses. Beds are predominantly red and greenish red but a few are gray. Pebbles and cobbles are round to subangular and composed of lava, argillite, gabbro, and diabase. Sorting is poor and bedding is generally coarse with much lensing and crossbedding and many cut-and-fill structures, indicating deposition by streams. The basal beds are the coarsest, and the beds become finer grained upward in the formation. The red color partly results from abundance of pebbles of red argillite; but some of the lava pebbles are red also, and in one place the basal conglomerate rests on a reddish lava. Thus, much of the redness may be attributed to erosion of the red basaltic lavas. Typical Faneto sandstone is seen under the microscope to consist of angular to subround grains of argillite, basalt, keratophyre, albite granite, quartz, weathered plagioclase, pyroxene, hornblende, chlorite, epidote, and opaque oxides, mostly magnetite.

Age and depositional environment.-The age of the Faneto Forma. tion is not established definitely, because fossils are lacking. It is younger than the basement rocks and the Chuniksak Formation and younger than the diabase and albite granite. It was deeply eroded 
by glaciation and thus is at least older than the last glaciation. Its age relation to the Massacre Bay Formation is obscure, but the content of hornblende in many of these clastics implies post- or syn-Massacre Bay age. Thus, the Faneto Formation is late Tertiary or early Pleistocene in age, and perhaps the youngest preglacial deposit on the island.

The Faneto rocks are presumed to have been deposited by heavily loaded streams on a subaerial terrain. The constituent fragments were derived from the basement rocks, and the Chuniksak and perhaps Massacre Bay Formations. The redness of the formation perhaps reflects weathering of the fragments of the older rocks it contains.

\section{SURFICIAL DEPOSITS}

Here only a brief review will be given of the deposits of turf mantle, alluvium, till, dune, and beach material. A fuller description and discussion of surficial deposits is given by J. P. Schafer in the section, "Surficial Geology of the Near Islands."

Much of Attu Island is covered by a mantle of tundralike turf characteristic of the Aleutian Islands and part of the Alaskan mainland (Kellogg and Nygard, 1951). The turf is only a few feet thick over most of the area, and it is absent on many glaciated knobs. Where rocks are easily broken by frost action, the turf mantle is well developed, and on the many steep slopes the turf mantle has crept downhill, producing low terraces or lobes.

The glacial till deposits are shown on the geologic map (pl. 80) principally only in areas that were visited in the field, and they are divided as far as practical into ground-moraine deposits and terminal- or lateral-moraine deposits. Many areas of thin ground moraine are not shown. Terminal and lateral moraines are very limited in extent and consist mainly of material deposited during the late minor readvances of ice which scarcely reached beyond the cirque mouths. Such small morainal features are especially common in the high mountains just north of Etienne Bay. Two end moraines at some distance from the cirque area, however, are found in Addison Creek valley about 2 miles above its mouth at Holtz Bay. Although such end moraines may exist in some of the other long alluviated valleys, they were not recognized. The terminal moraines of the main glaciations are offshore, for example in Massacre Bay (Scruton, 1953).

Alluvial fill, some of it no doubt outwash material from receding mountain glaciers, occupies the major valleys. An especially broad valley fill is that of the Temnac River; it extends some 5 miles 
upstream from the river mouth and has a gradient of about 40 feet per mile. As in most other Attu valleys, broad low coalescing alluvial fans occur along the bases of the walls of Temnac Valley, in places crowding the main stream to the opposite wall. Most alluvial fills are continuous to the ocean, but a notable exception is that of Winter Lake on Diehm Creek, perched some 800 feet above the creek mouth at Steller Cove.

Sand beaches are common at the heads of the bays and coves, and the more prominent ones are shown on the geologic map (pl. 80), which does not distinguish, however, between present-day beaches and old raised beaches. Commonly, a narrow sand beach lies between the tide-washed rock bench and the base of the shore cliff or slope. Material of the beaches is generally clean sand and rounded pebbles. Boulder beaches, not shown on the map, are present at a few places. Raised beaches are spectacularly displayed at the heads of some bays, such as Etienne and Holtz Bays, and in some places they indicate at least two stands of the strand line above that of the present. The long stretch of raised beaches between Steller Cove and Earle Cove on the north shore suggests more uplift of this area than of the rest of the island, and the low fault scarps across these beaches indicate that differential movements have continued to very recent time.

\section{INTRUSIVE ROGKS}

Diabase, gabbro, albite granite, hornblende andesite, and quart\% keratophyre are the main types of intrusive rocks on Attu. A common contact effect is the albitization of tuffs and sediments around some large igneous masses, which themselves may be albitized to varying degrees. The following discussion gives the geologic setting and brief descriptions of these igneous rocks.

\section{DIABASE AND GABBRO}

Sills and dikes of diabase (in some places more gabbroic than diabasic in texture) with no apparent orderly pattern of distribution make up about two-thirds of the intrusive rocks of Attu. Only the larger bodies are shown on the map (pl. 80); many additional dikes and sills are too small to be shown at the map scale. The apparent lack of diabase on the map in central and western Attu may be misleading because this area was mapped only in roughest reconnaissance.

The rocks in this group include not only the thin mafic dikes and sills with true ophitic texture but also the rocks of larger and generally less regular mafic intrusive bodies which, with or without ophitic texture, are part of the diabase series. Both in detail and 
in gross geologic setting the suite shows many similarities to the "tholeiite quartz-diabase association" reviewed by Turner and Verhoogen (1951, p. 177-188). The plagioclase is progressively zoned from as much as $\mathrm{An}_{70}$ at the centers to $\mathrm{An}_{30}$ or lower at the edges. In the quartz diabase the quartz is generally interstitial and graphically intergrown with alkali feldspar, which is in crystallographic continuity with plagioclase. Biotite, chlorite, sphene, and apatite, where present, are usually associated with the interstitial quartz. Pyroxene is invariably present and was found to be augitic rather than pigeonitic in aII examples for which optic angles were determined. Uralite is a common alteration product of the pyroxene, and, in turn, chlorite has developed from some uralite. In a few rocks bowlingitelike masses, which resemble pseudomorphs after olivine, are present.

Following are brief petrographic descriptions of individual diabase specimens of Attu. Further descriptions are given in the section on Agattu Island, the diabases of which show variations similar to those of diabases of Attu.

Specimen 49W21a (table 1) is from a diabase sill at the mouth of Chuniksak Creek on the south shore of Attu. It is coarsely ophitic and contains 59 percent plagioclase, 17 percent augite, 20 percent chlorite (including some bowlingite and a little amphibole and biotite), and 4 percent opaque oxide by volume. The plagioclase shows progressive zoning from about $\mathrm{An}_{65}$ at the centers to as low as $\mathrm{An}_{30}$ at the edges of some crystals and is cut by stringers of chloritic material. Augite crystals show optic angles $(+) 2 \mathrm{~V}=50^{\circ} \pm 2^{\circ}$ and an index $n \mathrm{Y}=$ $1.692 \pm 0.003$, implying a composition near $\mathrm{Ca}_{41} \mathrm{Mg}_{40} \mathrm{Fe}_{18}$.

Specimen 49 W26 (table 1 ) is a diabase from the central part of a sill at the U.S. Coast and Geodetic Survey triangulation station DIVE. This is possibly the same sill as that from which 49 W21a was taken. The rock is coarsely ophitic and contains 48 percent plagioclase, 13 percent fresh augite, 3 percent amphibole and biotite, 32 percent saponitic material (altered glass and olivine?), 3 percent opaque oxide, and about 1 percent of prehnite, sphene, and apatite. The plagioclase rims are clear albite-oligoclase, but the bulk of the plagioclase crystals is cloudy saussurite. The few remnants of labradorite $\left(\mathrm{An}_{50}\right)$ stand out in bold contrast against the saussuritized plagioclase. Augite crystals have (+) $2 \mathrm{~V}=51^{\circ}-55^{\circ}$ and $n \mathrm{Y}=1.698 \pm 0.003$, implying a composition near $\mathrm{Ca}_{43} \mathrm{Mg}_{35} \mathrm{Fe}_{22}$.

Specimen $49 P 53$ (table 1), from an intrusive above Sonoma Beach, Temnac Bay, Attu, is a quartz gabbro having a hypidiomorphic texture. A modal analysis shows 58 percent plagioclase, 19 percent augite, 12 percent chlorite material, 10 percent quartz, and about 1 percent opaque oxide and apatite by volume. The plagioclase is commonly zoned from near $\mathrm{An}_{60}$ at the center to $\mathrm{An}_{\mathbf{9 5}}$ near the edge, then suddenly to as low as $\mathrm{An}_{15}$ in the rim. The augite, showing some diallage structure and embayment by uralite, has $(+) 2 \mathrm{~V}=50^{\circ}$ to $55^{\circ}$ and $n \mathrm{Y}=1.699$ \pm 0.003 , implying a composition near $\mathrm{Ca}_{42} \mathrm{Mg}_{34} \mathrm{Fe}_{24}$. The quartz occurs in the mesostasis intergrown with sodic plagioclase.

Specimen 50P295 (table 1) is a partly albitized quartz-diabase from the quarry at Casco Bay, Attu. It has an ophitic texture and contains 65 percent plagioclase, 15 percent augite, 12 percent chlorite (including a little biotite and amphibole), 
3 percent opaque oxide crystals, and about 5 percent interstitial quartz. The plagioclase is mostly cloudy albite in which only scattered islands of original labradorite $\left(A n_{65-55}\right)$ remain. Augite is partly altered to uralite but where fresh has $(+) 2 \mathrm{~V}=51^{\circ}$ to $53^{\circ}$ and $n \mathrm{Y}=1.695 \pm 0.003$, implying compositions near $\mathrm{Ca}_{42} \mathrm{Mg}_{35} \mathrm{Fe}_{20}$.

Contact alteration effects of the diabase are apparent locally. A common effect on basaltic tuff's is conversion of plagioclase to albite, and then of pyroxene to amphibole. Examples of mild albitization and amphibolitization of basic tuffs are described with the diabases of Agattu.

Age.-Intrusion of diabase and gabbro clearly antedates the Massacre Bay and Faneto Formations. Many dikes of diabase intrude the Chuniksak and Chirikof Formations; thus, these are not older than Miocene. Most of the diabase and gabbro, however, cuts the basement rock in areas where younger rocks are missing, making it possible that some is older than Miocene and perhaps is the intrusive equivalent of the submarine eruptions of basalt of the basement rocks.

\section{ALBITE GRANITE}

Albite granite occurs as irregular masses in the Steller Cove area (possibly the locality referred to by Kondo, 1931) and as a small stocklike mass east of Mikhail Point; all masses are surrounded by basement rocks. In the Steller Cove area, the granites cut some gabbroic intrusive rocks and are cut in turn by diabase and keratophyric dikes. In hand specimens the albite granites are variously gray, pale pink, or purplish, and some contain euhedral graygreen feldspars up to $5 \mathrm{~mm}$ long. Grain size may vary widely even in the same outcrop, and in some parts of an outcrop the rock may be microgranitic and have phenocrysts that are irregular knots.

A halo, as much as 2 miles wide, of albitized and silicified basement rocks surrounds the albite granite masses in the Steller Cove area. These altered country rocks, which consist mostly of conglomerates and subordinately of argillites and volcanic rocks, are dense and gray to pale blue. In outcrop the primary sedimentary or volcanic fabrics are cut by light-colored veinlets. Albite porphyroblasts up to $5 \mathrm{~mm}$ in length are scattered throughout, and many extend across contacts between pebbles and matrix. Thin sections show that the chief constituents of these altered rocks are albite and quartz. Pyroxene, hornblende, chlorite, epidote, sphene, and magnetite are generally rare, except in relics of basalt fragments, where the original basaltic texture is retained in spite of drastic changes in mineralogical composition. 
Specimen 50P302 (table 1), an albite granite from the point between Blonde and Brunette Coves, Steller Cove, is pale pinkish purple in hand specimen and contains euhedral coarse green-gray feldspar crystals up to $5 \mathrm{~mm}$ in length. In thin section the texture is hypautomorphic granular with much micrographic and myrmekitic material. Stubby euhedral to subhedral cloudy albite crystals predominate, commonly in crystallographic continuity with the albite of albitequartz micrographic intergrowths. Some myrmekitic veinlets cut across albite and lie along noncrystallographic grain boundaries. The cloudy and dusty plagioclase ranges from $\mathrm{An}_{3}$ to $\mathrm{An}_{8}$, based on extinction angles, whereas the rare clear patches are oligoclase. Multiple twinning on the albite law is common, frequently accompanied by subordinate twinning on the pericline (or acline) law. The outer parts of most albite crystals are untwinned. About one-fifth of the rock is clear quartz, both as a component of the micropegmatite and as individual anhedral grains. Amphibole is scattered through the rock as ragged crystals, only a few of which are euhedral and many of which enclose grains of quartz, albite, epidote, and magnetite. The main parts of the amphibole have brown to yellow pleochroism, positive elongation, and a moderate extinction angle. This material grades outward into thin ragged rims, and extensions have blue-violet to greenblue pleochroism, negative elongation, and low extinction angle, indicating a sodic variety of amphibole, perhaps riebeckite. Magnetite, pyrite, epidote, titanite, and chlorite are accessories. Chemically the rock is notable for its soda content, 7.32 percent, highest of any of the analyzed Near Islands rocks, and for its low Niggli value, $k=0.157$.

Other specimens of albite granite, in comparison with the one described above, contain as much as 5 percent of common green hornblende as ragged crystals lacking the sodic rims and extensions. Some have as much as 5 percent epidote which, with calcite and chlorite, may give the rock a more altered appearance than that of 50P302. Generally the rocks with finer texture seem to have less quartz. Two albitite "dikes" on the point west of Brunette Cove are no doubt closely related to the albite granites.

Age.-The oldest albite granite is seen as blocks in keratophyric tuffs in the basement rocks. The main intrusions of granite cut the basement rocks, and their encircling halos of alteration have affected some gabbroic rocks. Also, diabase dikes (too narrow to show on the map) cut some of the albite granite. Boulders of albite granite occur in the Chirikof Formation. Thus, the intrusions of albite granite may have taken place over a span of time, but generally before Miocene.

\section{QUARTZ KERATOPHYRE PORPHYRY}

Several dikes of quartz keratophyre occur in widely separated parts of Attu. They are generally alike in texture and mineralogy but not necessarily in age. One dike cuts the basement rocks on the tip of Temnac Point about 2 miles west of the keratophyric flows on Murder Point. Another dike with prominent flow lines (fig. 109) cuts albite granite in the Steller Cove area and is in turn cut by diabase; 
this dike appears to be associated with the albite granite complex. A third keratophyric dike cuts the Faneto Formation and thus is comparatively young. In hand specimen the quartz keratophyres show chalky white euhedral crystals of feldspar and smaller glassy grains of quartz in an aphanitic bluish-gray to light-gray groundmass. In thin section, the principal minerals are seen to be albite and quartz in a groundmass consisting of a cloudy diffuse mosaic of quartz and albite with a few shreds and grains of calcite, epidote, chlorite, magnetite, and apatite.

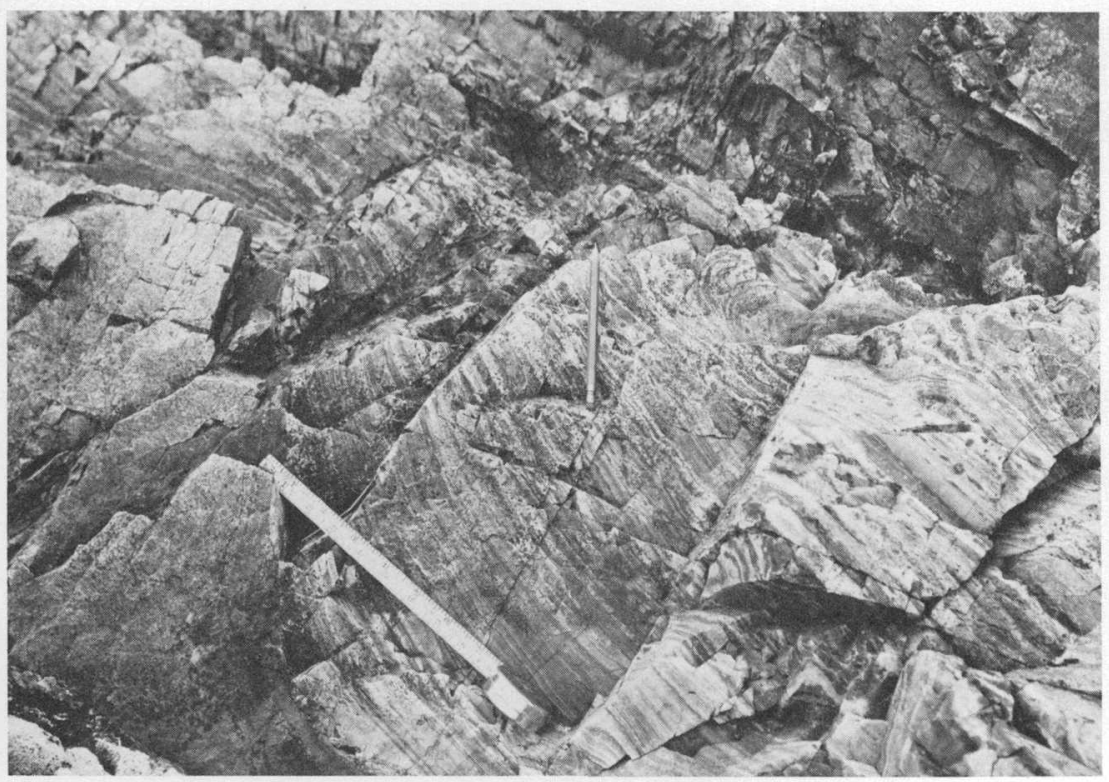

Figure 109.-Quartz keratophyre dike, between Blonde and Brunette Coves, Steller Cove, Attu, showing flow lines.

Specimen 50P312 (table 1) is a porphyritic quartz keratophyre from the dike cutting Faneto Hill. Phenocrysts include albite, both as single euhedral crystals as much as $2 \mathrm{~mm}$ in diameter and as clusters. Rounded and embayed quartz grains up to $1 \mathrm{~mm}$ diameter and rare euhedral opaque oxide crystals up to $0.3 \mathrm{~mm}$ diameter are associated with the albite. The albite phenocrysts are flecked with sericite, and the central parts of some are a matted intergrowth of sericite and calcite. Polysynthetic twins on the albite law and on the pericline or acline law are well developed. The groundmass is a felt of fine-grained albite and quartz (in places granophyric) through which are scattered flecks of sericite as in the albite phenocrysts. Leucoxene, probably after ilmenite and sphene, also is scattered through the groundmass, as are independent minute crystals of opaque oxide. Apatite and zircon(?) are additional accessory minerals. The sericite would account for a large part of the potash shown in the chemical analyses (2.88 percent), and the calcite would account for some of the lime (1.14 percent). 
Widely separated areas of Attu contain hornblende andesite and dacite dikes and stocks. Among these are two stocks and several dikes that cut the basement rocks on Chirikof Point, dikes that cut the basement rocks east of Abraham Bay (fig. 110) and Steller Cove, a swarm of dikes that intrude the Chuniksak Formation in the Chuniksak Point area, and a dike that cuts the halo around the albite granite in the Steller Cove area. No hornblende andesite or dacite intrusives were found in the very brief reconnaissance of the far western part of the island. Many of the hornblende-bearing intrusives are alined approximately east-west, especially on Chirikof Point and in the Chuniksak Point area. This alinement parallels a broad zone of east-west normal faults, some of them postglacial, and of spotty pyrite mineralization that extends from Abraham Bay nearly to the end of Chirikof Point. Hornblende-bearing dikes away from this fault zone, such as the one on Chuniksak Point and the one in the Steller Cove area, are oriented roughly north-south.

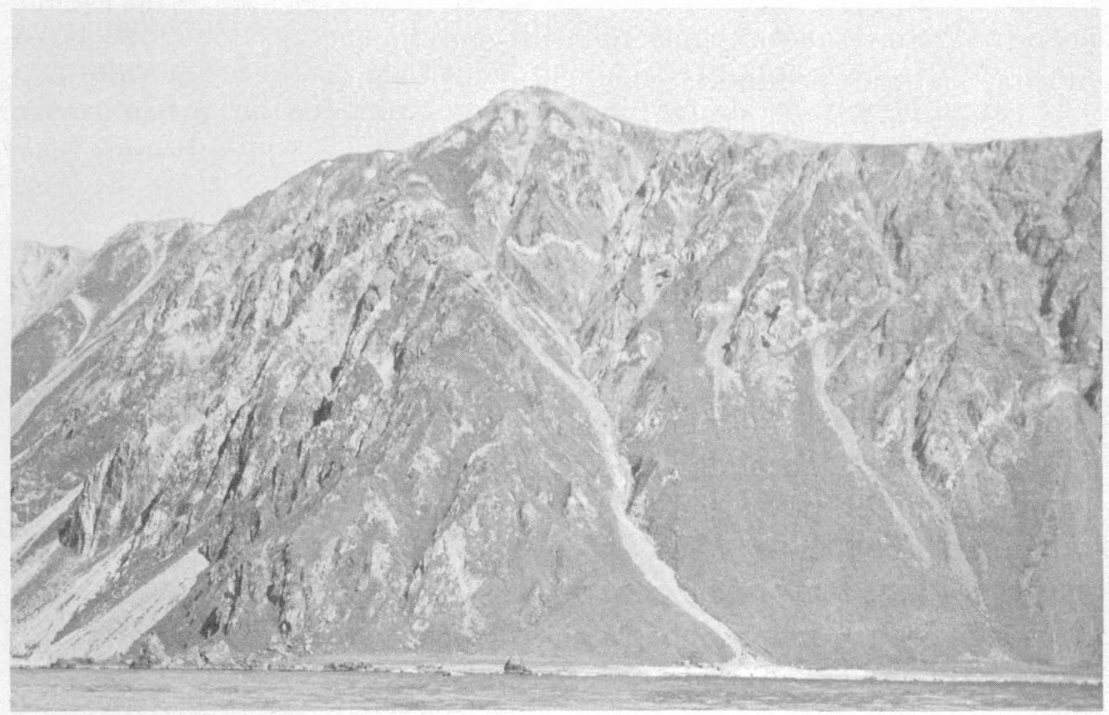

Figure 110.-Andesitic and dacitic dikes intruding conglomerates of the basement rocks, east wall of Abraham Bay, Attu. Dikes are light-colored zones extending generally upward to right.

The hornblende andesite and dacite of the dikes consists chiefly of plagioclase and hornblende, in some places accompanied by pyroxene both as phenocrysts and in the groundmass. In spite of varying degrees of alteration, the dikes have a number of characteristics in 
common. In most of them, plagioclase phenocrysts are zoned with a labradorite interior and an andesine exterior. In some the zoning is gradational, and in others, oscillatory. Most plagioclase phenocrysts are fresh, but some are veined and embayed by albite. A thin rim of more calcic feldspar is typical of feldspar phenocrysts and of some microphenocrysts in the groundmass. In some of the rocks, hornblende occurs as zoned ragged phenocrysts having a pale-green exterior and a dark-green interior. Groundmasses consist of small plagioclase and hornblende microphenocrysts and accessory minerals set in a mosaic of dusty and cloudy sodic plagioclase and quartz.

Specimen 49W36 (table 1) was collected from the dike at the contact between the Chirikof Formation and the basement rocks along the south shore of Chirikof Point. The hand specimen shows black hornblende laths and stubby chalkywhite feldspar phenocrysts in a pale-grayish-green aphanitic groundmass. In thin section the principal phenocryst mineral is seen to be euhedral labradorite, most of which shows both oscillatory and gradational zoning from a labradorite interior to more sodic exterior. Many of the gradationally zoned crystals are veined and embayed with albite, which in some crystals isolates islands of original calcic plagioclase. Around the edges of some phenocrysts is a discontinuous narrow band of plagioclase more calcic than that of the body of the crystal. The second most abundant phenocrysts are green hornblende-ragged remnants of apparently once euhedral crystals. The hornblende shows olive-green to pale yellow-green pleochroism; a few crystals show irregular color zoning, having a pale-green outside band surrounding a darker green interior. Extinction angle $\mathrm{Z}: c$ is about $15^{\circ}$. Chlorite- and epidote-filled euhedral pseudomorphs after pyroxene (orthopyroxene?) are common, and a few phenocrysts of clinopyroxene and opaque oxide are present. The groundmass contains many small tabular and lathlike crystals of labradorite, either gradationally or sharply zoned, with a more calcic interior and a sodic exterior. Some of the crystals are partly altered to albite. Small ragged shreds and rods of very pale green to colorless hornblende; small grains and rods of clinopyroxene; chlorite; and small crystals of apatite, titanite, and magnetite are also present, set in a diffuse cloudy mosaic of quartz and albite-oligoclase.

Specimen $49 \mathrm{~W} 22$ was collected from a dike that cuts the Chuniksak Formation on the ridge northwest of the head of West Arm, Nevidiskov Bay. The hand specimen has prominent white feldspar phenocrysts and less prominent black crystals of hornblende in a brown groundmass. Microscopic examination shows the feldspar phenocrysts to be of two distinct types: one clear labradorite, the other rounded turbid sodic plagioclase. The first type occurs as stubby crystals, oscillatory zoned from $\mathrm{An}_{65}$ to $\mathrm{An}_{45}$, closely resembling the oscillatory zoned crystals in specimen 49W36. Some of the edges of the clear crystals are slightly corroded, and a few have a thin discontinuous rim of plagioclase of composition about $\mathrm{An}_{80}$. The other type of phenocryst is subhedral and consists of thoroughly altered gradationally zoned feldspar crowded with flecks, grains, and shreds of calcite, chlorite, amphibole, and magnetite. Alined along cleavage planes are small irregular strings of isotropic material suggesting glass or fritting. The feldspar containing these inclusions has low index and relief and is probably albite, although it is so obscured by inclusions that identification is not certain. Around the edges of these highly altered crystals is a rather continuous thin band of more calcic plagioclase with a composition of about $\mathrm{An}_{\theta c}$, 
similar to that of the rims around the clearer plagioclase crystals and to that of the rims around some of the feldspar phenocrysts in specimen 49W36. The hornblende phenocrysts are ragged euhedral crystals pleochroic in pale yellowish green and olive green; some have a darker green interior sharply set off from a pale green outer rim. In addition to the plagioclase and hornblende, several rounded grains of titanite and apatite as much as $0.4 \mathrm{~mm}$ in diameter were noted. Groundmass crystals of plagioclase and hornblende resemble closely the crystals of the same minerals in specimen $49 \mathrm{~W} 36$, but hornblende shreds are considerably more abundant. Accessory minerals in the groundmass include calcite, apatite, and magnetite. As in the other types of hornblende andesite, these groundmass crystal grains are set in a cloudy mosaic of quartz and albite.

Specimen 50Sn52 is from the narrow dike that cuts the halo around the albitegranite in the Steller Cove area. The hand specimen shows abundant black laths of hornblende, some more than 1 centimeter long, in a grayish-brown aphanitic groundmass. The thin section reveals several differences from the other hornblende porphyries. Feldspar phenocrysts are albite ranging in composition from $\mathrm{An}_{0}$ to $\mathrm{An}_{10}$, have irregular corroded outlines, and contain scattered splotches of epidote, chlorite, and amphibole. Discontinuously surrounding the albite are narrow rims of more calcic feldspar with a composition from $\mathrm{An}_{40}$ to $\mathrm{An}_{65}$. The hornblende phenocrysts are euhedral and have many sharp crystal boundaries and slightly rounded corners, but their edges are not as ragged as those of the hornblende phenocrysts in the other rocks. Pleochroism is pronounced, the color ranging from a pale yellowish green to a pale grass green. Many grains are distinctly zoned, having a light-green interior and thin concentric layers of even lighter green and a slightly darker green outermost rim. Extinction angles of adjacent zones may differ by as much as $4^{\circ}$. The tabular and lathlike plagioclase crystals of the groundmass are much more calcic than the phenocrysts ; their composition is about the same as that of the plagioclase rims around the phenocrysts. The groundmass contains calcite, magnetite, and moderate amounts of hornblende. Again the diffuse mosaic of quartz and albite is present in the background.

Age.-The hornblende andesite and dacite dikes are clearly younger than the Chuniksak Formation and, hence, must be late Tertiary or early Pleistocene in age. The possibility that they are also younger than the diabase-albite granite rocks is suggested by the fact that the hornblende-bearing dike in the Steller Cove area is not albitized, as are the other rocks in the aureole. Similarities in mineralogy between the hornblende-bearing dikes and the hornblende-bearing lavas of the Massacre Bay Formation suggest that the two may be contemporaneous.

\section{PYRITE MINERALIZATION}

Conspicuous red to reddish-brown zones of pyrite mineralization occur in all types of rock and are of all sizes, ranging from small isolated pods a few feet in diameter to broad areas 2-3 miles long and 1 mile wide. Conspicuous but not universal in many areas is a roughly eastward trend of single large elongate zones or of alinement of small zones. This trend parallels that of many of the hornblende- 
bearing dikes and of many of the more conspicuous faults, some of which are postglacial. The pyrite zones, however, are not restrictedly associated with the hornblende-bearing rocks nor with discernible east-west faults.

Mineralization has not been confined to one single episode, for pyritized pebbles in unmineralized matrix were found in many conglomerates ranging from those of the basement rocks to those in the Massacre Bay Formation. Broad mineralized zones are conspicuous in the formations older than the Massacre Bay Formation; two prominent zones are associated with swarms of hornblendebearing dikes at Abraham Bay and Chirikof Point. Here some of the dike rock is mineralized to some extent, and some is unaffected. At Lookout Mountain, mineralized basement rock is overlain unconformably by unmineralized clastic rocks of the Massacre Bay Formation. However, there is pyrite mineralization in some rocks younger than the Massacre Bay. One zone just west of Kresta Point, in fact, cuts across unconsolidated gravels on an old raised beach. No doubt there have been a number of episodes of pyrite mineralization during as much geologic time as is represented by the rocks of Attu, from the oldest to the postglacial sediments.

The mineralization has several facies and considerable variation in intensity. One facies, prominent on Chirikof Point and involving both the basaltic andesite flows and the hornblende-bearing intrusives, is associated with much albitization and silicification, growth of much epidote and chlorite, and lesser amounts of pyrite than are found in other types. A second type, found east of Abraham Bay, is rich in introduced pyrite, calcite, albite, and zeolite and forms many chalky white veinlets and white patches, which in many zones give the host rock a claylike appearance where red iron stain is absent. Base metal sulfides other than pyrite are rare in the mineralized zones. A few crystals of galena and chalcopyrite were noted in veinlets, and laboratory tests of altered material from Chirikof Point indicated only traces of lead and copper.

\section{STRUCTURE}

The intricate faults and scarcity of persistent marker beds in the strata of Attu. Island handicap any detailed exposition of the structure of the island or reconstruction of the disturbed beds. Most of the faults mapped are normal, and many probably have large components of strike-slip movement. Direct evidence of thrust faulting was not found. The abundant normal faults, together with innumerable joints, divide the island into a plexus of individual 
blocks, which during orogeny no doubt moved somewhat independently of each other. Folds are mostly broad and open and are subordinated to the faults.

The geologic map of Attu, plate 80, shows dips and strikes, and also the more prominent faults located in the field. Most dips in the basement rocks are northward, and many exceed $30^{\circ}$. Those of the Chuniksak Formation are southward on the south shore, where it forms a shallow syncline, and northward on the north shore north of Holtz Bay. The Faneto Formation appears generally to dip northward in its limited areas of outcrop. With the exception of the Chuniksak Point shallow syncline, no major folded structures were found in the course of the reconnaissance mapping. The dips of the Chuniksak and Faneto Formations suggest, however, that the island is a broad anticline with an east-west-trending axis.

The area of Casco Point and Lookout Mountain overlooking Massacre Bay was examined in more detail than the rest of the island, and the picture of structural complexity obtained there probably typifies much of the island. In a 1,300-foot stretch of bare rock bench along the southeast shore of Casco Point (fig. 111), tuffaceous rocks strike about N. $70^{\circ}-80^{\circ} \mathrm{E}$. and dip $25^{\circ}-35^{\circ} \mathrm{N}$. and are conformable with basaltic massive lavas and pillow lavas. (See description of lavas of the basement rocks, p. 719.) On this wavecleaned rock bench, offset of the sedimentary contacts, and especially of several distinctive thin beds, was easily detected. Unfortunately a unique solution of the total differential movement is prevented by the lack of distinctive crosscutting units such as dikes.

In the area of figure 111 a major steep fault strikes southwestward from the northeastern corner and loses its identity in the central part. If all the movement were vertical, the eastern block may have risen about 150 feet, or if all horizontal, it may have slid some 350 feet northeastward along the strike of the fault. These faults on Casco Point are perhaps part of the same northeasterly trending system that cuts across the base of Chirikof Point.

Similar sequences of sedimentary rocks interbedded with petrographically similar lavas, which also dip about $30^{\circ} \mathrm{N}$., occur on the Weston Mountains 2 miles west of Casco Point. In the saddle between Weston and Lookout Mountains they are cut off on the north by a prominent fault zone trending eastward directly toward the faulted neck at the base of Casco Point. Westward this fault zone appears to continue past Temnac Bay, across the headwaters of Kaufman Creek, and to the east shore of Abraham Bay, where it offsets the contact between the Chuniksak Formation and conglomerates of the basement rocks. 


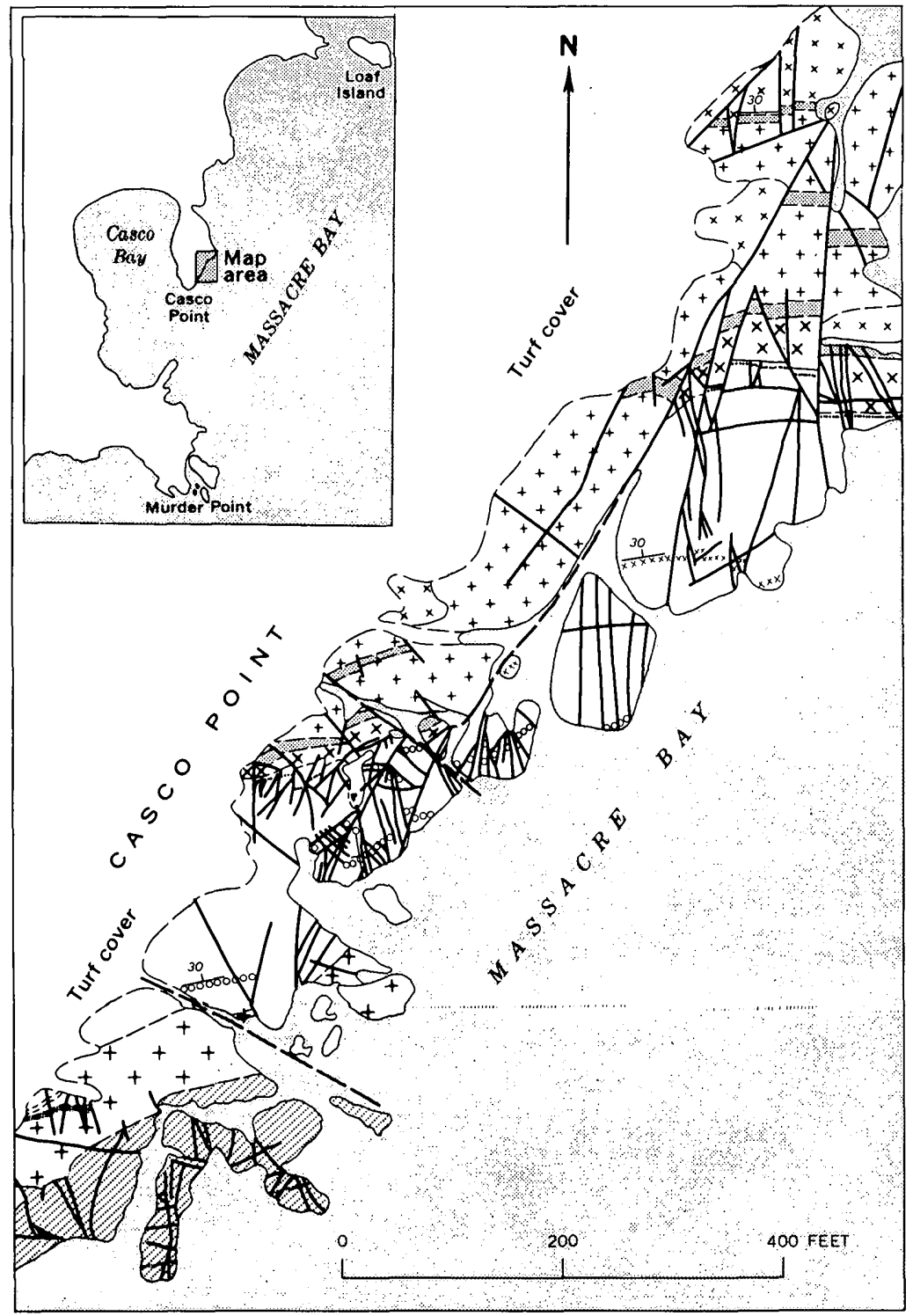

Figure 111.-Geologic map of basement rocks (Mesozoic or 


\section{EXPLANATION}

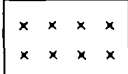

Massive ferromagnesian-rich basalt

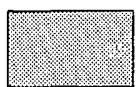

Microconglomerate

$$
\mathrm{H}^{+}+{ }^{+}+
$$

Pillow basalt

$$
\begin{array}{|lll|}
x & x & x \\
x & x & x \\
\hline
\end{array}
$$

Massive feldspar-rich basalt

$$
\begin{aligned}
& \times \times \times \times \times \times \times 1 . .6 \\
& 0000000000
\end{aligned}
$$

Brown-and black-weathering tuff and sandstone

Marker beds indicated by symbols

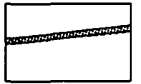

Light-green siltstone

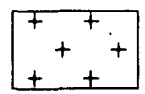

Pillow basalt

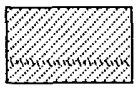

Green tuff and sandstone containing marker bed

$$
\text { Contact }
$$

Dashed where approximately located

Fault or joint

Dashed where approximately located

$$
\text { Strike and dip of beds }
$$

Tertiary) on east shore of Casco Point, Massacre Bay, Attu. 
Another major fault zone parallels this zone a few miles north, extending westward from near Loaf Island, at the head of Massacre Bay, and thence through North Pass at the headwaters of Peaceful River. There it enters the long east-west reach of Temnac Valley and trends slightly north of west, probably as several segments, one through Twin Lakes and thence to the head of Abraham Bay, and another through Abraham-Temnac Pass and thence down Abraham River valley. Although the absolute values of movement have not been established, the observed relations between formations could have originated by a relative upward movement of the northern block. This is also the sense of the very recent movement on this zone where it cuts Pleistocene and Holocene deposits.

The difference in detail and abundance of faults in different parts of the area shown on plate 80 , in part at least, is only apparent, for some parts were studied in more detail and have a stratigraphy more conducive to recognition of fault relationships than others. Important faults and fault zones probably exist, for instance, in the medial part of the island, and, indeed, many suggestive trend lines are present in the aerial photographs. Without adequate stratigraphic control, however, one is reluctant to definitely infer these trend lines to be faults, and only those faults seen during the ground reconnaissance or definitely inferable from the aerial photographs are shown on the map.

Faulting is prominent in the northern part of the island between Holtz Bay and Auburn Cove; and to the west, in the vicinity of Steller Cove, the mosaic of fault blocks is emphasized in the many faulted contacts between the different formations. A major fault zone extends southwestward from Auburn Cove of Steller Cove to Abraham Bay on the south shore, and its importance is further borne out by its topographic continuation offshore as the huge Abraham Sea Valley, one of the largest submarine canyons of the Aleutians. The tectonic significance of this and other submarine features of the area was discussed in some detail by Gates and Gibson (1956).

Still farther west, between Earle Cove and Etienne Bay, many formation contacts are faulted and form a pattern, some of the elements of which have a northeast lineation, and may be interpreted as an extension of the presumed fault zone of Etienne Sea Valley (Gates and Gibson, 1956, fig. 12). West of Kresta Point the structural features are much generalized because of scarcity of field data.

The broad flat bench that extends along the north shore from Earle Cove eastward for a distance of several miles is a recently uplifted shore platform, on which are two perfectly delineated low fault 
scarps which trend slightly south of east and which displace the turf mantle upward on the north (seaward) side. These scarps parallel similar features of the submerged shelf offshore and also the great scarp bounding the Aleutian Ridge only a few miles north (Gates and Gibson, 1956). They demonstrate that some movement on this system of faults has been very recent, no doubt continuing to the present.

Age of the faulting.-The age of the faulting on Attu has not been precisely established, although some of the east-west-trending faults are marked by scarps in the tundra, which indicates that movement has occurred on them in Holocene time. Other faults displace the Massacre Bay and Faneto Formations and therefore are certainly not older than late Tertiary. Those that cut the Nevidiskov and Chuniksak Formations must be middle Tertiary or younger. The faults in the basement rocks, of course, could range in age only from late Mesozoic or early Tertiary (?) to early Pleistocene.

A suggestion that much of the faulting was late Miocene, or at least middle Tertiary, is given by the submarine topography surrounding the Near Islands. Gates and Gibson (1956) showed that many of the lineaments, which they interpreted as faults, have trends parallel to the main trends of the faults on the islands, and some appear to lie along the extension of some of the northeast-trending faults on Attu. The submarine canyons which form these submarine lineaments end abruptly on a slightly warped submarine shelf, as if planed off by erosion. Topographic evidence in turn suggests that this shelf is the platform on which are built many of the volcanic cones farther east along the Aleutian chain, where Pliocene fossils have been found in the rocks associated with the beginning of the cone-building volcanism. It is possible, therefore, that much of the faulting on Attu is pre-Pliocene and perhaps was associated with the uplift which led to formation of the shelf by erosion. A major episode of uplift separated deposition of the Chuniksak Formation from that of the Massacre Bay and Faneto Formations, and many faults are found in the Chuniksak Formation. If faults on the islands were simultaneous with the submarine faults, and if the uplift preceding formation of the submarine shelf was simultaneous with the post-Chuniksak pre-Massacre Bay uplift and erosion, then much of the faulting on Attu is of middle Tertiary or late Miocene age. Some of the faults in the basement rocks may be associated with the uplift preceding formation of the unconformity on the basement rocks, however, and clearly many faults are late Tertiary to Holocene in age. 


\section{AGATTU ISLAND}

\section{STRATIGRAPHY}

The rocks of Agattu are divided into the basement rocks, Krugloi Formation, and two types of intrusive rocks (pl. 81). The basement rocks consist of pillow lava flows, pyroclastic water-laid breccia, water-laid tuff, tuffaceous sandstone and conglomerate, siltstone, mudstone, argillite, and chert. The upper contact is gradational with the Krugloi Formation. The known thickness is at least 4,500 feet. The Krugloi Formation consists primarily of conglomerate, sandstone, mudstone, siltstone, argillite, and chert. Lava flows and pyroclastic deposits are subordinate. The total known thickness is about 7,400 feet.

Diabase and gabbro intrude both the basement rocks and the Krugloi Formation. Mineralogically, texturally, and structurally they resemble the diabase and gabbro of Attu. Dacite porphyry forms long sinuous dikes which radiate from a common center at Krugloi Point, and which cut the basement rocks, the Krugloi Formation, and the diabase intrusives. The dikes are porphyritic and contain extremely large phenocrysts of sodic plagioclase (up to 5 $\mathrm{mm}$ in diameter), quartz, biotite, and hornblende. Similar dacite (without giant phenocrysts) is found on Shemya, but there are no counterparts on Attu.

\section{BASEMENT ROCKS}

The basement rocks underlie about four-fifths of the island and are most completely exposed in the mountain peaks south of Binnacle Bay, along the coast from the east side of Binnacle Bay to Armeria Bay, and along the south coast from Otkriti Bay to Gillon Point. On the central plateau the rocks are obscured by a heavy growth of turf, except for small scattered outcrops on knobs and in gullies. Several lithologic units can be distinguished in the mountains and along the coastlines, but in the broad plateau area exposures are insufficient to permit division into lithologic map units. Color patterns on the geologic map portray areas of distinctive lithologic character, but no contact lines are shown because the location of the contacts is not known.

A composite section from the Binnacle Bay area indicates that there the basement rocks are at least 4,500 feet thick. A section 800 feet thick is present along the south coast, and a tentative correlation between outcrops of the Binnacle Bay area and the south coast gives a total exposed thickness of about 4,800 feet. As the base of the rocks is under water, their total actual thickness is unknown. 
The contact between the Krugloi and the basement rocks is gradational through a zone at least 100 feet thick. The division is made, even though the contact is not precisely mappable in the field, because the Krugloi and the basement rocks differ in bulk characteristics. The basement rocks consist primarily of submarine lava flows, tuffs, and tuffaceous sedimentary rocks; the Krugloi Formation is composed primarily of detrital clastic material, only a few lava flows, and a relatively small amount of pyroclastic material.

\section{SEDIMENTARY ROGKS}

The sedimentary rocks in the basement range from coarse cobble conglomerate to chert. Most of the coarser rocks have tuffaceous matrices, and the fine-grained ones contain significant amounts of minute pyroclastic fragments. Parts of the section are predominantly coarse-grained conglomerate and coarse sandstone, with lesser amounts of fine-grained sedimentary rock. Other parts are composed predominantly of medium- to fine-grained sandstone, siltstone, mudstone, and chert, with lesser amounts of coarse-grained sedimentary rock. The only large thickness that does not contain a mixture of all grain sizes up to pebble or cobble size is the 400 feet of varicolored mudstone, siltstone, chert, and argillite overlying the volcanics west of Binnacle Bay on the north coast (fig. 112) and west of Otkriti Bay on the south coast.

Individual beds of conglomerate range in thickness from 3 to 50 feet. In some places bedding is crude and poorly defined. In other places torrential crossbedding, cut-and-fill structure, and lenses of coarser or finer clastic material are common. Local erosional unconformities between conglomerate and underlying finer grained rocks are also common. Pebble sizes range from less than an inch to about a foot. Some conglomerate beds have fair sorting among the pebbles, most of which are between 1 and 3 inches in diameter; others have a complete range of sizes. The amount of rounding and the number of rounded rock fragments compared with angular ones differ from bed to bed. In many conglomerates most of the lava and tuff fragments are angular and most of the sedimentary rock fragments are rounded. Basalt lava, tuff, sandstone, and dense fine-grained sedimentary rock, all typical of the basement rocks, are the principal constituent rock fragments.

The sandstone beds display many of the same structures as the conglomerate beds, such as crossbedding, cut-and-fill structure, and lensing of coarser and finer beds within a sandstone sequence. Some sandstone layers, however, are thin and persistent, and some sequences are evenly laminated. Contortion and intricate folds of 


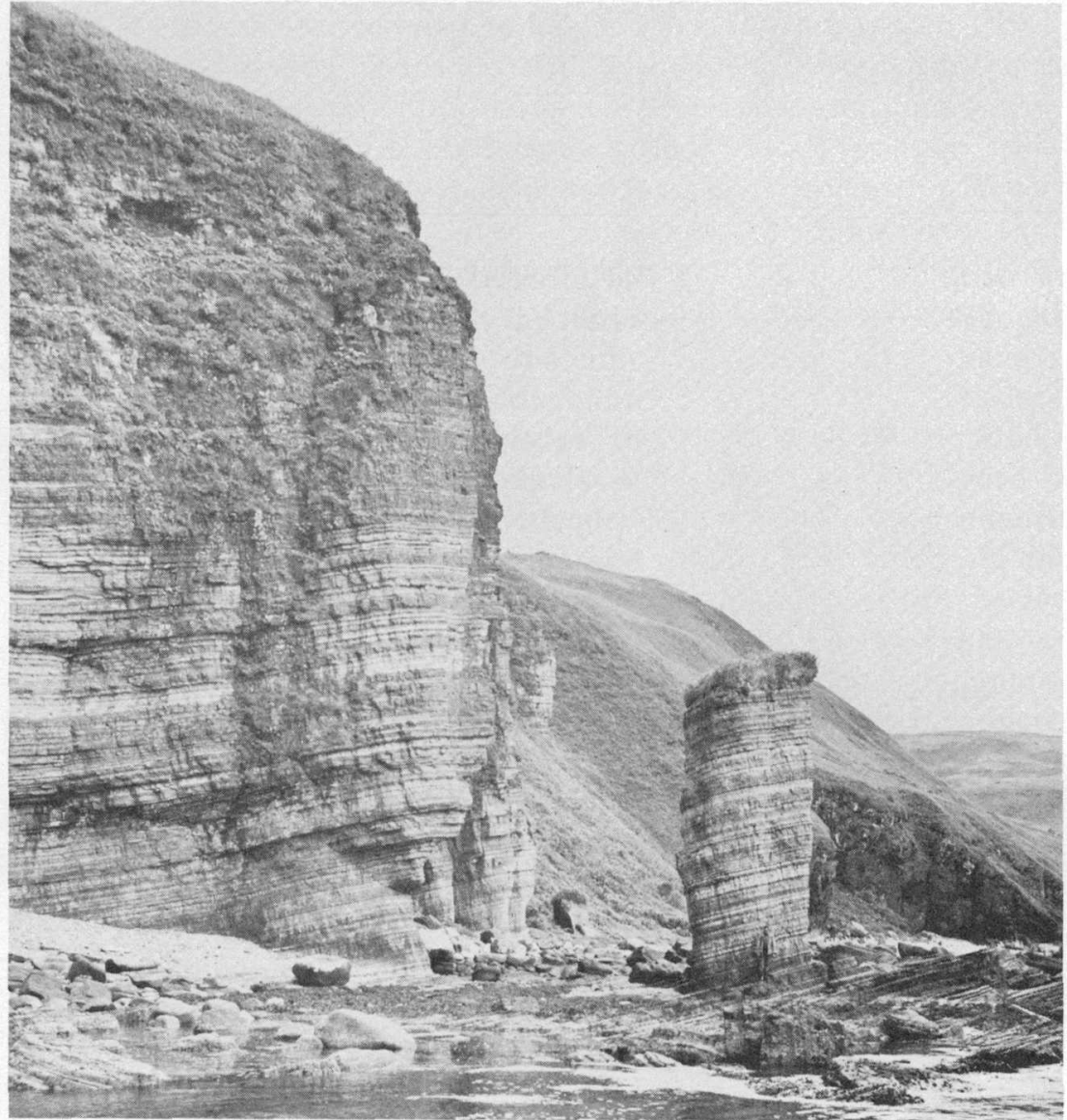

Figure 112.- Varicolored laminated siltstone, chert, and argillite of the basement rocks on the north shore of Agattu, about $2 \frac{1}{2}$ miles west-southwest of Binnacle Bay. Exposure is about 100 feet high.

some laminated sandstone beds were noted in several outcrops. Graded bedding from coarse sand at the base to fine siltstone at the top are also present.

The fine-grained sedimentary rocks include siltstone, mudstone, silica-cemented argillite, and chert. The mudstone beds locally have a tendency toward shaly parting. The most conspicuous characteristic of the fine-grained sedimentary rocks is their excellent bedding. The beds range in thickness from less than an inch to about 2 feet and are separated in most places by a sharp contact, commonly the surface along which the rocks split when weathered or frost-heaved. Within individual beds lamination is conspicuous; some laminations, thin as a pencil line, may persist for many feet. Slight grain-size 
differences are present between layers in some mudstone and siltstone beds. Graded bedding ranging from coarse siltstone at the base to argillite at the top, within a vertical distance of 1 inch, occurs in some layers. Others show a similar gradation in color from dark to light, but no apparent change in grain size.

Intricate folding, faulting, squeezing, and general contortion of the bands and laminations in the fine-grained sedimentary rocks are apparent. In some places the contortion is confined to a single layer, perhaps an inch or two thick, the overlying and underlying layers being little disturbed. In addition, the fine-grained sedimentary rock of the basement rocks display abundant mud chips, faint but intricate crossbedding within layers, and slightly scoured contacts. Approximately vertical tortuous holes, suggesting worm tubes, were seen at some outcrops.

The fine-grained sedimentary rocks are made up primarily of minute fragments of albite, labradorite, pyroxene, and chlorite scattered through a matrix of cryptocrystalline silica, or in some rocks calcite. Detrital quartz is very subordinate in both the coarseand the fine-grained rocks, and biotite and potash feldspar are absent.

\section{PYROCLASTICS}

The tuffs and volcanic breccias of the basement rocks are mainly basaltic. They are olive green to brown and are friable where unaltered. Mild alteration over large areas has changed many to more indurated light-green and gray albitized rocks. Thickness of beds ranges from less than an inch to as much as 50 feet. The finegrained tuff locally shows lamination similar to that of the siliceous argillites and siltstone, with which they are in places interbedded (fig. 113).

Scour and fill occurs commonly at the base of tuff-breccia sequences or between beds. Many of the coarse breccias contain a jumble of unsorted rock fragments, contorted lenses of fine sedimentary rocks, and numerous intrabed faults. The fine-grained beds generally are conformable and show no evidence of scour. Both types of beds commonly show graded bedding, particularly near the top. Larger fragments in tuffs and breccias are mostly angular to subangular and consist of basalt lava, scoria, and minor amounts of argillite and siltstone. The fine-grained constituents of the tuffs and tuff-breccias consist of fragments of devitrified vesicular basaltic glass (now nontronitic), fragments of labradorite and augite crystals, and interstitial zeolites. No granitic, gneissic, or schistose rock fragments were found. 


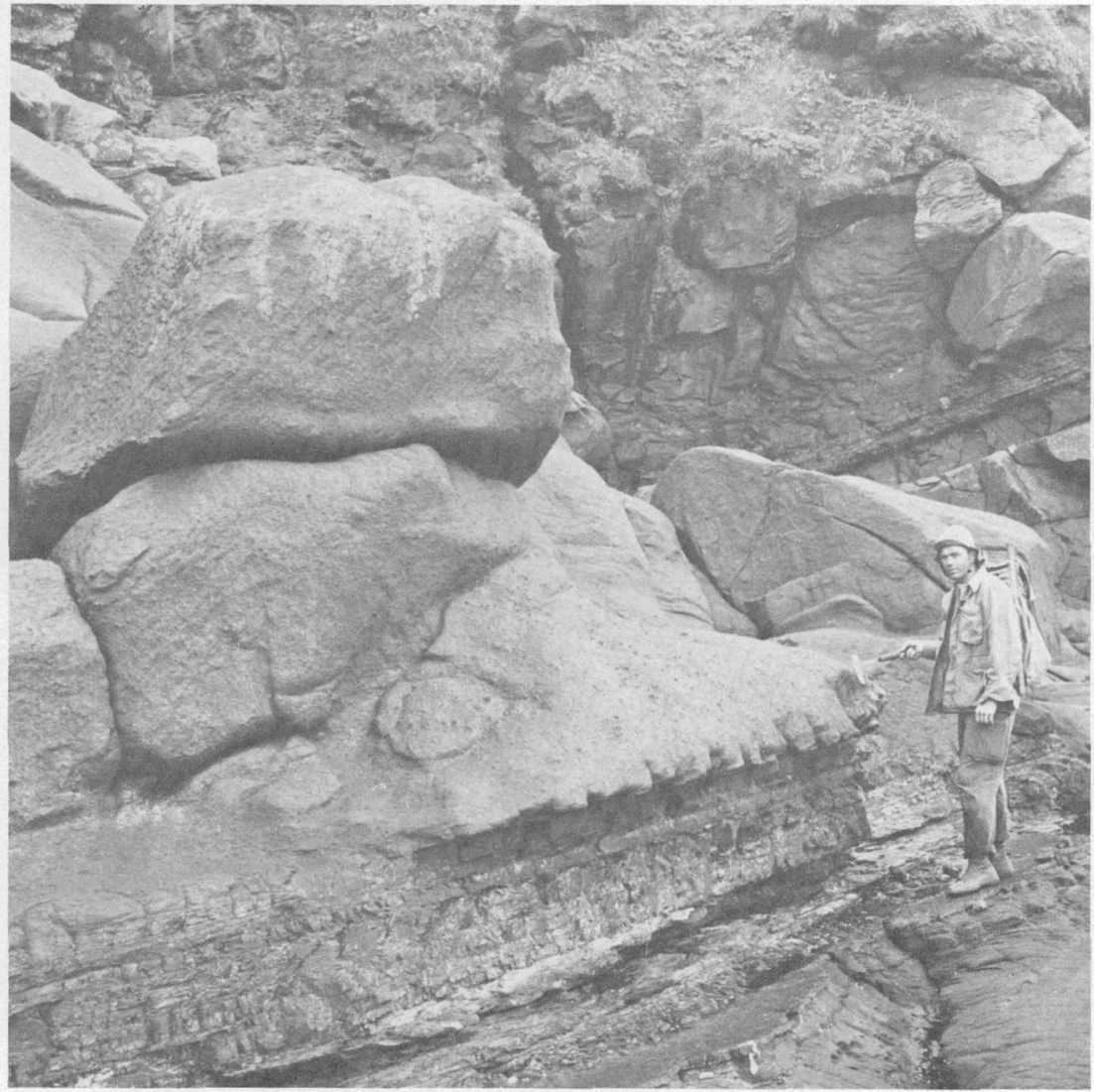

Figure 113.-Thin-bedded siltstone between basaltic tuff-breccia of the basement rocks on the north shore of Agattu, about 3 miles west-southwest of Binnacle Bay.

On the north coast, tuff and tuff-breccia occur in massive beds 2-25 feet thick separated by 1- to 4-foot-thick beds of fine-grained laminated siliceous mudstone and siltstone (fig. 113), and are overlain by 400 feet of varicolored fine-grained laminated sedimentary rocks (fig. 112). Bedding in the tuff is not anywhere sharply defined, but a gradational change from coarse breccia at the base of any one bed to dense fine-grained tuff at the top is typical. The upper finegrained tuff in turn grades into fine-grained well-bedded siltstone and argillite. Above this there is a sharp change to coarse material again, the beginning of the next graded bed of tuff-breccia. These graded sequences of volcanic material are either direct deposits from submarine volcanic eruptions or are submarine mudflow and turbidity-current deposits closely related to eruptions. 
Along the south coast, the tuff and tuff-breccia beds show a greater diversity than on the north coast. Some tuff-breccia beds on the south coast have local unconformities, contorted bedding, and admixture of detrital materials. At one locality a tuff-breccia containing slabs of tuffaceous sandstone and well-bedded siltstone is overlain on a hummocky irregular surface by columnar tuff.

Specimen 50W13 (table 1) is a typical fine-grained tuff collected from the north shore of Agattu, $21 / 2$ miles west-southwest of the head of Binnacle Bay (fig. 113). The lower part of the 20 -foot-thick bed is coarse tuff-breccia that grades upward into simple uniformly dark-oily-green tuff. Under the microscope the tuff is seen to be composed of particles of devitrified glass and crystals up to about $0.3 \mathrm{~mm}$ diameter. The crystal fragments are plagioclase relicts (now converted to analcite and other zeolites), fresh augite, and a little opaque oxide. The cellular "glass" particles are now pleochroic deep-brown-green (probably nontronitic) material. The interstices are filled with analcite and minor amounts of other zeolites, which compose about a third of the rock.

The persistence of fresh augitic pyroxene in these basaltic tuffs is in sharp contrast to the common replacement of the calcic plagioclase by analcite and the conversion of the basaltic glass to nontronitic material. The large amount of analcite as pseudomorphs and as interstitial fillings accounts for the relatively high soda contents shown by the chemical analyses (analyses 2 and 3, table 1). A widespread variant of these basaltic tuffs is represented by an albiteamphibole rock, especially common on western Agattu. It is described in connection with the diabasic intrusions and their effects on the country rocks.

\section{LAVAS}

Most lava flows in the basement rocks are basaltic and about 20 feet thick, but some are as much as 150 feet thick. Many, especially on the south coast, show well-developed columnar jointing; others show well-developed pillows with interstices filled with chert or other material such as tuff or argillite. A few have distorted and intricately folded laminated argillite both above and below, as if the lava had intruded soft muds. Pinchout of lava flows between siltstone layers, which no doubt is of common occurrence, is clearly shown at the southwest corner of Karab Cove.

Characteristic of the lavas of the basement rocks is their intimate association with sedimentary and stratified pyroclastic rocks. Most flows are thin and separated from each other by lenses or persistent beds of fine-grained sedimentary rocks or tuff. A typical sequence, found on the southeast flank of Peak D, is as follows: 


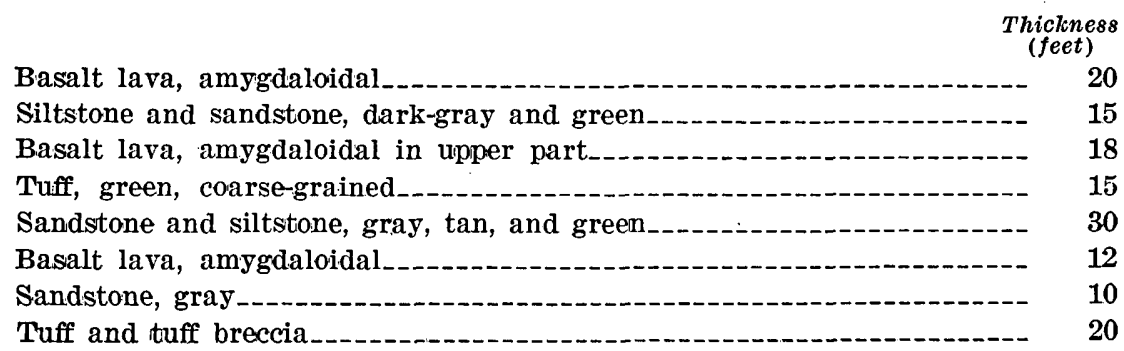

Petrographically the basaltic lavas of the basement rocks on Agattu resemble closely those of the basement rocks on Attu. (See descriptions on specimens 50P85, 50P86, and 50P293, (p. 720.) Here again a large part of the plagioclase of the basaltic lavas is cloudy albite and the pyroxene is fresh-appearing augite, and the conclusion is drawn that the spilitic character of the rocks is secondary rather than due to an especially sodic magma (Wilcox, 1959).

Although most of the lavas are basalt, one, at the south edge of the plateau 1 mile east of Gillon Point, is keratophyric.

Specimen 50W2 (table 1 ) is composed of many dusty albite phencrysts and a few clusters of pleochroic yellow-brown material (pseudomorphs?) and opaque oxide set in a groundmass of abundant microphenocrysts of albite, some of orthoclase, quartz, amphibole, opaque oxide, and a granophyric mesostasis. Sphene (altering to leucoxene) and apatite are minor constituents. The phenocryst-size masses of pleochroic yellow-brown material, having high birefringence, high relief, and extinction parallel to crude fibrous structure, is perhaps a bowlingite type of alteration from orthopyroxene. The amphibole microphenocrysts have an extinction angle $\mathrm{Z}: c=15^{\circ}$ and a pleochroism from pale yellow to pale green blue and may be riebeckite.

The following is a generalized columnar section describing the basement rocks in the Binnacle Bay area on the north shore. There are undoubtedly many small faults in the section not found during the reconnaissance mapping, but probably none involve more than 200 feet of stratigraphic separation.

\section{Section of basement rocks near Binnacle Bay, north shore of Agattu}

Top of section eroded. No overlying rocks present. Approximate thicknes
(feet)

Tuffaceous' sandstone interbedded with siliceous mudstone and siltstone

Tuff, water-laid, in beds up to $10 \mathrm{ft}$ thick interbedded with thin beds and lenses of siltstone and mudstone, some of which are finely laminated...-

Layered mudstone and siltstone, brown and yellow, grading upward into coarse brown and green sandstone and tuffaceous sandstone with a few thin beds of siliceous banded argillite

Tuff in beds 6 in. to $2 \mathrm{ft}$ thick interbedded with argillite in beds $1-3$ ft thick.

Argillite and siltstone, finely laminated 
Section of basement rocks near Binnacle Bay, north shore of Agattu-Continued

Approximate thickness

Mudstone, siltstone, and sandstone, well-bedded, thinly bedded; interbedded with thin persistent ash layers.

Lava flows, basaltic, 1- to 2 -ft-thick, separated by lenses of well-laminated, siliceous argillite and sandstone ; lava is amygdaloidal and porphyritic.-

Siltstone and sandstone, siliceous, with tuffaceous matrix

Lava flow

Argillite, siltstone, and sandstone; siliceous; laminated._._._._._._.-.- 110

Lava flow

Siltstone and tuffaceous sandstone, interbedded.

Conglomerate and sandstone with tuffaceous matrix; rounded pebbles as much as 2 in. in diameter.

Siltstone, gray, green, and tan, medium- to thin-bedded, and medium- to thick-bedded tuffaceous sandstone

Chert, green and cream colored, well-bedded and laminated, interlayered with well-bedded sandstone.

Sandstone, caarse, and interbedded water-laid tuff

Most of this part of section covered by turf. Those rocks cropping out are tuffaceous breccia, tuffaceous conglomerate, coarse tuffaceous sandstone, and tuff, all of which tend to form thick massive beds. Interlayered with these are beds of chert, argillite, mudstone, siltstone, and fine sandstone, all of which tend to be well and thinly bedded. Ratio of coarse-grained rocks to fine grained is about 3 to 1

Chert argillite, siltstone, and mudstone, well bedded in beds 1-6 in. thick. Many beds finely laminated; some laminations contorted and folded, - suggesting contemporaneous deformation. Entire section strikingly colored in pale reds, greens, blues, and yellows

Tuff-agglomerate, basaltic, in massive beds 5-25 ft thick. Graded bedding from coarse bombs at base to fine-grained laminated tuff at top. Beds are separated by 1 - to 2 -ft layers of siliceous mudstone and siltstone

Total

Base of section at sea level.

Reconstructed section (greatly faulted) on south shore, Agattu

Top of section eroded.

Approximate thicliness

Chert, argillite, siltstone, a few limy beds; pale red, green, yellow, and

blue; well bedded and laminated.... 400

Pillow lava flow, basaltic

Siltstone, fine-bedded and well-bedded._-_-_-_-_- 30

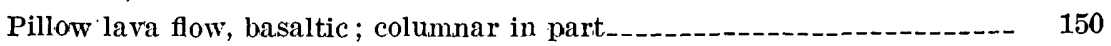

Tuff-breccia, bluish-green and dark-gray to black, basaltic, massive, with interbedded siltstone; bottom $20 \mathrm{ft}$ has many lava fragments with con-

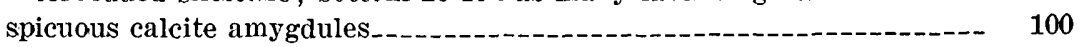

Basaltic pillow lava flow with silica amygdules__-_-_-_-_-_-_._-_._- 40

Total _-.

Bottom of section is sea level. 


\section{KRUGLOI FORMATION}

The Krugloi Formation is here named for its good exposures in the mountain peaks from Krugloi Point westward to Peak I. The formation covers the eastern one-fifth of the island from the north shore to the south shore. Total exposed thickness is about 7,400 feet; the bottom contact is gradational into the basement rocks, and the top contact is covered by the sea.

The Krugloi Formation resembles the basement rocks in general lithology but differs from them sufficiently to be mapped as a separate formation. Although both units contain volcanic material, the direct contribution of volcanism to the Krugloi rocks is represented by only one sequence of tuff and lava. There are relatively few angular tuff and lava fragments in the conglomerate beds, and tuffaceous material is very subordinate in the matrix of the coarse clastic beds, which consists primarily of silica- and carbonatecemented clay, silt, and fine sand. The submarine pyroclastic beds and the slumping and contemporaneous deformation characteristic of the finer grained sedimentary rocks of the basement rocks are lacking in the Krugloi Formation. The proportion of coarse clastic sedimentary rocks to fine-grained sedimentary rocks is greater in the Krugloi Formation than in the basement rocks. Coarse sandstone and pebble conglomerate constitutes at least two-thirds of the detrital sedimentary rocks, and appreciable thicknesses of fine-grained rocks, such as the 400-foot-thick sequence in the basement rocks, are absent. Many of the fine-grained sandstone beds have a distinctive onionskin type of exfoliation.

On the other hand, the Krugloi and the basement rocks have many characteristics in common. The composition of the rounded cobbles and pebbles of both formations is similar, suggesting the same source terrane. Sandstone, fine-grained siliceous sedimentary rocks, basaltic lava, and tuff are the principal rock types. No granitic or schistose rocks were found among the cobbles and pebbles. Like the basement sedimentary rocks, the Krugloi conglomerate and sandstone beds have much crude torrential crossbedding, cut-and-fill structures, local unconformities, and lensing of beds. Interlayering of coarse clastics and fine-grained sedimentary rocks occurs throughout most of the Krugloi Formation. In general the coarse-grained rocks occur in massive or very crudely bedded layers as much as 15 feet thick. The fine-grained rocks generally form well-bedded and laminated layers rarely more than 3 feet thick.

The single sequence of volcanic rocks in the Krugloi Formation lies about 2,400 feet above the base of the formation. On Cone Peak and Peak M-N, a porphyritic basaltic lava flow about 50 feet thick 
is underlain by about 200 feet of massive green tuff and tuffaceous sandstone. On Monolith Point, north of McDonald Cove on the east coast, two flows are present. The lower one is a basaltic and porphyritic pillow lava that resembles the lava on Cone and $\mathrm{M}-\mathrm{N}$ Peaks. Above this flow is about 70 feet of coarse tuff and thin-bedded, well-bedded, fine-grained rocks. Overlying these rocks is a basaltic pillow flow with large amygdules. The differences in stratigraphy between the two areas not more than a mile apart indicate rapid facies changes and local distribution of a particular unit.

The following very generalized section is based on mapping traverses, not on measured sections. Undoubtedly there are many inaccuracies resulting from undetected faults as well as extrapolations of dips.

\section{Generalized section of Krugloi Formation, northern Agattu Island}

Siltstone, mudstone, and argillite, well-bedded, and bluish-gray finegrained sandstone; bedding generally thin and very distinct

Interbedded argillite, mudstone, siltstone, sandstone, and pebble con-

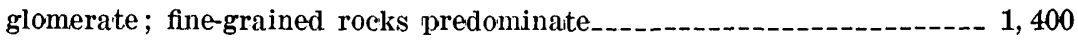

Sandstone and pebble conglomerate, green, coarse; in beds as much as $10 \mathrm{ft}$ thick interbedded with thin layers of siltstone, mudstone, and argillite; much crossbedding in the coarse clastic rocks

Boulder conglomerate with boulders as much as $3 \mathrm{ft}$ in diameter; coarse thick-bedded sandstone and pebble conglomerate; thin beds of finegrained sedimentary rocks; much lensing of the fine-grained layers

Sandstone, coarse, and pebble conglomerate in thick beds; thinner beds of fine-grained sedimentary rocks

Lava flow, porphyritic; pillows present in some places, columnar structure in oithens.

Tuff, green, coarse, and tuffaceous sandstone in massive beds--.-.-..-----

Sandstone, siltstone, and argillite, brown, well-bedded; no very coarse clastic sedimentary rocks.

Sandstone, silitstone, and argillite, bluish-gray; entire sequence well bedded; sandstone predominates

Total -

Gradational contact with the tuff-breccia and tuffaceous sandstone and conglomerate of the basement rocks.

The basement rocks of Agattu were apparently deposited in the same general volcanic and tectonically active marine environment as the basement rocks of Attu. The Krugloi Formation represents a gradual change to less heterogeneous conditions, primarily through the reduction of volcanic activity, an increase in clastic material, and a decrease in tectonism and local relief. 
Age of the basement rocks and the Krugloi Formation.-No fossils were found in either of these units. They are correlated with the Mesozoic or Tertiary basement rocks on Attu solely on the basis of similar lithologies in both sedimentary and volcanic rocks.

\section{SURFICIAL DEPOSITS}

The turf mantle on disintegrated rock is widespread at low altitudes on Agattu. The thin-bedded sedimentary rocks of the basement rocks and the Krugloi Formation are singularly vulnerable to frost action, and, since glaciation, an appreciable thickness of "soil" has been produced in which the grasses and other plants have taken root. On steep slopes this mantle of turf tends to creep, as has also been noted on Attu, and produces lobes and banks or terraces. Glacial deposits are rare on Agattu. A conspicuous boulder train extends south-southwest several miles from the diabase outcrop on the southeast flank of Peak E. Unlike on Attu, alluvial fill and fans are not common; they are found only near Otkriti Bay, Aga Cove, McDonald Cove, and at a few other places. Beach deposits are small and sparse and are included with alluvium on the geologic map. A more detailed description and discussion of these features is given in the section on surficial geology by J. P. Schafer.

\section{INTRUSIVE ROCKS}

\section{DIABASE}

The diabasic rocks, which include diabase, quartz diabase, gabbro, and quartz gabbro, are mineralogically and texturally similar to those of Attu (p. 744). They occur in all parts of the island but are particularly abundant west of a line between Patricia Bight and Karab Cove. Most of the diabasic intrusives form large lenses or sill-like bodies, in some places parallel to the bedding of the enclosed sediments but more commonly cutting across the bedding at low angles ranging up to $10^{\circ}$.

The tabular lens under the peaks south of Binnacle Bay, which can be traced on the map (pl. 81), appears to be typical. From its southern end, where it pinches out between sedimentary basement rocks, it gradually thickens northward to a maximum of about 500 feet under Peak E, thence it gradually thins to about 100 feet under Peak U, beyond which it is cut off by erosion. The general dip of the lens conforms approximately to the regional dip of the enclosing sedimentary rocks. Exposures of the contacts are poor except on the north nose of Peak F, where both top and bottom contacts are clearly parallel to the bedding of the basement rocks. 
Excellent exposures of the bottom contact of another diabase body in sedimentary rocks were found at triangulation station KI'TE on the south coast, $21 / 2$ miles west of Cape Sabak. High in the cliff, the bottom contact makes an angle of about $2^{\circ}$ with the southwarddipping bedding, and downdip at sea level the same contact makes an angle of about $10^{\circ}$ with the bedding. A similar steepening of the dip of a gabbro lens so that it cuts across bedding at an angle that increases downdip is well exposed at the northwest corner of Otkriti Bay on the south coast.

Some of the lensing tabular intrusive bodies have knobby, irregular upper surfaces, remnants of which can be seen where erosion has stripped away the overlying sedimentary rocks. In the knobby area from Patricia Point southward, gabbro is exposed on the knobs and plunges under remnants of sedimentary rocks exposed in the depressions. These features are also exhibited on the intrusive near Krugloi Point and on the one at the western end of the island.

Small irregular intrusive masses of diabasic rocks cut across the regional dip of the sedimentary rocks at steep angles, and there are many sinuous dikes ranging in width from thin stringers only a few feet wide to vertical tabular bodies as much as 1 mile long and 100 feet wide.

Specimen 50P269 (table 1), from a 30 -foot-wide dike in the shore platform three-fourths mile north of the head of Binnacle Bay on the north shore of Agattu, is a quartz diabase with subophitic texture and grain size up to about 1. $\mathrm{mm}$ diameter. It is composed of about 60 percent plagioclase, 12 percent augite, 12 percent antigorite, 6 percent quartz, 4 percent opaque oxide, 4 percent chlorite, and 2 percent carbonate, apatite, and other accessories. The plagioclase is zoned normally from labradorite in the broad central areas to andesine and oligoclase at the rims. Central parts carry sericite, chlorite, and dusty particles; the outer parts are generally clear. The augite has $(+) 2 \mathrm{~V}=48^{\circ}-49^{\circ}$ and $n \mathrm{Y}=1.691-1.693$, implying a composition near $\mathrm{Ca}_{40} \mathrm{Mg}_{42} \mathrm{Fe}_{18}$. Pigeonite was looked for but not found. The green pleochroic antigorite is in part an alteration product of pyroxene, perhaps both from the augite and from orthopyroxene (or pigeonite) now completely converted. The opaque oxide commonly occurs as skeletal crystals up to one-half millimeter in diameter. Quartz in moderately large grains is interstitial. Long needles of apatite are common in the quartz.

The larger diabase and gabbro masses are heterogeneous texturally and mineralogically. A common variation within the coarser parts of the large intrusive at the western end of Agattu is a concentration of pyroxene and opaque oxide in clots spaced about 1 centimeter apart. Locally these clots form rudely parallel lenticules spaced as much as $3 \mathrm{~cm}$ apart. In other places the ferromagnesian minerals are concentrated in parallel bands $3-10 \mathrm{~cm}$ apart and at right angles to the columnar jointing. Streaks, pods, and irregular dikes of pegma- 
tite are common, and many of the gabbro bodies are cut by dikes of diabase or basalt with conspicuous chilled selvages.

Alteration of country rock near contacts with diabase is common but differs widely in intensity. Along the contact on the north nose of Peak F, the adjacent siltstone and argillite show only slight bleaching and silicification. Basaltic tuffs seem to have been particularly vulnerable to alteration, and the zones of alteration extend many feet from the diabase contact. On the north coast of Agattu, about 21/4 miles west of the head of Binnacle Bay, a 30-foot-wide diabase dike cuts the tuff-breccia described previously in the discussion of unaltered pyroclastics (fig. 113, and specimen 50W13).

Specimen 50P244 (table 1) is from the margin of the diabase dike. Under the microscope it is seen to have ophitic texture and to contain about 60 percent plagioclase, 20 percent augite, 5 percent magnetite, and about 5 percent each of chlorite, biotite, and quartz interstitial to the other constituents. The central parts of the plagioclase are albite crowded with sericite and dusty inclusions; the rims are clear oligoclase-albite. The augite is fresh and clear with $(+) 2 \mathrm{~V}=45^{\circ}-47^{\circ}$ and $n \mathrm{Y}=1.697$, implying a composition $\mathrm{Ca}_{38} \mathrm{Mg}_{38} \mathrm{Fe}_{24}$. There are no signs of alteration of the pyroxene to amphibole, biotite, or chlorite as seen in some other diabases of the region.

Specimen 50P245 (table 1) is tuffaceous breccia collected about 75 feet from the dike of specimen 50P244 and beyond the zone of alteration next to the dike. It is coarser than the tuff of the same series described above (specimen 50W13) and contains a few basaltic fragments up to several inches in diameter. The rock is composed chiefly of fragments less than $3 \mathrm{~mm}$ in diameter. In thin section a few particles of holocrystalline basalt are seen; most of the specimen, however, consists of a mixture of particles of vesicular olive-green devitrified glass up to $2 \mathrm{~mm}$ diameter, fresh clinopyroxene up to $0.5 \mathrm{~mm}$ diameter and with $(+) 2 \mathrm{~V}=48^{\circ}$, and analcite pseudomorphs after plagioclase up to $0.5 \mathrm{~mm}$ diameter. As in specimen $50 \mathrm{~W} 13$, the devitrification product of the glass appears to be nontronitic, and the vesicles and interstices are filled with analcite and another zeolite, probably natrolite.

Specimen 50P250 (table 1) is tuff-breccia collected 6 inches from the contact with the dike of specimen 50P244, which similarly affects the tuff for distances of 20 feet outward. In hand specimen the rock is a dull gray rather than the dark oily green brown of the normal rock, and the holocrystalline basaltic fragments tend to stand out more because of their darker color. Under the microscope the same cellular and tuffaceous texture as that of 50P245 is seen, but here the sworls of the tuffs shards are emphasized by streaky segregations of tiny opaque oxide particles. The shards have been transformed chiefly to a mat composed of pale pleochroic green amphibole, $\mathrm{Z}: c$ about $20^{\circ}$, as rods mostly less than $0.03 \mathrm{~mm}$ long, and minor amounts of albite and a pleochroic yellowgreen material with parallel extinction (antigorite?). The original large crystals of clinopyroxene have altered to amphibole with optic angle $(-) 2 \mathrm{~V}=77^{\circ}$, extinction angle $\mathrm{Z}: c$ about $20^{\circ}$, and pleochroism as follows: $\mathrm{X}=$ olive green, $\mathrm{Y}=$ pale yellow, and $\mathrm{Z}=$ pale olive green. The original plagioclase crystals are now pure albite of slightly dusty aspect.

The petrographic characteristics of these rocks suggest that intrusion of the diabase dike altered the original clinopyroxene of the 
tuffs to amphibole, the analcite and any labradorite relicts to albite, and the nontronite to a mixture of amphibole, opaque oxide (magnetite?), antigorite (?), and albite. Possibly the mild alteration of the original basaltic glass to nontronite and of the original plagioclase to analcite, together with analcite impregnation, was a more distant effect of the intrusion.

Age.-The diabasic rocks of Agattu are younger than the basement rocks and the Krugloi Formation and older than the dacite porphyry. Because they represent the same magma type and mode of intrusion as the diabasic rocks on Attu, they are considered to be primarily of middle Tertiary age.

\section{DACITE PORPHYRY}

Dacite porphyry cuts both the basement rocks and the Krugloi Formation and several of the diabase and gabbro bodies in the eastern third of the island. It contains striking phenocrysts of quartz, plagioclase, biotite, and hornblende, some as much as an inch long, in a light-gray fine-grained matrix. From outcrop to outcrop the rock varies considerably in its relative proportion of phenocrysts, especially quartz. On the map ( $\mathrm{pl} .81$ ) the dikes of dacite porphyry show a crude pattern radial to a complex of similar dikes on Krugloi Point (shown on the map as a single mass). The dikes are long and sinuous, and some are traceable to points north of Cape Sabak, 8 miles from the Krugloi Point center. This system of dikes most probably represents the feeder system of a former dacitic volcano centering near Krugloi Point.

Specimen 50D4 (table 1) is a dacite porphyry dike from McDonald Cove, eastern Agattu. Phenocrysts are stubby oligoclase up to $5 \mathrm{~mm}$ in diameter, rounded quartz up to $3 \mathrm{~mm}$ in diameter, prisms of amphibole up to $2 \mathrm{~mm}$ long, rounded and split sheaves of dark mica up to $1 \mathrm{~mm}$ long, and scattered prisms of apatite and rare sphene up to $0.2 \mathrm{~mm}$ in size. These are set in a groundmass containing abundant microphenocrysts of oligoclase and amphibole, some of quartz, and scattered tiny opaque oxide crystals in a fine granophyric matrix which, judying from the marked negative relief, may carry tridymite as well as orthoclase. The outer parts, of the oligoclase phenocrysts are cut by a meshwork of albite veinlets which also contain a little tridymite. Most of the microphenocrysts are intricately veined by albite. The amphibole prisms are euhedral and fresh, showing $\mathrm{Z}: c$ about $16^{\circ}$ and pleochroism as follows: $\mathrm{X}=$ pale yellow green, $\mathrm{Y}=$ dusky green, $\mathrm{Z}=$ deep green. The dark mica shows yellow to brown pleochroism, and the flakes are somewhat deformed; in many the cleavage is open, and a very low index material resembling tridymite is present between the cleavage plates. Globules of sphene are scattered along the cleavages.

\section{STRUCTURE}

The structure of Agattu is portrayed on the geologic map and cross sections (pl. 81) and on the structure map (pl. 82). The cross 
sections give a qualitative picture of the structure. The structure map is based on aerial photographs supplemented by the geologic map.

The regional structure of Agattu is relatively simple. The regional dips, averaging $5^{\circ}$ to about $20^{\circ}$, are eastward on the eastern part of the island, gradually swing to the southeast and south in the central part of the island west of Karab Cove, swing to the southwest in the area between Armeria Bay on the north coast and triangulation station ABLE on the south coast, and finally swing to the south again in the westernmost part of the island. Essentially the regional structure is a broad anticline plunging to the southeast between Krugloi Point and triangulation station ABLE coupled with part of a syncline plunging to the south or southwest from triangulation station ABLE west to Gillon Point.

The bedding trace lines on the structure map (pl. 82) show that there are numerous open minor folds within this broad regional fold. It should be noted that many details of form of the bedding trace lines are simply effects of topography on the outcrop pattern of uniformly dipping beds. In a few places, small-scale drag folds along faults were noted in the field, but such folds are not as prevalent as might be expected in such a highly faulted area. The notable steepening of the dip along the east coast between Krugloi Point and Cape Sabak suggests that a major structural feature may lie offshore.

This open regional fold is broken into many blocks by a network of many fractures, some of which have appreciable displacements and others very little. The fractures, most of which strike between north and east-northeast (fig. 114), make very marked topographic troughs along which many of the other fractures terminate or are offset. A subordinate set of fractures strikes between northwest and north-northwest.

The amount and direction of actual displacement on the faults were not generally determinable in the field. Vertical stratigraphic separation ranges from a few feet to at least 3,000 feet, and comparatively large apparent displacements were noted on a few faults. The fault trending south-southwest from Binnacle Bay has about 500 feet of vertical stratigraphic separation; the faults extending east-northeast from triangulation station WILD, at least 1,000 feet; the one between Aga and Karab Coves, at least 3,000 feet; and the one from McDonald Cove northeast to the north coast about 2 miles west of Krugloi Point, about 1,000 feet. The net effect of this major faulting was to raise the rocks in the southeastern part of the island east of Karab Cove about 5,000 feet relative to the position they 


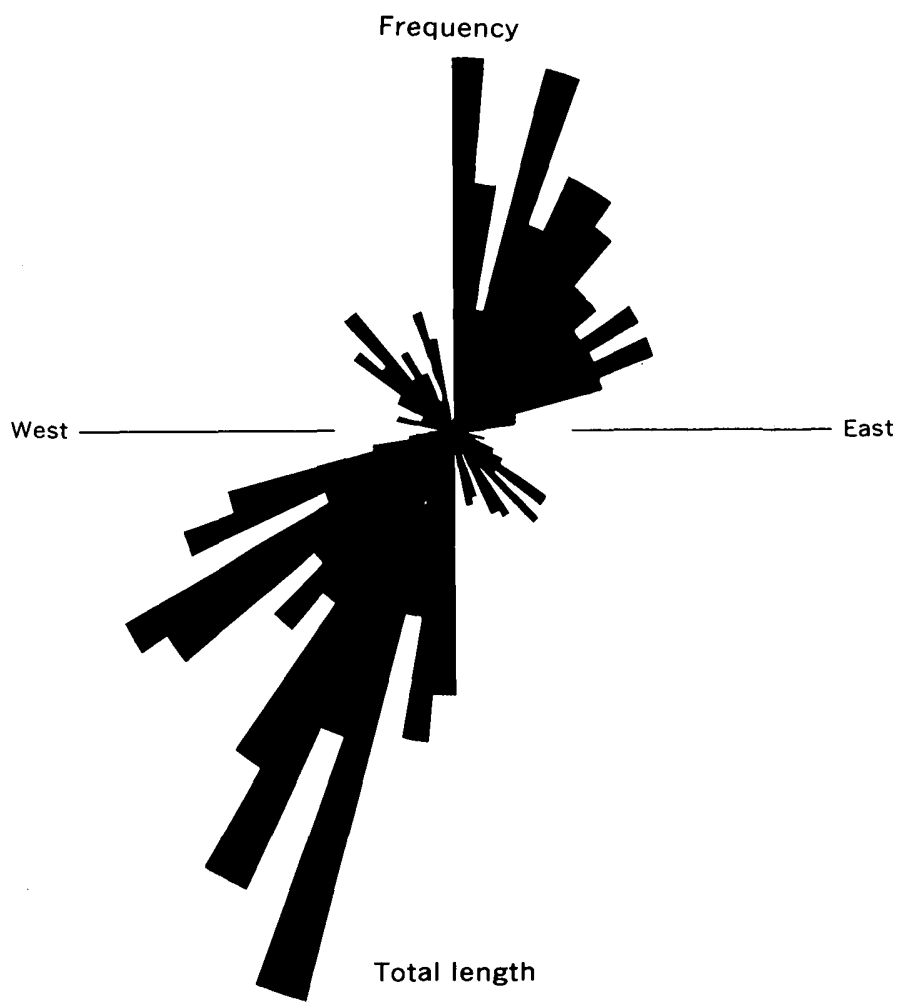

Figure 114.-Rose diagram of fracture trends on Agattu. Part above east-west line represents frequency of fractures within each $5^{\circ}$ sector; part below represents total length of fractures.

would have had without faulting, as determined by extrapolating the regional dip to the southeast. Most of the displacement apparently occurs along the Karab Cove-Aga Cove fault. The long throughgoing fault west-southwest from McDonald Cove displaces the gabbro lens under Peak E only about 100 feet vertically.

Typical of Agattu faults is the network along the south coast from Otkriti Bay west to triangulation station ABLE. The cliffs along the coast display evidence of much block faulting, with vertical stratigraphic displacements ranging from 50 to 500 feet, that created a succession of small horsts and grabens in which the net vertical displacement is only about 300 feet, up on the east.

In addition to mapped single faults, the sea-level rock benches along the shorelines of Agattu show innumerable zones of shearing, breccia, and gouge which crisscross each other without any regular pattern of displacement and which cannot be traced away from the bench or connected with fracture zones seen on the aerial photo- 
graphs. Many such zones were also noted in the northern mountainous area.

The pattern of the faults on Agattu, as shown on the structure map (pl. 82), and the horizontal or gently inclined slickensides commonly seen on fault surfaces throughout the island suggest that many faults are strike-slip faults with associated gash or shear fractures. The only places where the amount of the horizontal component of movement has been estimated, however, are along those faults which offset vertical dikes. For example, the four faults northwest of Cape Sabak apparently have a combined horizontal shear movement of as much as 1,000 feet, the Cape Sabak side moving northeastward.

The fault planes have a wide variety of characteristics, none of which seem to fit any orderly pattern or sequence. Some faults are represented by clean sharp breaks; others by gouge and breccia zones as much as 20 feet wide. Some zones are free of mineralization; others are choked by siliceous vein material, carbonate, or zeolite.

Age of the faulting.-The relations of the faults to the diabase and dacite intrusive rocks suggest at least three episodes of faulting: prediabase, postdiabase-predacite, and postdacite. Two fault zones suggest prediabase age: a fault gouge and breccia zone 15 feet wide on Peak G, which is cut by a gabbro lens, and a fault that extends northward from a point on the south coast about a mile east of triangulation station IBEX. This fault where seen along the coastline consists of a narrow gouge and breccia zone with many small faults. Its extension, which is clearly evident on the aerial photographs, is cut by two gabbro dikes without offset of the dikes at the fault trace. On the structure map several other fractures appear to stop at the borders of a gabbro intrusive.

Only one fault gives conclusive evidence of postdiabase-predacite age. This is the fault extending northeast from McDonald Cove and previously noted as having about 1,000 feet of vertical stratigraphic separation. This fault offsets the Krugloi Point gabbro body but not the two dacite dikes that cut the fault. Postdacite faulting is evident in the Krugloi Point area where several faults offset dacite dikes. A dacite dike is also offset by a fault striking west-southwest from a point on the east coast about 2 miles north of Cape Sabak. The great majority of the faults cut diabasic intrusions and thus are younger than the diabase; but as they lack intersections with dacite dikes, it is not known whether they are also younger than the dacite. It is assumed that many of the faults on Agattu, except perhaps the ones clearly prediabase or postdacite, are of middle Tertiary age and represent the same middle Tertiary deformation postulated for Attu. 


\section{SHEMYA ISLAND}

\section{STRATIGRAPHY}

The basement rocks (fig. 115) are a series of argillitic, tuffaceous, and conglomeratic rocks in the western half of the island. These rocks may be middle Tertiary in age and roughly equivalent to the Chuniksak Formation of Attu. Probably younger is a layered sequence of bedded pyroclastic rocks found chiefly in the northeastern part of the island. These pyroclastic rocks dip gently northwestward and are cut by basalt pipes which may be feeders for some of the pyroclastics. Youngest of the bedrock units are the feldspar and hornblende porphyry intrusives that crop out along the northeast and southeast shores and locally inland.

The whole bedrock sequence of Shemya was planed off, presumably by marine erosion, in late Tertiary or early Quaternary time, then uplifted and tilted slightly to the south. Only relatively thin layers of subsequently deposited unconsolidated materials lie on this platform. These surficial deposits, together with their implications as to recent history of the island, are discussed more fully by J. P. Schafer in the section "Surficial Geology of the Near Islands."

\section{BASEMENT ROCKS}

The basement rocks, which are extensively exposed around the shores of the western half of the island, consist mainly of fine-banded argillites, limy argillites, siltstone, graywackes, and conglomerates that dip north to northwest. Silicified and pyritized lava overlain by bedded cherty sediments and graywackes that dip about $50^{\circ} \mathrm{N}$. occurs at the head of Alcan Harbor. A quarter of a mile farther north along the shore platform are outcrops of graywacke and pebble conglomerate, that here dip $30^{\circ}$ to $60^{\circ} \mathrm{NW}$. Intense shatter zones cutting across the platform imply faulting, but displacement is unknown.

Bedded tuffaceous sedimentary rocks crop out at the western tip of the island and along the south coast. At the westernmost point, fine-bedded argillitic rocks that strike N. $55^{\circ}$ E. and $\operatorname{dip} 65^{\circ} \mathrm{N}$. overlie conglomerate and coarse tuff. The conglomerate and tuff, which are exposed for about 100 feet along the shore to the southeast, in turn overlie laminated argillitic and tuffaceous rocks containing lime nodules elongated parallel to the bedding. A contact of argillite with a still older conglomerate strikes N. $60^{\circ}$ E. and dips $30^{\circ} \mathrm{NW}$. Locally the rocks are faulted and folded.

Age of the basement rocks.-Thin-bedded tuffaceous sediments crop out with conglomerate along the shore near Skoot Cove, and 


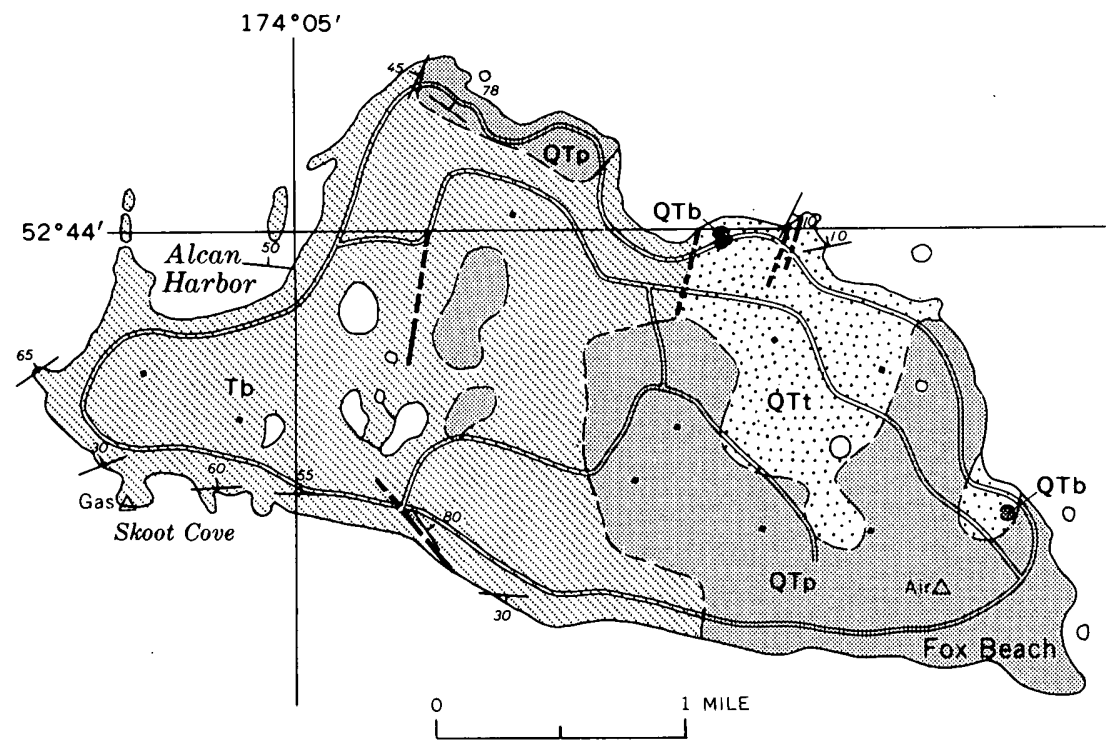

\section{EXPLANATION}

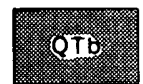

Basalt porphyry

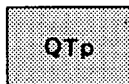

Hornblende porphyry

Includes some porphyry rich in plagioclase phenocrysts

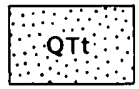

Andesitic and basaltic tuff and tuff-breccia

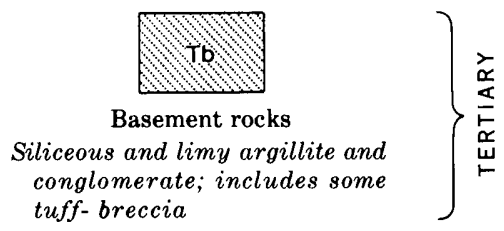

Contact

Dashed where approximately located

Fault

Dashed where approximately located; short dashed where fracture or fault is inferred from mapping or aerial photographs

$$
\text { Strike and dip of beds }
$$

Figure 115.-Geologic map of Shemya. 
a lime nodule from this series furnished the following diatoms, as reported by K. E. Lohman of the U.S. Geological Survey (written commun., Feb. 14, 1951) :

Actinocyclus sp. indet.

Actinoptychus senarius Ehrenberg

Coscinodiscus cf. C. radiatus Ehrenberg

Coscinodiscus cf. O. oculus-iridis Ehrenberg

Endictya robusta (Greville) Hanna and Grant

All these species are marine and have geologic ranges from Miocene to Holocene. Endictya robusta reached its heyday in late Miocene, and because it is also the most abundant diatom in this sample, an age of late Miocene can be tentatively assigned to this sample on this meager evidence.

Farther east along the shore are more conglomerates and tuffbreccias that also dip northward and northwestward. These and the ones previously mentioned contain abundant cobbles and fragments of hornblende-bearing lavas like those in the Massacre Bay and Faneto conglomerates of Attu.

\section{ANDESITIC AND BASALTIC TUFF AND TUFF-BREGCIA}

A sequence of bedded andesitic and basaltic tuff and tuff-breccia in the northeastern part of Shemya Island is especially well exposed in the shore platform north of the hospital area. The sequence is in fault contact with the basement rocks on the north shore, but because of its lack of folding and alteration it is regarded as distinctly younger than the basement rocks, possibly late Tertiary or early Quaternary.

The tuff and tuff-breccia are characteristically buff to brown to gray and occur in persistent beds a few inches to several feet thick which dip at angles of less than $20^{\circ}$ NW. Hornblende-bearing fragments are common, and abundant phenocrysts of both hornblende and pyroxene are found in some of the breccias. Some beds are light-gray feldspathic sandstones.

\section{HORNBLENDE 'PORPHYRY}

Hornblende dacite porphyry occurs in two areas in the central part of the island. A hornblende-poor dacite porphyry occupies the eastern end of the island and is exposed also in a small quarry in the north-central part and on the north coast.

Specimen 49By50 (table 1) is an intermediate rock type between the hornblenderich and hornblende-poor dacites from an outcrop about $1 \frac{1}{2}$ miles from the east end of the island and one-half mile from the south coast. It is a lightgray rock carrying numerous conspicuous black hornblende phenocrysts and white plagioclase phenocrysts. Under the microscope the abundant hornblende 
phenocrysts are seen to be somewhat frayed pleochroic green crystals, most of which are less than $1 \mathrm{~mm}$ long but a few of which are as much as $3 \mathrm{~mm}$ long. Concentric oscillatory zoning is revealed by slight differences in intensity of the green color and in extinction angle $\left(\mathrm{Z}: c=13^{\circ}\right.$ to $\left.15^{\circ}\right)$. Optic angles measured in the universal stage ranged from (-) $70^{\circ}$ to $76^{\circ}$. A ferw crystals of opaque oxide up to $0.1 \mathrm{~mm}$ in diameter are enclosed in some hornblende phenocrysts and distributed sparsely through the groundmass. The frayed edges of the hornblende phenocrysts are composed of a mesh of rods of clinopyroxene up to $0.05 \mathrm{~mm}$ long and opaque oxide crystals up to $0.01 \mathrm{~mm}$ in diameter. Stubby plagioclase phenocrysts up to $1 \mathrm{~mm}$ in diameter also are abundant. Extinction angles $\mathrm{X}^{\prime}: 010$ of $30^{\circ}$ to $35^{\circ}$ indicate anorthite contents of $\mathrm{An}_{46}$ to $\mathrm{An}_{56}$, according to curves for "high-temperature" plagioclase (Tröger, 1952, p. 113). The plagioclase phenocrysts show slight but distinct oscillatory zoning and, commonly, a sharp decrease of anorthite content at the extreme edge. The groundmass is composed of abundant small crystals of plagioclase (zoned oligoclaseandesine), many needles of clinopyroxene, and many grains of opaque oxide in a mesostasis of quartz(?) and a little orthoclase. The marginal conversion of hornblende phenocrysts to clinopyroxene-opaque oxide mesh is reminiscent of the opaque rims developed on the hornblende phenocrysts of some of the Massacre Bay lavas of Attu, which similarly carry pyroxene in the groundmass rather than hornblende.

\section{BASALT PORPHYRY}

The tuff and tuff-breccia are cut by a basaltic pipe that is excellently exposed in a roadcut in the shore slope near the middle of the north shore, and by another one near the eastern end of the island. The first pipe is probably about 500 feet in diameter, and the second may be only half as large. Both are composed of black fine-grained basaltic rocks with excellent columnar jointing perpendicular to the contacts with the surrounding tuffaceous rocks.

\section{STRUCTURE}

The basement bedded rocks in the western part of the island appear to have a consistent northerly or northwesterly dip ranging from $25^{\circ}$ to $65^{\circ}$. No fold axes were mapped. The bedded tuff dips more gently but still mostly northwestward. One of the few reverse dips noted was $10^{\circ} \mathrm{SE}$. on the north shore about in the middle of the shore-platform exposure of the bedded tuff.

The jointing in the basement rocks is intense, and in some places the rock is so fractured that during quarrying it breaks easily into fragments small enough for direct use as road metal. Undoubtedly many faults besides those shown on the geologic map (pl. 80) are present in the basement rocks. Joints are not as closely spaced in the rocks of the bedded tuff as in the basement rocks. 


\section{SURFICIAL GEOLOGY OF THE NEAR ISLANDS}

\section{By JOHN P. Schafer}

Little information has been published on the surficial geology of the Near Islands. Capps (1934) recognized that Attu had been heavily glaciated. Sharp (1946) described Agattu briefly and noted the evidence of former heavy glaciation, the abundance of turfbanked terraces, and the strong influence of rock structure on the topography of the island. Coats (1956) made observations on Attu and the Semichi Islands.

The present report describes the results of 5 weeks' fieldwork by the writer in 1950, principally in the middle part of Agattu from Armeria Bay and Patricia Bight south to Otkriti Bay, on Attu near West Steller Valley, Etienne Bay, and Massacre Bay, and on Shemya. This fieldwork was supplemented by the study of aerial photographs and by information obtained from other geologists who had been members of the field parties in 1949 and 1950. Especially important contributions to the discussion of shore features were made by Howard A. Powers and Olcott Gates. Alaid and Nizki Islands were not visited.

Of the three principal terrain types in the western Aleutians distinguished by Coats $(1956$, p. 86-88), two are represented in the Near Islands. The first type includes low-lying flat islands interpreted as raised wave-cut platforms and is represented in the Near Islands by Shemya and Nizki (Oubeloi). The second type includes mountainous islands of subaerial erosional origin, such as Attu. A combination of these two terrain types is shown by Agattu and Alaid.

The freshness of the glacial features of the Near Islands shows that there was extensive glaciation during late Quaternary time, presumably during the Wisconsinan Stage. This stage is the most useful time datum to which to refer geomorphic events. Events called pre-Wisconsinan may in part be early Wisconsinan or even pre-Pleistocene, but most of them are probably of pre-Wisconsinan age. Those called post-Wisconsinan occurred later than the uncovering of the islands by retreat of the Wisconsinan glaciers.

The present land surface of Attu cuts the late Tertiary or early Pleistocene Massacre Bay and Faneto Formations, described in the previous sections. Therefore, the development of the present landscape probably began after deposition of these formations. The Massacre Bay Formation includes volcanic rocks deposited under subaerial conditions, and pre-Wisconsinan marine terraces were cut on these rocks during an interval of submergence between the 
deposition of the rocks and the emergence of the terraces to their present heights above sea level.

The principal features of the Near Islands are pre-Wisconsinan. These older peaks, ridges, valleys, and marine terraces were strongly modified by glaciation, then altered in local detail by. postWisconsinan processes. The positions of many valleys were influenced by rock structures, especially on the Agattu plateau where most of the valleys, large and small, lie along fault or joint lines or are parallel to the strike of stratification. The subparallel trends of the main valleys on Attu also give evidence of fracture control. West of a line between Steller Cove and Abraham Bay there is a prominent northeast trend, and east of this line the main valleys trend east and east-southeast. A low fault scarp that extends along the west branch of West Steller Valley for more than $1 \frac{1}{2}$ miles is most likely the result of post-Wisconsinan movement along a fault that had determined the course of the valley in pre-Wisconsinan time. The general outlines of Attu and Agattu appear to be related to bedrock structural features, and many shoreline segments are parallel to conspicuous fracture lines inland.

\section{PRE-WISCONSINAN MARINE EROSION}

Terraces and plateaus, common on the islands, are mainly marine platforms that were cut as the islands underwent intermittent emergence during pre-Wisconsinan time. The changes in sea level may have been partly of glacial eustatic origin. Some terraces and plateaus were glaciated when Wisconsinan ice covered the islands, as is shown by glacial striations, till deposits, and landscape forms. The higher surfaces are less well preserved and are presumably older than the lower ones.

\section{ATTU ISLAND}

On Attu the pre-Wisconsinan marine terraces are seaward-facing shelves less than a mile wide. They are better preserved on the irregular south and northeast coasts than on the relatively straight north coast.

On the northwest side of Mikhail Point, marine erosion has cut a section through two south-facing terraces (fig. 116). The altitude of the upper terrace is $350-450$ feet, and that of the lower terrace is 100-200 feet. The rock platform of the upper terrace and the 300 -foot-high former sea cliff behind the terrace are covered by surficial deposits. The altitude of the sharp angle between platform and cliff, about 350 feet, is the most accurate indication of the amount of emergence of the terrace. The rock platform is nearly horizontal 
in the section, which is nearly parallel to the ancient shoreline in front of which the platform was cut. The lower terrace, which shows similar relationships, has emerged about 175 feet. The surficial deposits on these terraces were not studied in the field. At the west salient of a similar terrace at Chuniksak Point, the modern sea cliff exposes a considerable thickness of surficial deposits overlying a smoothly planed, sloping rock platform.

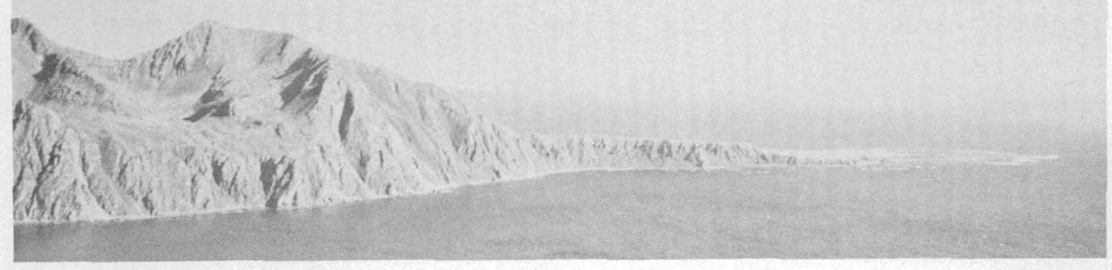

Figure 116.-Two raised marine terraces (center) transected by sea cliff, at Mikhail Point, Attu, from northwest. Modern shore platform at right. Inactive sea cliff is partly protected by turf-covered talus.

The topographic maps show comparable terraces at one or two levels on each of the points on the south shore of Attu. The maps show higher, more strongly dissected terraces at several places on the north shore, notably east of Austin Cove near Northeast Bluff, where there are three terraces between 500 and 1,750 feet above sea level. Some of these terraces are conspicuous in views from the sea.

\section{AGATTU ISLAND}

A rolling plateau (fig. 117) constitutes about three-fourths of the area of Agattu Island. The mountains of the northeastern part of the island rise above the plateau along a nearly straight scarp that faces southeast for most of its length. The fact that several bedrock contacts cross the scarp from mountains to plateau without displacement (pl. 81) shows that the scarp is primarily erosional. Both the plateau and the scarp cut across a variety of rock types and structures. The plateau is believed to be a raised wave-cut platform, and the scarp a former sea cliff.

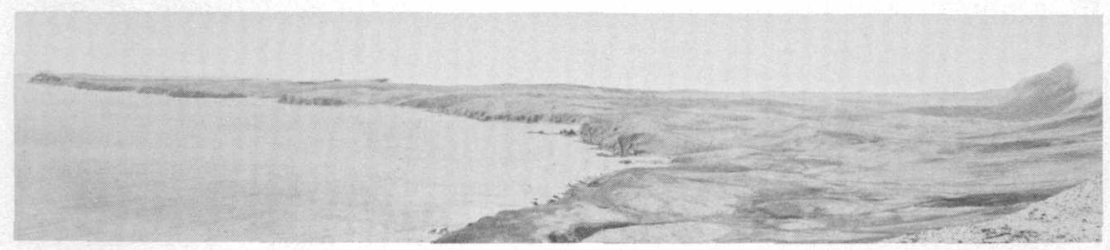

Figure 117.-The plateau on Agattu, viewed southwest from peak AGAT. Cape Sabak at left. 
The plateau has undergone considerable glacial and fluvial erosion since it was raised above sea level, and it is cut by valleys $50-400$ feet deep. The actual wave-cut rock surface and any marine deposits that once lay on it have been entirely destroyed, as far as is known. The plateau has a maximum width of 7 miles and a length of about 14 miles. It slopes upward to the northwest from an altitude of about 300 feet near Cape Sabak to 400-600 feet at the foot of the mountain scarp, and to more than 850 feet in places near the west end of the island. A 950-foot-high hill $11 / 2$ miles southeast of Armeria Point probably was a tiny island at the time the plateau was being cut by marine erosion.

Terraces preserved on spurs on the north side of the mountains are about 100 feet above the plateau just south of the mountains. It is not known whether the age of these terraces is different from that of the plateau, or whether they are of the same age but were raised to a higher position by differential uplift.

Narrow pre-Wisconsinan terraces at Gillon Point, Armeria Point, and several other places are lower and younger than the plateau. The most extensive of these extends from Gillon Point to West Cove and is about a quarter of a mile wide and 50-200 feet above sea level.

\section{SEMIGHI ISLANDS}

Of the three islands in the Semichi group, Shemya and Nizki are low islands, and Alaid is partly low and partly hilly. Only Shemya was visited by members of the field parties, and most of this discussion refers to it. The surface of Shemya is a gently rolling low plateau about 2 miles wide and 4 miles long. It slopes rather uniformly to the southwest and south-southwest, from altitudes of 200-275 feet at the crest of the north shore cliffs down to 25-75 feet along the south shore, at an average rate of about 125 feet per mile. The southwest corner of the island stands above the adjacent sloping surface. The shallow basins and valleys on the island are mostly in a mantle of surficial materials.

Excellent exposures are provided by two deep quarries northwest of the center of Shemya, at an altitude of about 200 feet. In the west quarry the bedrock surface is exposed for a distance of more than 500 feet (fig. 118). Its profile is almost straight; the only conspicuous irregularity is a sag about 3 feet deep at the contact between two rock types (fig. 118, left). The bedrock surface slopes gently to the southwest, and where it has not been shattered by weathering it is sharply knobby and cuspate and has a relief of a foot or less. The knobs and cusps, whose forms are controlled by jointing in the rock, 
have smoothly worn and locally polished surfaces. This kind of surface, shown at many places on modern wave-cut platforms along the present shoreline, is very unlike the rounded stoss-and-lee surfaces cut by glacial erosion. In the west quarry, bedrock is overlain by 3-10 feet of sand and boulder gravel. In the east quarry both the bedrock surface and overlying materials are like those in the west quarry. In the cliffs of the north shore the bedrock surface is less well exposed, but it seems generally similar to that of the quarries.

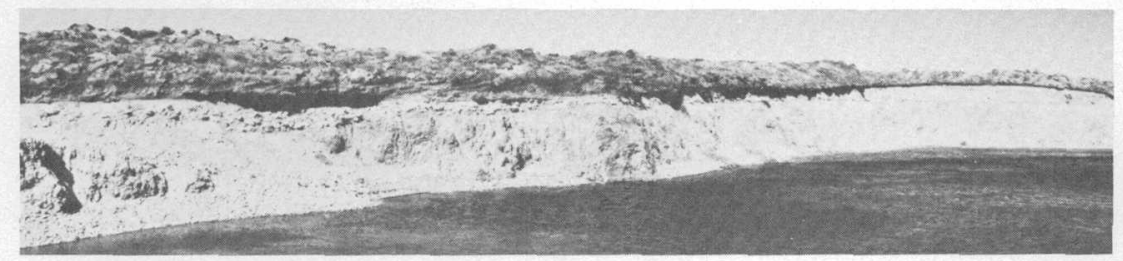

Figure 118.--Raised marine platform overlain by gravel, sand, peat, and spoil in western quarry, Shemya; viewed from southwest.

The bedrock surface of Shemya is certainly a wave-cut platform. It is most likely of pre-Wisconsinan age, because a considerable period of stability of sea level must have been required to cut it, and because glacial till is exposed in many shallow excavations on the higher part of the island. The gently rolling lake-dotted surface of the whole island has a glaciated appearance. A small exposure of the bedrock surface at the west end of the west quarry shows about 1 square yard of ice-eroded form, different from the wave-worn surface of all other exposures. Striations on this ice-eroded surface indicate that glacial ice moved from west to east. Striations are present also on some of the boulders in the gravel at both quarries.

No explanation of these facts seems completely satisfactory, but the interpretation favored by the writer is as follows. The bedrock platform of Shemya was cut by marine erosion, covered by marine deposits, and then glaciated. The marine deposits were partly removed by glacial erosion, which in at least one place cut into wave-cut bedrock surface. Till was deposited in some places, principally on the higher part of the island. Outwash sand and gravel were also deposited, covering the one known area of glaciated bedrock surface. This hypothesis requires that where the distinctively waveworn bedrock surface is not glacially eroded, at least the lower part of the overlying sand and gravel must be marine and must have protected that surface from glacial erosion. However, no unconformity was seen in the extensive exposures of sand and gravel to support the idea of separate glacial and marine deposits. At no 
place could the relationship of the till to the sand and gravel be seen, but the till is inferred to be younger than the supposed marine deposits, and it is certainly younger than the marine planation of the platform.

According to Coats $(1956$, p. 86$)$, Shemya was not glaciated after the platform was cut by marine abrasion, and the sand and gravel are marine, perhaps reworked from glacial material. This hypothesis is opposed by the available evidence, which shows that glaciation occurred after marine planation.

Nizki Island and the lowland part of Alaid Island are at altitudes below 200 feet; they resemble Shemya and probably are marine terraces of similar age. The area of 600 -foot-high hills at the west end of Alaid must have been a small island when the terrace was cut.

\section{TERRACE CORRELATIONS}

Clearly, the different islands, and even different parts of one island, have not had the same history of changes of level, but probably have been affected by local and differential crustal movements. Possible groupings of the pre-Wisconsinan terraces may be suggested on the basis of degree of preservation. On the Shemya platform. (fig. 118) and probably on some of the lower terraces of Attu (as at Mikhail Point, fig. 116), parts of the original marine platforms are preserved under surficial depositc. These terraces are presumably younger than deeply dissected terraces, the original wave-cut rock surfaces of which have been entirely destroyed by later erosion. Among these young terraces are the plateau and terraces of Agattu, and probably the high terraces of the north shore of Attu.

\section{GLACIATION}

\section{GLACIAL EROSION}

The mountains of Attu and Agattu display the typical land forms of valley glaciation: cirques show a wide variety of shapes and sizes, almost all valleys have distinct rock steps at their mouths, and some valleys contain lakes. On Attu, the great majority of cirque floors lie between altitudes of 1,000 and 2,250 feet. In places where preglacial valley heads were lower, as on the Chirikof Point peninsula, a few cirque floors are as low as 500 feet. The mountains on Agattu are smaller in area and lower than those on Attu; the cirque floors there are also lower and range in altitude from about 1,100 down to 275 feet. The scarp at the west end of the Agattu plateau is cut by cirques whose floors lie at altitudes of 100-300 feet 
on the pre-Wisconsinan marine terrace. The height of valley heads controlled the level of cirque development; the lower cirques probably came into existence later than the higher ones, as snowline became lower.

The mountain valleys of Attu and Agattu are glacial troughs, most of which show conspicuously $U$-shaped cross sections, somewhat modified by stream and frost action. Almost all cirques and tributary valleys hang above the main troughs, and the longitudinal profiles of troughs generally show rock steps. The submerged troughs of Attu are shallow and lack sills and are not fiords.

Benches and grooves are common on the sides of glacial troughs, particularly on Attu. The different origins of such forms were discussed by Cotton (1942, p. 236-241, 250-252, 284-299). (1) West Steller Valley, Attu, and the valley south of Binnacle Bay, Agattu, display benches which correspond in position to relatively resistant beds of sedimentary rock or to sheets of igneous rock. (2) The southwest side of Gilbert Ridge, Attu, shows conspicuous adjacent coalescing cirque floors at accordant levels. (3) In some of the valleys on the south side of the Attu Mountain-Martinez Mountain ridge (studied only on topographic maps and aerial photographs), welldeveloped valley-side benches resemble remnants of dissected valley floors. (4) Some uneven benches west of lower Steller Valley, south of Abraham Valley, and elsewhere on Attu, as well as on Agattu appear to represent spurs that were truncated by glacial erosion. Extensive benches which may be of this origin lie south of the lower parts of the Temnac and Kaufman Creek valleys. Some ridges seem to have been completely overwhelmed by ice and were beveled to form plateaulike areas, such as those between East and West Massacre Valleys, between the two main branches of West Steller Valley, and east of Earle River. (5) The walls of many troughs have conspicuous large furrows (fig. 119) which do not seem to be explainable in any of the foregoing ways.

Many passes on Attu and Agattu are broad, smooth floored, and U-shaped. Cotton (1942, p. 192-193, 234) attributed such glaciated passes to glacial diffluence (as distributary ice streams spilled through notches in valley sides) and transfluence (diversion of ice headward from cirques across a divide, through a col cut perhaps by intersection of cirques). Almost all valleys on Attu, except small tributaries, are joined with one or more valleys by glaciated passes. Broad low passes, such as those which connect Temnac Valley with Abraham and Peaceful Valleys and which join Massacre, Siddens, Jim Fish, and O'Donnell Valleys, are diffluent passes. Many of these 


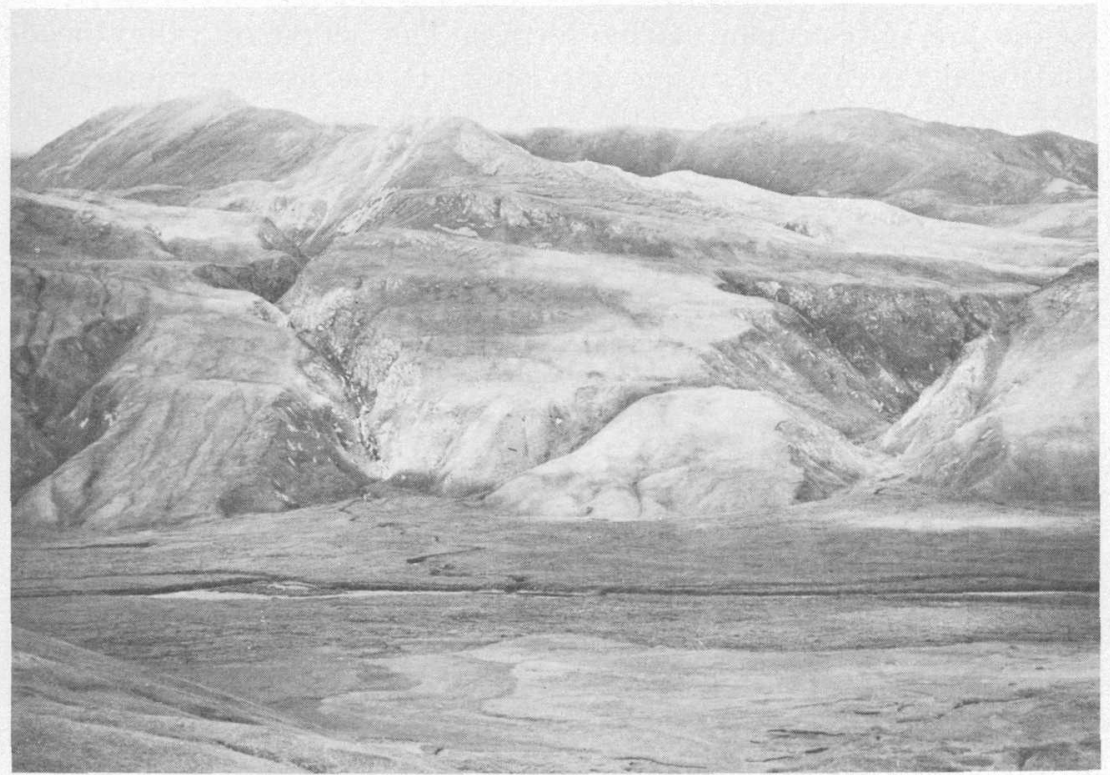

Figure 119.-Furrowed trough wall, postglacial gullies, and alluviated valley floor in West Steller Valley, Attu; viewed from southeast.

seem to lie along major lines of bedrock weakness and probably were passes before glaciation. Ice from Temnac Valley overflowed a col in the ridge to the south and cut a conspicuous pass to the lower valley of Kaufman Creek. Transfluent passes also are numerous and range in altitude from below 350 feet on the Chirikof Point peninsula to above 2,250 feet on the Attu Mountain-Martinez Mountain ridge. All seven passes across the main southwest-northeast divide of the Agattu mountains have been glaciated. Striations and stoss-and-lee topography show that ice flowed southeast through the passes on both sides of Peak F and spread out as it descended onto the plateau. The ice divide evidently lay somewhat northwest of the topographic divide.

Several occurrences of striations indicate that the ice moved generally southward on the Agattu plateau south of the mountains and spread to the southwest and east. The hundreds of lakes and ponds on the plateau are believed to be of glacial origin, except for some small ones which were formed by frost action and vegetation. Few lakes were studied closely, but several are known to lie in rock basins. The ice sheet that covered the plateau must have spilled over the marginal slopes on all sides. In many places the upper parts of the slopes show evidence of glacial erosion, but between Nile Point and Aga Cove almost none of the ice-rounded margin has survived post- 
glacial marine erosion. The cirques in the scarp at the west end of the plateau were cut mostly before the ice sheet reached its maximum extent, as is shown by ice-rounded parts of the crests of the cirque headwalls.

Only a small part of the emerged rock platform exposed in the quarries on Shemya was glacially eroded (as previously described). It seems likely, therefore, that the ice sheet that covered Shemya and probably Nizki and the lowland part of Alaid was relatively thin and did not strongly erode these islands.

Easily eroded bedrock (weathered or hydrothermally altered in pre-Wisconsinan time) exposed at several places in the Massacre Bay lowland of Attu shows that the glaciers that emerged from the adjacent valleys did not everywhere cut down to resistant rock.

\section{GLAGIAL DEPOSITION}

There are few exposures of glacial deposits in the Near Islands besides those in the quarries and roadcuts on Shemya and near Massacre Bay on Attu. The bedrock of the peaks, hills, and ridges of mountainous areas and of the Agattu plateau is covered by a thin and discontinuous mantle of frost-shattered material derived from the bedrock. Glacial deposits are mostly in valleys and lowlands and are generally concealed by the extensive blanket of turf and peat. Much material carried by the ice was probably deposited in areas now below sea level. Scruton (1953) concluded that a hummocky stony area in the bottom southeast of Massacre Bay is covered by glacial morainic deposits.

Glacially transported boulders are locally common, and in a few places the distribution of erratics shows the direction of ice motion. An example on the Agattu plateau is the gabbro boulder fan that extends at least 2 miles to the south-southwest from the southeast flank of Peak E, where a gabbro sill was strongly eroded by ice that emerged from the adjacent glaciated pass.

Till exposed in an old roadcut near the northeast corner of Karab Cove, Agattu, is about 15 feet thick. It is yellowish brown and is composed mostly of sand and silt, with less than 5 percent stones and probably little clay. Most of the stones are subangular and many are striated. Similar light-gray to yellowish-brown till is extensively exposed in excavations in the Massacre Bay area of Attu and on the higher part of Shemya. At least part of the surficial material which covers the old marine terraces of Attu appears to be till. Some hummocky bouldery areas in such places as the plateaulike glacially truncated ridge in the upper part of West Steller Valley on Attu. are underlain by till. 
Moraines occur in many cirques on Attu, but in only a few valleys below, and none are on Agattu or Shemya. One distinct valley moraine forms the dam of a lake on Addison Creek, 3 miles upstream from West Arm of Holtz Bay, at an altitude of about 400 feet. Some moraines are shown on the geologic map of Attu (pl. 80), and many others doubtless exist. Several cirques around the head of West Steller Valley contain two moraines each. The outer moraines lie in the mouths of the cirques at altitudes of about 1,500 feet. They. reach heights of more than 100 feet in places, and some have ponds on a hummocky topography. The outer moraines and the areas within them bear only scattered vegetation, whereas the valleys below are almost completely vegetated. Above these moraines and close to the cirque headwalls are low debris ridges at altitudes of 1,700 to 1,900 feet, with very little vegetation. The small sizes of some of the ridges and of the basins within them suggest that they have been formed by movement of debris over large perennial snowbanks, thus that they are protalus ramparts rather than moraines. These inner ridges clearly are very young, and perhaps they are equivalent in age to the moraine 0.2 mile in front of one of the existing glaciers about halfway between Attu Mountain and Martinez Mountain, at an altitude of about 1,500 feet. One or two moraines are present in many cirques around Etienne Bay. A third, lowermost moraine, extending down to an altitude of about 800 feet, is present in the large compound cirque on the north side of the head of Etienne Bay.

Large amounts of glacial outwash probably underlie the postglacial alluvium deposited by streams in the broad, flat-floored valleys of Attu. Some outwash is now being deposited in the valleys of streams draining from the existing glaciers of central Attu. Perhaps some of the sand and gravel on the Shemya platform (previously described) is outwash.

\section{GLACIAL HISTORY}

The relatively small amount of weathering and erosion of glacial features of the Near Islands suggests that the features are no older than Wisconsinan. No clear evidence of pre-Wisconsinan glaciations has been found, and if they occurred, their effects were masked or destroyed by those of intense glaciation during Wisconsinan time.

The general form of the ice surface at the time of maximum recorded thickness of Wisconsinan ice can be reconstructed from the present topography. Cirques and glaciated passes, with allowance for reasonable thicknesses of ice in them, give minimum local altitudes of the glacier surface. Sharp-crested peaks and aretes stood 
above the ice and indicate upward limits of altitude of the ice surface. At the glacial maximum, only high peaks and ridges stood above the ice surface on Attu; large ice streams were connected through passes in the mountains and were confluent over and around the ends of ridges to form a continuous seaward slope of ice. Glacier heads along high ridges were at altitudes of more than 2,000 feet in some places, and some of the main valleys in the central part of the island were probably filled with ice to depths greater than 1,000 feet. In outlying groups of peaks, glacier heads were commonly at 1,000 to 1,500 feet or even lower.

Ice was confluent around the peaks and ridges of the Agattu mountains also, and extended south and west as a plateau ice sheet that perhaps had a hump over an independent center of growth on the western part of the plateau. All the secondary divides of the Agattu mountains are sharp aretes, but the passes across the main divide were glaciated. The ice thickness as inferred from sharpcrested peaks and aretes is not certainly the absolute maximum thickness. Peaks and ridges might at one stage have been completely overridden and later resharpened by erosion during glacier shrinkage. The evidence suggests that the ice surface (excluding small hanging glaciers) at the time the aretes were being formed was at altitudes of 1,000 to 1,200 feet in the main cirques in the central and western parts of the range. Probably nowhere was the ice in the mountains as much as 1,000 feet thick. There is no direct evidence of the thickness of the ice sheet on the plateau. Because of the ease with which ice could flow off the plateau, however, especially to the south, and the lack of evidence of glaciation above an altitude of about 1,200 feet in the mountains, the ice sheet may have been only several hundred feet thick, and certainly it was less than 1,000 feet thick.

The Semichi Islands, with the possible exception of the hills on Alaid, were covered with ice, probably a single confluent sheet. The presence on western Shemya of striations made by ice flowing eastward suggests that the center of movement of this ice sheet was west of Shemya.

The snowline at the glacial maximum in the Near Islands was probably somewhat above the floors of the lowest cirques, perhaps near 600 feet, some 1,700 feet lower than at present. The smaller part of the ice from the Agattu mountains moved onto the plateau and was most likely inadequate to maintain the ice sheet that covered the plateau. As suggested by Sharp (1946, p. 198), the snowline probably dropped low enough to nourish directly the surface of the plateau ice sheet. 
Sea level was affected during the glacial maximum by eustatic emergence, by isostatic subsidence beneath the weight of ice, and perhaps by diastrophic movement. According to Gates and Gibson (1956, p. 138), the net emergence of the Near Islands platform was probably at least 240 feet. The margins of the ice masses of Attu, Agattu, and the Semichi Islands extended unknown distances beyond the present shores of the islands. Scruton (1953) concluded that these ice masses coalesced to form an ice sheet that covered most of the Near Islands platform. Possibly, most of the submarine deposits on which his conclusion was based could have been deposited by ice rafting.

Some cirque moraines on Attu and the low-altitude moraine in Addison Valley formed with glacier fluctuations during general recession of the ice. There is no evidence of such fluctuations on Agattu and Shemya. Readvance and recessional moraines are known from many districts on the mainland of Alaska, but correlations with those on Attu do. not seem feasible at present. The moraine in front of one of the existing glaciers on Attu and the probably correlative highest moraines and protalus ramparts of the Steller Bay area are considerably more recent. They may have formed during the glacier readvance during the last few millennia. The present small size of the Attu glaciers suggests that the former glaciers may have completely disappeared here during the postglacial warmth maximum, and that the existing glaciers are of more recent origin. The nearest area where such glacier fluctuations have been described in detail is in the Prince William Sound region of south-central Alaska (Cooper, 1942). Comparable recent fluctuations of small glaciers probably occurred on Great Sitkin Island (Simons and Mathewson, 1955 , p. 33).

Small glaciers still exist in cirques of the Attu Mountain-Martinez Mountain ridge in central Attu, the only peaks in the Near Islands that reach altitudes of more than 3,000 feet. The largest of the more than a dozen glaciers here has an area of slightly less than half a square mile. None of the glaciers were visited in the field, but crevassed glacial ice is unmistakably shown in aerial photographs. The lower ends of the glaciers lie at altitudes between 1,500 and 2,000 feet, and the firn lines on them, presumably representing an orographic snowline, are most likely at altitudes between 2,000 and 2,300 feet. 


\section{POSTGLACIAL STREAM ACTION}

\section{EROSION}

The main valleys in the Near Islands are preglacial stream valleys modified by glaciation, as previously described. Postglacial stream erosion is conspicuous in some places, but it has significantly affected only a small part of the surface area of the Near Islands. Tributaries to gullies are poorly developed, owing to the dominance of mass wasting over runoff erosion. Rainwash erosion is probably inhibited in most places by the heavy turf or the permeable frostbroken rubble which covers most slopes. On Attu, postglacial streameroded V-shaped gullies are numerous (fig. 119) and range in depth from a few feet to 200 feet, and rarely to 400 feet. They are largest where streams cross such convexities as the rock steps in valley floors and the lips of cirques and hanging valleys both inland and above wave-cut cliffs. In most large valleys, incised parts alternate with only slightly eroded or even aggrading parts. Valley widening has produced some narrow flood-plain segments. Linear gullies have been eroded along some of the postglacial faults on Attu, as well as along preglacial lines of bedrock weakness. Very small gullies, incised only a few feet, have been cut by local slope runoff. Vegetation commonly covers the gully walls and, in places, floors, and erosion seems to be slow; some gullies wander among frost-produced minor relief features or are partly dammed by masses of frost-moved material. Small gullies grade into ungullied drainage lines marked by stripes of relatively dense vegetation (fig. 119, left-hand side).

On Agattu, postglacial gully development is similar to but not as extensive as that on Attu. Little stream erosion has occurred on the Semichi Islands because of their small area and slight relief.

\section{DEPOSITION}

The principal postglacial deposits in the Near Islands are in the broad valleys of Attu, with which the following discussion deals principally. The alluviated floors of the valleys slope 25-100 feet per mile, and exposed sediments are gravel and sand, locally veneered with silt. The streams in most of these valleys follow simple sinuous channels, but those in a few valleys have braided courses. Much of the valley fill may be glacial outwash.

At the seaward ends of the alluviated valleys are large bayhead beaches. Even in the most protected of the large bays, wave and current action are strong enough to prevent formation of deltas. The flat valley in Etienne Valley between Etienne Lake and the head of the bay has been built almost entirely by prograding of a midbay 
bar. The presence of groups of old beach and dune ridges in other valleys, locally more than a mile inland from the present heads of the bays, suggests that prograding of beaches may have been a major agency of deposition in at least the seaward parts of some alluviated valleys. Stream-carried detritus is contributed to a bayhead beach, but a lagoon cuts off most of the supply of sediment to a midbay bar from the main stream of a valley.

Substantial deltas are built only where main streams enter lakes, and most of the lakes on main streams are bayhead lagoons, as at Etienne Bay. The great majority of lakes receive very little sediment from the small streams which enter them.

Alluvial fans commonly have been built where steep tributaries enter the main valleys of Attu, especially along the sides of broad alluviated valleys (fig. 119 and pl. 80). The fans extend half to three-fourths of the way across the floors of some valleys, as in the upper part of Temnac Valley. Fan-shaped detrital accumulations range from aluvial fans to talus cones. Alluvial flats on the treads of some rock steps may represent filled lake basins. Narrow floodplain and low terrace segments occur locally.

On Agattu, stream deposits include alluvial fans in the mountains and small flood-plain segments along some streams. Stream deposits are almost absent from the Semichi Islands.

\section{POSTGLACIAL MARINE ACTION}

The effects of postglacial marine erosion and deposition are abundantly displayed in the Near Islands group, and the features discussed here include sea cliffs, shore platforms, and beaches. Steep sea cliffs dominate the shorelines of all the islands. Shore platforms are generally narrow around Agattu, Shemya, and parts of Attu, but they are especially well developed in places along the south coast of Attu and reach a maximum width of a quarter of a mile at one place on Chuniksak Point. Broad beaches are common at the heads of bays on Attu; they are less common on Agattu and almost lacking on Shemya. Raised cliffs, platforms, and beaches occur in some places. Many coves, gullies, short segments of cliff, and margins of stacks are eroded along fault zones in bedrock.

\section{MARINE EROSION}

\section{SEA CLIFFS}

The shoreline of Attu is about 160 miles long, and about 145 miles of this is cliffed. The highest sea cliffs of the Near Islands are on the sides of partly submerged glacial troughs of Attu (fig. 116), where 
a relatively small amount of marine erosion of the steep trough walls has produced very steep, craggy, unstable slopes to heights of as much as 1,500 feet. In front of most of the active cliffs are boulder beaches, bare shore platforms, or small taluses, but a few sheer rock faces plunge directly into the sea. Most of the cliffs of Attu are not being actively attacked at present and are largely covered by colluvium, taluses, and vegetation. The bases of these inactive cliffs are separated from the active shoreline by partly turf covered taluses (fig. 116), colluvial benches (fig. 120), or broad boulder beaches. The relatively recent origin of the inactive cliffs is shown by their sharp profiles and by the many hanging stream valleys. Similar inactive cliffs have been produced at the heads of partly submerged glacial troughs, where alluvial or prograding beach deposits now bury cliff bases.

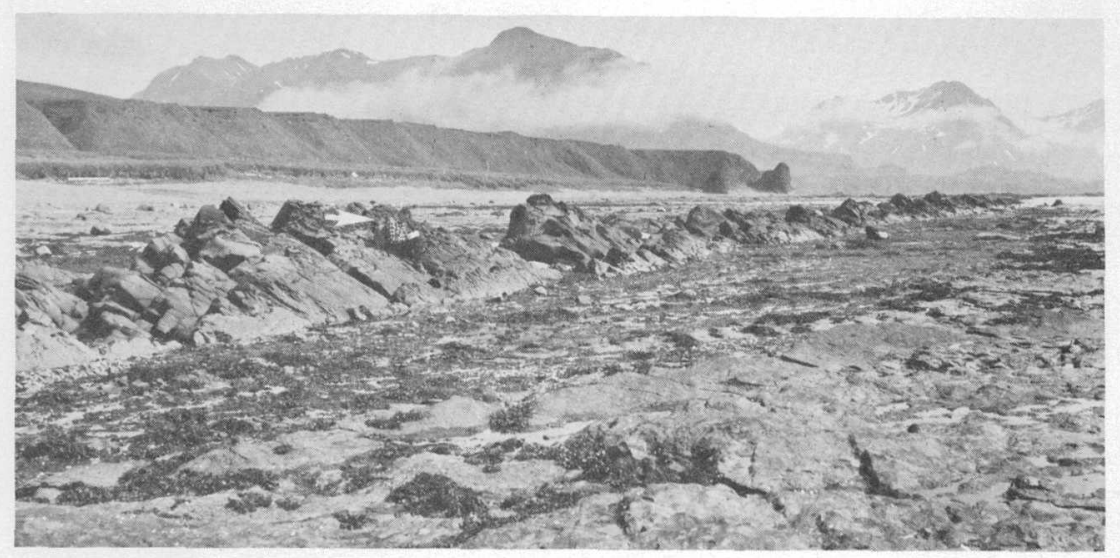

Figure 120.- Shore platform, inactive sea cliff, and colluvial bench at foot of cliff, Chuniksak Point, Attu; viewed from west. Ridge on platform is outerop of basic dike. Scale is shown by man at left of center.

The sea cliffs of most of the south coast of Agattu are active. In many places they stand vertically, or nearly so, and are as much as 400 feet high. Remnants of ice-rounded slopes along the cliffed edges of the Agattu plateau, as at the west end of the south coast and on the northern part of the east coast, show that the cliffs at those places were probably produced by relatively slight marine erosion of glaciated scarps, which were in turn developed from preglacial sea cliffs. The marine planation that produced the insular shelf 5-8 miles wide south of Agattu (Gates and Gibson, 1956, pl. 1) was certainly mostly pre-Wisconsinan. Most of the cliffs of the north coast of Agattu are 
inactive (fig. 121). Aleut habitation sites, marked by collapsed huts and by middens 5-10 feet thick, lie on colluvial benches in front of inactive cliffs in several places, as at Binnacle Bay and Patricia Bight. Because these sites most likely date from before the great decrease of population in the late 18th century (Collins and others, 1945, p. 12), the cliffs and benches must have been stable for at least a few centuries. Wave attack on the inactive cliffs has been arrested for so long that it cannot be considered a present-day process.

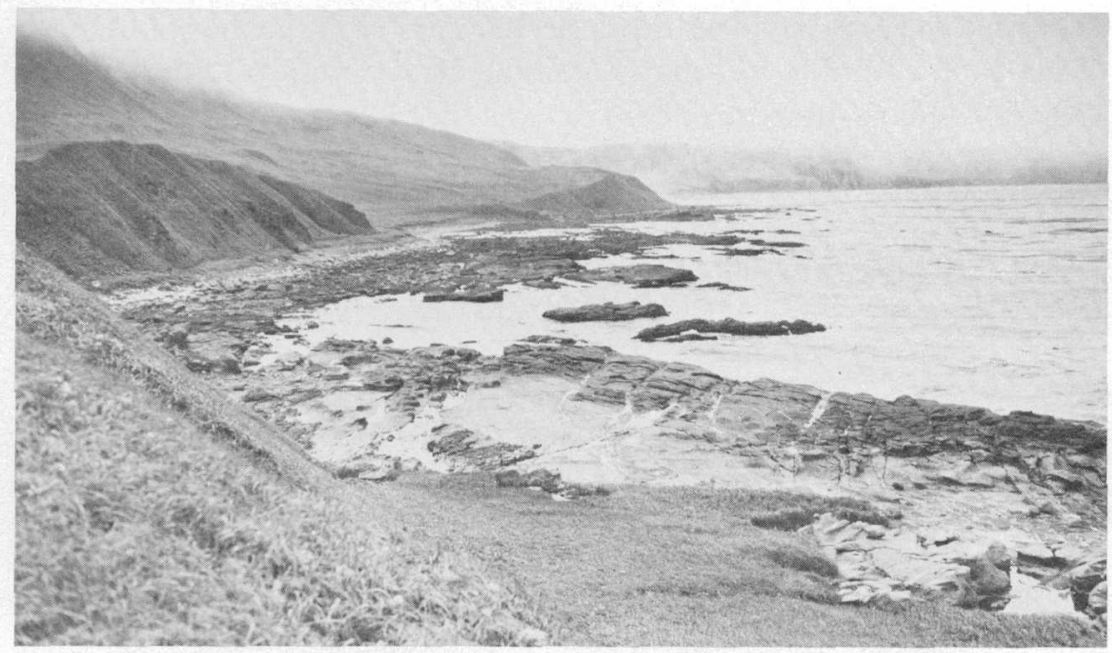

Figure 121.- Shore platform, inactive sea cliff, and colluvial bench at foot of cliff on east shore of Armeria Bay, Agattu; viewed from north.

The most likely cause of cessation of wave attack on the nowinactive cliffs is a slight tectonic or eustatic emergence. This temporarily moves the line of storm-wave attack out from the bases of most cliffs, until deepening of the nearshore bottom is accomplished. Sea cliffs near Wellington, New Zealand, for instance, became inactive as a result of a 5-foot earthquake uplift in 1855 (Cotton, 1951, p. $109-110 ; 1952$, p. 466).

\section{SHORE PLATFORMS}

Conspicuous shore platforms, cut almost horizontally across bedrock near sea level, lie in front of many of the wave-cut cliffs of the Near Islands. These platforms are distinct from the conventional sloping wave-cut profile of equilibrium defined by Fenneman (1902) and Johnson (1919, p. 160-163), and recently described by Bradley (1958, p. 426-430). In the Near Islands such conventional wave-cut benches most likely are represented by many of the extensive shallow 
benches below low-tide level that may be seen on vertical aerial photographs.

In contrast, the shore platforms are remarkable because they are cut so cleanly across bedrock; their nearly horizontal surfaces, commonly having less than a foot of relief, are widely exposed at low tide. The bedrock geology of a narrow shore platform on Casco Point, Massacre Bay, has been described in detail in an earlier section (fig. 111). (A shore platform is also shown in the profile of the south coast of the Murder Point peninsula, Massacre Bay, fig. 122.) The broadest platform, cut on bedded argillitic rocks at the tip of Chuniksak Point, Attu (fig. 120), reaches a maximum width of a quarter of a mile. Other broad shore platforms occur on all the promontories on the south coast of Attu and locally along the north coast.

At Chuniksak Point, Attu, the bedded argillites and related sedimentary rocks of the Chuniksak Formation dip $15^{\circ}-20^{\circ}$ seaward and are cut by dikes and sills of diabase. The local microrelief of the platform is approximately proportional to the thickness of the bedding: where the beds are thin the platform is remarkably smooth, and where they are thick they form low homoclinal ridges. At high tide most of the platform is awash. Where an active cliff stands behind the platform, a narrow sloping ramp that is not submerged at ordinary high tide commonly lies between the platform and the base of the cliff. Dikes and sills of diabase stand as prominent ridges several feet high (fig. 120), and there are also some stacks on the platform. At low tide the platform emerges except for long narrow embayments eroded along fractures. Much of the surface is covered by algae, and marine animals are abundant in shallow pools.

On Agattu, shore platforms were examined in parts of Armeria Bay (fig. 121), Binnacle Bay, Patricia Bight, and Karab Cove, and. they are present on many other parts of the island. The shore platforms of Agattu, like those of Attu, are almost flat but have minor irregularities related to bedrock structure and lithology. The platforms are as much as 300 feet wide. Their seaward margins in most places are abrupt nips 6 or more feet high; these nips are the lowtide shoreline cliffs, but they are under water at high tide. All the platforms studied are cut on bedded rocks that dip less than $15^{\circ}$. At Patricia Bight the rocks strike at a considerable angle to the shoreline, so that the platform at low tide consists of a series of parallel ridges and intervening water-filled troughs trending seaward. On the seaward edges of the platforms cut on landward-dipping rocks on the east shores of Armeria and Binnacle Bays, broad ramparts of massive tuff stand 2-5 feet above the general level of the platforms and in places are not covered at ordinary high tide. In the Karab 
Cove area, well-bedded rocks dip seaward, and the platforms cut on them lack ramparts and generally slope very gently seaward. With the exception of beaches in front of some cliffs, there is very little detrital cover on the shore platforms. The cliffs behind many platforms are inactive. Where cliffs are active, the rock of the upper parts of the cliffs is somewhat weathered, but the rock of the lower 5-15 feet is generally smoothly abraded and unweatherea.

The shore platforms of the Near Islands show close similarities to those along the coasts of New Zealand, Australia, Hawaii, and other parts of the world, the origin of which has been much discussed but with little agreement. Those of New Zealand and Australia, variously called shore platforms, shore benches, or storm-wave platforms, have been described and discussed by Bartrum $(1916,1926)$, Edwards (1941, 1951), Hills (1949), Jutson (1939), and others. Those of Hawaii have been described and discussed chiefly by Wentworth and Palmer (1925), Wentworth (1938), and Stearns (1941). Some of the platforms described in these papers may be different in origin from those of the Near Islands, but the descriptions from many areas could be applied almost without change to Near Islands platforms.

The principal point at issue in most of the discussions of origin of platforms is the relative importance of subaerial weathering and wave erosion as agents of planation. For Hawaii, Wentworth (1938) concluded that "water-level weathering" at the margins of shallow pools reduces wave-cut sloping platforms to horizontal platforms. For Australia, Hills (1949) adopted a related hypothesis of "waterlayer weathering" caused by alternate wetting and drying of the rock just above water table. In both areas, of course, the decomposed or disintegrated rock is removed by the action of waves and currents. Hills maintained that waves acting alone cannot concentrate their attack at a particular level and would cut a sloping, not a horizontal, surface. This sloping surface would be the "profile of equilibrium" of Fenneman (1902) and Johnson (1919). On the other hand, Bartrum (1926) distinguished two types of platforms: those formed in a way similar to that described by Hills, and those cut by storm waves on exposed coasts. Cotton (1952, p. 413-417) made a similar distinction, and Edwards (1941, 1951) discussed in detail the storm-wave origin of platforms.

The shore platforms of the Near Islands were developed probably by a combination of subaerial weathering and wave erosion. Subaerial weathering is effective down to the level of permanent water saturation, near the upper limit of rank growth of seaweed. In contrast to processes in the mild climates of New Zealand, Australia, and Hawaii, the chief weathering agent in the Near Islands may not be 
chemical decay but, rather, shattering by frost action. Frost-loosened and wave-quarried debris is swept off by storm waves, which abrade and smooth the platform surface but probably do not quarry out much rock below the level of alternate freezing and thawing.

The low-tide nip at the seaward margin of a platform is eroded by quarrying and abrasion. However, during formation of a platform, the main cliff must be cut back more rapidly by the combination of storm-wave attack and weathering than the low-tide nip is cut by wave attack alone. The absence of shore platforms on the large gabbro masses of the main headlands of Agattu is explained by the fact that the sparsely jointed gabbro is disintegrated much less rapidly by wave or frost action than are the bedded sedimentary and volcanic rocks.

Because the present platforms on the major part of the Near Islands shorelines stand in front of inactive sea cliffs, it is inferred that the platforms (a) were cut nearly at their present levels when the cliffs were active; (b) were raised slightly during the emergence that inactivated the cliffs; (c) have been eroded to their present midtide levels by weathering and abrasion, except for remnants that stand near or above high-tide level; and (d) are now being slowly removed by wave attack at the low-tide nip.

\section{MARINE SHORELINE DEPOSITION}

The large bays on Attu are partly submerged glacial troughs with nearly parallel sides. At their blunt heads are large bars or beaches, mostly of sand. The bay heads were once considerably farther inland in these troughs; for example, old abandoned sea cliffs, partly buried by alluvium and talus, extend along the valley walls about $11 / 2$ miles inland from the present heads of Auburn Cove (west part of Steller Cove) and Etienne Bay. Midbay bars have enclosed large lagoons in some bays which receive little land drainage, such as Etienne Bay and Sarana Bay. The heads of most of the bays have gradually prograded by the deposition of beach material and stream alluvium, as in Steller Cove and Abraham Bay. Old shore ridges that mark former positions of the heads of bays stand above the alluvium. The crests of some of these old ridges are notably higher than the modern ridges in the same valleys, and some of the old ridges have undergone emergence since they were built. Two bays were studied in detail; these are Auburn Cove and Etienne Bay (fig. 122). The datum for the altitudes given is the "seaweed line," approximately mean low tide; the altitudes were determined by hand leveling.

407-856 0-71-7 

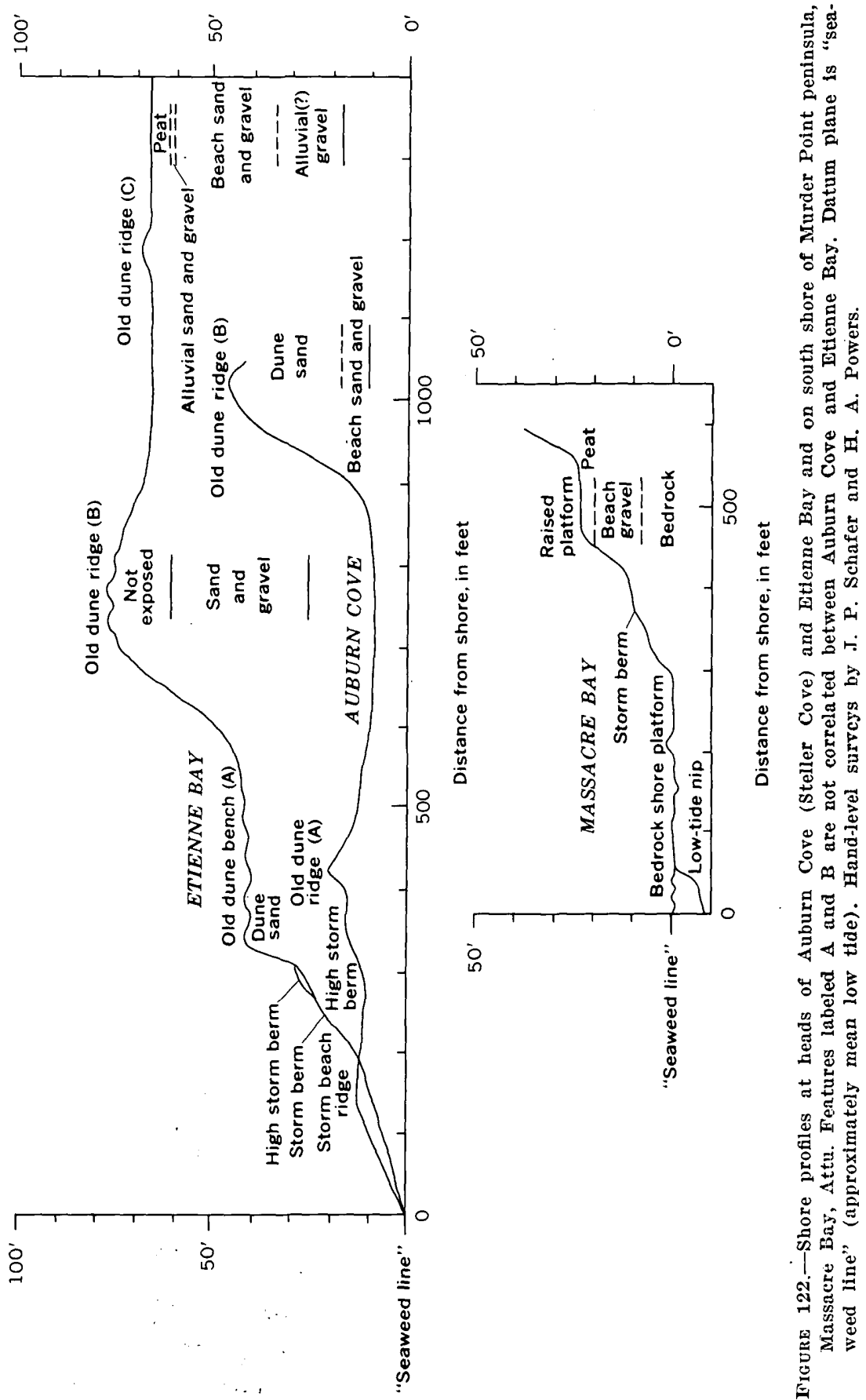
Near the middle of the head of Auburn Cove, the beach rises to a storm-beach ridge at an altitude of about 13 feet. This ridge is composed of sand and gravel and has a thin mantle of dune sand. Vegetation is almost absent seaward from the crest of the ridge, but inland from the crest there is patchy growth probably developed since the previous winter's storms. About 200 feet inland is a 15 -foot berm covered by continuous vegetation that has not developed an underlying peaty layer. Comparable berms near Massacre Bay, such as the storm berm in the Murder Point profile (fig. 122), contain military debris which could not have been incorporated before 1943. Therefore, this berm is believed to have been built by exceptionally severe storms within about the previous decade, and is called a high storm berm. Inland from the berm is the 20 -foot-high dune ridge $A$, which is covered by dense turf underlain by a peaty layer and is not now within reach of marine activity. Next inland across a broad swale is dune ridge $\mathrm{B}$, which reaches an altitude of about 45 feet. An exposure cut by East Fork Steller River shows that this ridge is composed of dune sand overlying beach sand and gravel, and the top of the beach deposit is at an altitude of about 17 feet. As modern stormbeach deposits extend to altitudes of well above 20 feet on Attu, ridge $B$ could have been built at a time when sea level was no higher than at present. Ridge $B$ is the first of a group of ridges that extends about a quarter of a mile farther inland; there are at least seven other ridges, all slightly lower than ridge $B$. More than a mile inland from the present beach is a remnant of a group of old ridges lying in the alluvial plain in front of the end of the ridge between East and West Steller valleys; the altitudes of these ridges were not measured.

At the head of Etienne Bay are a storm berm and a high storm berm that are comparable in amount of vegetative cover to the storm ridge and berm at Auburn Cove but are somewhat higher. The high storm berm is absent from the middle part of the head of the bay; at the mouth of the outlet stream from Etienne Lake the berm is continuous with a stream terrace. Behind the storm berms, a cliff about 12 feet high exposes crossbedded dune sand. Above this cliff is the 40-foot-high bench $\mathrm{A}$, about 250 feet wide, which has knobby dune topography and a cover of dense turf underlain by peat. Behind bench $A$, an old scarp rises to dune ridge $B$, which is about $65-90$ feet in altitude, highest in the middle of the valley, and has very knobby dune topography. An exposure cut by the outlet stream from Etienne Lake shows that between the altitudes of 25 and 60 feet ridge $\mathrm{B}$ is composed of interbedded sand and gravel that dips very gently seaward; the material above 60 feet is not exposed but is probably mostly dune sand. It is not certain whether the 35-foot thickness of 
sand and gravel is a beach deposit or is an alluvium deposited behind a beach ridge. Regardless, the deposit was formed at a time of submergence to a depth probably 30 or more feet below present sea level; the highest present storm-beach deposits seen on Attu are at altitudes of less than 30 feet.

Inland from dune ridge $\mathrm{B}$ at Etienne Bay, the plain that extends to Etienne Lake has an altitude of about 65 feet on its seaward part. The plain is crossed by at least seven low dune ridges concave seaward; the westernmost is shown on the profile (fig. 122) as old dune ridge C. These ridges evidently mark successive positions of the beach as it prograded. On the plain at the west side of Etienne Lake are two dune ridges concave toward the lake. The sediment load of the streams entering the lake is trapped by the lake, so that alluvium is contributed to the plain only from short steep gullies on the valley walls. An exposure cut in the plain by the outlet stream from Etienne Lake about 1,300 feet inland from its mouth shows the following section:

Thickness (feet)

Turf and peat.--_---

Sand and gravel, horizontally bedded, probably alluvial__............ 1

Sand and gravel, dipping about $5^{\circ}$ seaward, probably a beach deposit_-_---- 26

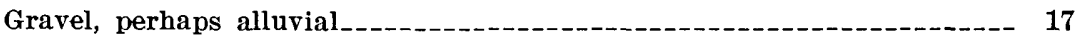

$481 / 2$

A sample from the basal 6 inches of the peat at the top of this section has been given a radiocarbon age of $1,750 \pm 100$ years (Kulp and others, 1951, p. 568). This gives a minimum age of the construction of this part of the plain, previous to a local 30 -foot emergence.

Auburn Cove and Etienne Bay show that all Attu bays have not had the same history. Other bays also show different profiles. For instance, at Earle Cove a 23- to 26-foot-high abandoned berm, covered by turf and peat, lies behind the 13- to 16-foot-high modern storm berm. The scarp cut in this deposit by storm waves exposed a driftwood log, a sample from which has been given a radiocarbon age of $650 \pm 150$ years (Kulp and others, 1952, p. 412). This must be older than the last slight emergence here.

Beaches smaller than those of the large bays of Attu are scattered along the Near Islands shorelines. Old abandoned beach ridges comparable to those of the large bays occur at the mouths of some small valleys, as at the heads of Armeria Bay and McDonald Cove, Agattu. Alexai Point, Attu, is tied to the mainland by a tombolo about 1 mile long. In front of many sea cliffs, especially the inactive ones, lie narrow beaches commonly with storm ridges or berms. Each beach segment is bounded by rocky points at either end, and the size of 
beach material and the angle of slope of the beach are much affected by the kind of bedrock within these bounds, as well as by degree of exposure to wave action. These beaches are generally more stony than the large bayhead beaches. In some short beaches, such as one on Patricia Bight, Agattu, fragments of green sea urchin spines compose more than a quarter of the material. Narrow beaches lie in front of the colluvial benches at the bases of some inactive sea cliffs, and beach material may in part underlie the benches.

\section{CHANGES OF ALTITUDE}

It was concluded in a previous section that not all parts of the Near Islands had the same history of preglacial changes of altitude. The shoreline deposits, previously discussed, and the raised erosional platforms of Attu show that this conclusion may be extended to postglacial time as well. The large number of small postglacial faults on Attu must have produced differential movement of parts of the shoreline. Present shore platforms have been vertically dislocated by recent faults near Earle Cove and near Alexai Point, Attu; these platforms are crossed by fault scarplets as much as 3 feet high.

The broadest and highest raised postglacial platform of Attu is on the headland east of Earle Cove. It is about half a mile wide and $21 / 2$ miles long and reaches an altitude of nearly 100 feet. Its surface, which is now covered with vegetation, bears scattered beach ridges and groups of stacks, and the old cliff to the south resembles the inactive cliffs along the present shoreline. On the terrace are two recent fault scarplets, each trending slightly north of west and upthrown to the north. The emergence of this singular platform is certainly the result of local crustal movement. An impressive group of closely spaced parallel beach ridges, the inland members of which reach nearly 100 feet in altitude, lies just east of this raised platform, and may have emerged at the same time as the platform.

The raised platforms seen elsewhere on Attu, principally around Massacre Bay and the islands off Chicagof Harbor, are much narrower and lower than the Earle Cove raised platform. One near Murder Point (fig. 122) is about 100 feet wide, and its bedrock surface, as shown in a gravel pit exposure, is at an altitude of about 7-10 feet; it is overlain by beach gravel about 11 feet thick, which is covered by dense turf and peat.

Inactive cliffs are sufficiently widespread to indicate a general post-. glacial change of level in the Near Islands. The slight emergence which they record may have resulted from eustatic, isostatic, or diastrophic movement, or any combination of them. However, the oc- 
currence of a recent glacial eustatic emergence of about 5-6 feet has been widely inferred (Stearns, 1941; Fairbridge, 1950, p. 350), and such an emergence might well account for the prevalence in the Near Islands of inactive cliffs and of slightly prograded beaches at their bases. The evidence in the Near Islands indicates a general emergence of about 5-10 feet.

\section{WIND ACTION}

Dune sand has accumulated behind beaches along the Near Islands shorelines where there is sand on the beach and space between beach and cliff ; and, of course, the broader and sandier the beach, the larger the dunes. The largest dune masses are on the modern and ancient beach ridges at the heads of the bays of Attu, previously described. Among the small masses are the eolian parts of colluvial benches in front of inactive sea cliffs. On sparsely vegetated modern storm-beach ridges and berms, such as the 13-foot-high ridge at Auburn Cove and the 20-foot-high berm at Etienne Bay (fig. 122), there is little dune sand because there is little to protect it from storm-wave erosion. Some sand is blown inland onto turf-covered surfaces beyond the reach of present wave action and is fixed in position as soon as it falls into the dense low vegetation. Sand accretion on turf results in an unstratified deposit after organic material had been leached out. In some places, such as the modern storm-wave scarp cut in the 40-foot-high dune bench A at Etienne Bay (fig. 122), dune sand shows typical eolian, crossbedding and must therefore have been deposited on a surface nearly bare of vegetation. It is unlikely that any reasonable change in Aleutian climate would result in greater sand mobility and less plant cover. Instead, sand supply may have been increased by beach widening, such as would be caused by a slight drop of sea level (cf. Judson, 1946, p. 383-384). The parabolic dunes (concave seaward) on the crest of the 65 - to 90 -foot-high dune ridge $\mathrm{B}$ at Etienne Bay may hàve been formed under similar conditions at an earlier time.

On the north coast of Shemya, the 200-foot-high sea cliff is capped by eolian silt and sand, locally 15 feet or more thick. This deposit extends 200-600 feet from the crest of the cliff and is thinner inland; it has undulating bedding, and it contains scattered granules and pebbles up to three-fourths inch in diameter. It is composed of material blown up from the beach and the cliff by strong onshore winds. Members of a 1949 field party reported that they observed such particles being blown up bver the crest of the cliff. $\mathrm{A}$ belt of dunes extends 500-2,500 feet inland from the low south shore of Shemya and covers the low western peninsula, probably as a result 
of abundant sand supply on the adjoining beaches. Aside from such deposits, which are related to coastal sources of material, there is very little evidence of inland wind action in the Near Islands, not because of lack of wind but because of the inhibiting effects of dense vegetation and of the general moistness of exposed fine-grained material. A little wind erosion occurs on bare frost-disturbed ground, especially at high altitudes, where there is more such bare ground.

\section{FROST ACTION}

The present climate of the Near Islands, as described in the first section of this report, is distinctly maritime, with cool summers and moderate winters. The depth of frost penetration is probably no more than a few feet, at least at lower altitudes, and there are probably many cycles of shallow freeze and thaw in a year. Extrapolation, based on a likely adiabatic lapse rate, of the mean annual temperature upward from sea level indicates that the freezing isotherm lies near or above an altitude of about 1,600 feet. Perennially frozen ground can be present only above that level. However, the relatively uniform distribution of precipitation through the year, the low evaporation rate, and the abundance of moisture-retaining vegetation and peat combine to maintain a high moisture content in the ground, even without a perennially frozen substratum, and this is conducive to strong frost action.

\section{FROST-BREAKING OF ROCK}

Frost-breaking is by far the most important agent of rock weathering in the Near Islands, and, as discussed previously, it is especially effective in the development of the shore platforms. The surface rind of some rocks, especially mafic igneous rocks, has been affected by oxidation and other chemical weathering processes. Some rocks, especially massive tuffs, cropping out along shorelines show crumbling and honeycomb weathering, possibly resulting from crystallization of salt; some jointed tuffs have developed concentric exfoliation shells in small joint blocks; and shallow chemicalweathering profiles occur in surficial material in some places. However, almost all the surficial mantle consists of angular frost-broken fragments little modified by chemical weathering.

The ubiquitous mantle of frost-broken material shows a wide range of particle sizes and shapes in areas of different bedrock types. The closely jointed siliceous sedimentary rocks of Agattu disintegrate rapidly into small angular blocks and chips. Sparsely jointed igneous rocks such as the Tertiary diabase on Agattu produce conspicuous 
accumulations of large boulders. In some places the mantle includes much fine material, probably mostly of sand and silt sizes, and little clay. The smallest particles visible with a hand lens are angular, and frost breaking is probably responsible for reduction of material to silt size (cf. Dylik and Klatka, 1952; Hopkins, 1949, p. 121). Frost action shatters stones near the surface in gravel or glacial till and loosens compact till.

Disintegration and removal of debris generally produce craggy, uneven summits and slopes on sparsely jointed rocks, and smooth summits and slopes on closely jointed rocks. Disintegration is particularly rapid on glacially steepened slopes where debris is rapidly removed. Many summer snowbanks in the mountains lie in shallow basins, in bedrock or in mantle, that may be nivation depressions.

The thickness of frost-broken material is greater where the rock is relatively easily shattered and where the debris is removed only slowly. On flat or gently sloping hilltops, the accumulated material at least partly protects bedrock from further frost action; in the few vertical exposures seen the debris was less than 3 feet thick. On some flat hilltops of the Agattu plateau, the outcrop of faulted, tilted sedimentary rocks is reflected in the thin mantle of debris on the bedrock. Debris must be much thicker on the lower parts of some slopes; several exposures 6 feet deep did not show the full thicknesses.

\section{MASS MOVEMENT OF FROST-BROKEN MATERIAL}

The most important process in postglacial slope sculpture is movement of the mantle of frost-broken material under the influence of frost action. Much of the surface has microrelief features produced by frost-induced movement of the mantle. At no place were streams or rainwash seen to be dissecting such microrelief forms, and, as is mentioned in the discussion of postglacial stream action, there is very little evidence of erosion by surface runoff in the broad interfluvial areas, where masswasting is dominant.

Several more or less interdependent factors apparently affect the movement of frost-broken material in the Near Islands: (a) angle of slope; (b) amount of soil moisture; (c) kind of plant cover; (d) size of fragments; (e) altitude. Where slope angle, amount of soil moisture, extent of plant cover, and fragment size are all moderate, the debris generally forms turf-banked terraces, which are discussed in a separate section.

No measurements have been made of rate of movement of debris, but the appearance of slopes suggests that it probably is slow, of the 
order of an inch to a foot in a year. The mantle of debris is structureless to crudely stratified to finely laminated. On the hillside at the northeast corner of Karab Cove, a roadcut shows that frost-broken rock has crept at least 100 feet downslope on top of glacial till. Obscure furrows extend directly down some slopes. No indication of rapid flow of saturated material as mudflows was seen.

$<$ On cliffs in the mountains and on the coasts, small masses and single fragments of frost-loosened rock fall and roll down and accumulate as taluses. Large masses descend as rockfalls and rockslides, coming to rest as hummocky bouldery debris. A rockslide mass blocks the mouth of a small valley on the north side of Etienne Bay 11/2 miles northeast of Etienne Head; the cliff cut in this mass by wave action exposes unsorted material consisting of many large angular blocks in a coarse matrix. Rock glaciers in some of the cirques and upper valleys on Attu are probably derived from taluses or rockfall masses.

Taluses show great differences in degree of weathering and extent of vegetation. Most of those on Agattu and at lower altitudes on Attu (including those of sea cliffs) are sparsely to heavily covered with vegetation except for small areas at their apices, whereas taluses high in the mountains of Attu are bare of vegetation and are fresh in appearance. Taluses that are covered with vegetation apparently have a very slow rate of addition of material, and it is not known whether they have been built at the present rate within postglacial time or whether they were constructed in part by stronger frost action during glacial time.

Many slopes at middle and high altitudes are thinly and smoothly covered with frost-broken debris (fig. 123, upper right). Such slopes are generally vegetated and are steeper than adjacent slopes that bear turf-banked terraces. Bedrock outcrops are common on some of these slopes. Many gentle to moderately steep slopes at low altitudes are smoothly covered by turf and peat that are thick enough to inhibit the formation of turf-banked terraces and in places probably thick enough to completely protect the underlying debris from frost action. Debris apparently moves by creep. or solifluction even below the depth affected by frost action, because of the generally large amount of moisture and abundant fine-grained material.

\section{TURF-BANKED TERRACES AND STONE STRIPES}

Turf-banked terraces (fig. 123) are the principal microrelief features of the mantle of frost-broken rock on slopes. A terrace consists of a relatively gently sloping tread of bare or sparsely 


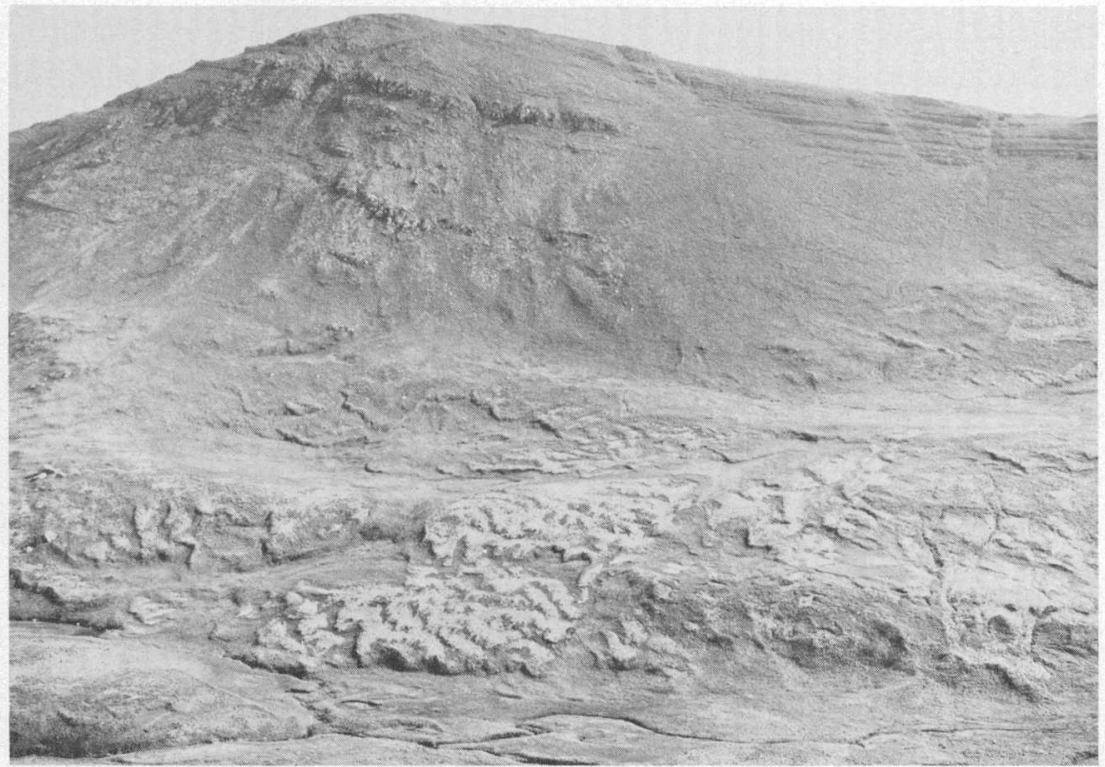

Figure 123.- Turf-banked terraces on lower slope of Peak 5, Agattu, viewed from southwest. Many of the terraces extend obliquely downslope. The slope at upper right is more smoothly covered with debris. Relief in area of photograph is about 1,000 feet.

vegetated rock debris and a more steeply sloping bank covered by dense turf and peat. The most abundant plants of the turf are crowberry (Empetrum), grasses, sedges, mosses, and lichens; less abundant are dwarf willows (Salix), a dwarf rhodedendron, clubmosses (Lycopodium), cloudberry (Rubus), and others (Collins and others, 1945). Turf-banked terraces on Agattu are very well developed, and the following discussion refers to them unless otherwise specified.

Most turf-banked terraces are between altitudes of about 300 and 1,300 feet and are on slopes that range from about $10^{\circ}$ to $35^{\circ}$. The common ranges of terrace measurements are tread width, 5 to 25 feet; tread length along the contour, 10 to 50 feet or more (generally at least several times longer than wide) ; tread slope outward, $3^{\circ}$ to $20^{\circ}$; bank height, 6 inches to 5 feet; bank slope outward, $25^{\circ}$ to $75^{\circ}$. The steeper the angle of the slope as a whole, the steeper are the tread and bank slopes. Many terraces are strongly lobate downhill. Some flights of terraces strongly resemble in form those of hot springs.

On gentle slopes, terraces extend nearly horizontally along the contour, but on steeper slopes they generally extend obliquely downslope (fig. 123). On the steepest slopes on which terraces are well developed, the inclination of terraces (measured in the plane of the slope) 
locally reaches $75^{\circ}$. At no place, however, were such terraces seen to grade into vegetation stripes trending directly downslope (cf. Sigafoos, 1951, p. 289, 295).

Nearly every hilltop on the Agattu plateau is crowned by what is essentially a large turf-banked terrace. Such hilltop terrace has a gently convex surface (commonly bearing small slope terraces) and a prominent turf bank that nearly or quite surrounds it. The lobate bank is the margin of the debris mass that has spread outward from the exposed hilltop and has encroached on lower slopes covered with denser vegetation. Hilltop debris masses have spread outward from bedrock outcrops, and some terraces have rock monuments at their centers.

At low altitudes, down to 100 feet above sea level, where vegetation is denser than at higher altitudes and readily encroaches on bare areas, turf-banked terraces are sparsely distributed as isolated bare treads, rimmed by banks. At high altitudes the slopes on which terraces are formed are gentler than at the middle altitudes, roughly from 300 to 1,100 feet, in which terraces are most extensive; vegetation is less dense and frost action is stronger. The most abundant mat-forming plants are dwarf willows, mosses, and lichens. Terraces are smaller in all dimensions, and the treads and banks are less steep. On some slopes which have too sparse vegetation and are too steep for well-formed terraces, there are isolated terraces consisting of low turf banks supporting small treads. Terraces are absent from the steep slopes of rugged peaks, but they occur at altitudes near 2,500 feet on the rounded summits on Attu.

Turf-banked terraces are less well developed on parts of Attu than on Agattu, perhaps because not so many of the rocks on Attu are as closely jointed and bedded as those of Agattu and thus do not break up as readily into small fragments. Terraces are absent from Shemya, for slopes on the plateau are too gentle to develop terraces at such low altitudes, and the slopes of the sea cliffs are too steep.

The form of turf-banked terraces shows clearly that the turf bank retards the downslope mass movement of the rock debris. According to Antevs (1932, p. 61), terraces are formed when "very slow, viscous flow of debris is checked by dense, tough turf." Probably part of the movement is creep caused by frost heaving, and part is viscous flow in saturated material (Sigafoos and Hopkins, 1952, p. 178-181). When ground ice thaws in the spring, surface materials become very mobile. In the Near Islands the material on the treads of many turfbanked terraces is wet and unstable even in July and August.

Isolated terraces form at low altitudes in the Near Islands wherever disruption of turf produces a frost scar; the material thus 
laid bare is more mobile, and its downslope movement pushes up a bank of turf (cf. Hopkins and Sigafoos, 1951, p. 66-70). Isolated terraces form at high altitudes in areas of sparse vegetation wherever a mat of plants becomes large and well anchored by roots and retards the downslope movement of the looser material from upslope. At intermediate altitudes, where terraces are most extensive, the interaction of mass movement and vegetation over a period of time produces essentially an equilibrium condition of terraces of subequal size and spacing. The available data do not show how long a terrace maintains its identity, or how far down a slope it may move, or how fast it moves. Some forms seen in the field appear to be old terraces being stabilized by vegetation and new terraces developing from frost scars. These two processes are probably approximately in balance on a slope such as that shown in the lower part of figure 123.

On Agattu, stone stripes similar to those discussed by Sharp (1942) occur at moderate altitudes on bare, relatively fine-grained debris. They are generally on slopes of $4^{\circ}$ to $10^{\circ}$ and rarely as much as $24^{\circ}$. Such situations are almost entirely on the treads of turf-banked terraces. Stone stripes are best developed in debris that is mostly finer than $1 \mathrm{inch}$. The stripes of stones and the intervening stripes of finer material are subequal in width, ranging at different places from 2 to 7 inches. The stone stripes are composed mostly of fragments between $1 / 4$ and 4 inches, with little finer interstitial material. The intervening earthy stripes consist mostly of particles less than one-fourth inch, with much material of sand and silt sizes. The stone stripes are somewhat less deep than they are wide, and their stones have been segregated out of the underlying and adjacent poorly sorted material.

Stone stripes everywhere extend exactly downslope and are curved smoothly around irregularities and obstructions. Where constrictions occur, stone stripes converge and join. Slopes mantled by debris that contains but a small proportion of fine particles show lineation of stones or crude striping in places, but not the regular sorting of well-developed stripes. Stripes fade out where slopes become too steep for their development; at different places the maximum angle of slope on which they occur is $6^{\circ}$ or more. On steeper slopes, there is downslope lineation of rock fragments or crude striping in places.

Stone stripes are very rarely found on slopes of less than $4^{\circ}$. Nearly horizontal treads occur in many places, particularly in the central parts of large hilltop terraces, but very little sorting of debris has occurred on them. Platy fragments commonly stand on edge, but without a distinct pattern. Stone nets $1-3$ feet in diameter 
and stone garlands were seen on a few terrace treads and on a few lake-shore flats.

\section{FROST-PRODUCED PONDS AND TUSSOCKS}

Besides the ponds of clearly glacial or marine origin in the Near Islands, there are many that appear to have been produced by local. radial ice thrust: These do not lie along distinct water courses, but in poorly drained, flat or gently sloping areas, and are characterized by low rims of turf raised above the surrounding areas. On slopes the rim is poorly developed or absent on the uphill side of the pond. Few such ponds are present above an altitude of 1,000 feet, and almost none occur above 1,500 feet. The bottoms are composed of peat, frost-broken debris, or other surficial deposits.

Most rimmed ponds in the areas studied are within the following limits: They are on flat areas or on slopes of less than $10^{\circ}$; their diameters range from 3 to 35 feet; on flat areas their rims are less than 2 feet and generally about 1 foot above the surrounding surface; the water in the ponds is $1 / 2$ to $11 / 2$ feet deep near the margins and is generally no more than 3 feet deep in the centers of the larger ponds. On flat areas, water levels in rimmed ponds are generally within 1 foot above or below the level of the surrounding surface beyond the rim. (A few small ponds on flat valley floors have rims as high as 4 feet, water levels as much as 3 feet above the surrounding surface, and depths of more than 6 feet; and a few other such ponds lack raised rims. Low rims are composed of turf and peat, but the good water retentiveness of some large rims suggests they have silt cores. Outflow from most ponds is by seepage through the rims, not by surface outlets.

Field observations show a nearly continuous series of ponds, from small frost scars to well-developed rimmed ponds, and this is believed to be a genetic sequence. On better drained, generally steeper slopes, frost scars develop into turf-banked terraces. On poorly drained flat areas or gentle slopes, a rim can be raised around a frost scar by differential freezing and frost thrusting (cf. Hopkins and Sigafoos, 1951 , p. 76-84). The freezing isotherm is deeper beneath a frost scar than beneath the surrounding turf, and, as frost thrusting is normal to the isotherm, the slope of the isotherm results in a lateral component of pressure.

An incipient rim encloses a shallow basin that can contain standing water at least part of the time, and from which some fine-grained material, organic and inorganic, may be decanted at times of overflow. However, large well-formed rims are believed to be due to 
thrusting by pond ice as a result of temperature changes. Rims are generally absent from the uphill sides of ponds on slopes because thrusting stress is more easily relieved by movement on the other sides. Small breaks in rims are healed by plant growth. The term "thrust ponds" (Ives, 1941, p. 290-295) may be used for rimmed ponds in the Near Islands, although Ives's suggestion that deer caused the original depressions is inapplicable here.

Advanced stages of development of thrust ponds are marked by decrease in depth of water due to deposition of fine-grained sediment containing much organic matter. Basin floors are invaded by plants, commonly pure stands of one of several aquatic plants. No basin with a breached rim was seen; lowering of water level results from drainage through or under turf and peat. A few recently drained basins had funnel-shaped holes in the peat of their floors and were apparently drained rapidly by the opening of tumnels in the peat. No turf-covered abandoned basins were seen; once they are drained, their faint topographic expression probably disappears rapidly.

The thrust ponds and drained thrust-pond basins of the Near Islands superficially resemble the features described by Hopkins (1949) as thaw lakes and thaw sinks. However, thaw lakes and sinks lack raised rims and are formed by differential thawing and subsidence of perennially frozen ground.

Another common type of pond is represented by the chains of small pools up to 2 feet wide that are separated from each other by densely vegetated bars along channels. The bars seem to result from the accentuation of small channel irregularities by plant growth, commonly with the development of a plunge pool below each bar, comparable to the "staircase ponds" of Ives (1941, p. 287-290).

In some places at low altitudes, an unidentified coarse grass produces tussocks that are as much as 2 feet high, are closely spaced and very dense and tough, and are locally arranged approximately in lines down gentle or moderate slopes. Smaller tussocks are common where mosses are the most abundant plants. No observations on tussock origin were made in the Near Islands, but formation of some tussocks has been attributed to differential frost heaving (Sigafoos and Hopkins, 1951).

In coastal areas of the Near Islands, conspicuous isolated tussocks or dense clumps of luxuriantly growing plants are apparently caused by manuring by birds and foxes. Along some fox trails are clumps about 1 foot high, commonly growing around boulders; fox droppings were found on some of these. Isolated rock monuments and boulders on some hilltops and ridges have been used as perches by birds, as is shown by abundant bird droppings; around these 
perches, grasses and other plants grow luxuriantly. Such bird perches have been noted elsewhere in the Aleutians (Collins and others, 1945, p. 69 ; Kellogg and Nygard, 1951, fig. 16; Thompson, 1951).

\section{EARLY POSTGLAGIAL FROST ACTION}

During the disappearance of the large Wisconsinan glaciers, the climate of the Near Islands must have been more rigorous than that of the present. The best physical evidence of late-glacial or early postglacial climate was found in an excavation near the north end of the airfield at Massacre Bay, Attu. The materials exposed are: Thickness
(feet)

Turf and brownish-black peat.---_--.-- 1

Sand and silt, pebbly, crudely stratified ; frost-moved material_-_-_-_-_-- 1

Glacial till, yellowish-brown, silty, with yellow sandy masses_._._-_._-.- $\quad 31 \frac{1}{2}$

Bedrock, purplish-gray, very fine grained, soft, with two black carbona-

ceous layers; probably an altered volcanic rock

$91 / 2$

Several wedge-shaped masses of till extend 1 to $31 / 2$ feet downward in the bedrock. The wedges are 1 inch to 2 feet wide, and they extend several feet horizontally at different angles to the face of the exposure. The deformation of the carbonaceous layers in the bedrock shows that the fissures now filled by till were opened forcefully, with the exertion of sideward pressure.

The wedge structures were formed probably by ice wedges in perennially frozen ground and filled by slumping from above when the ground thawed (cf. Taber, 1943, p. 1510-1527 and illus.; Schafer, 1949, p. 165-171). The wedge structures extend about 2 feet upward in the till above the bedrock. Therefore, at the time of the ice wedges the annually frozen-and-thawed surface layer was about 2 to $21 / 2$ feet thick. Perennially frozen ground exists only where the mean annual temperature is at or below $32^{\circ} \mathrm{F}$ (Taber, 1943, p. 1506). As the mean annual temperature at Massacre Bay is now about $38^{\circ} \mathrm{F}$ (based on 22 months' record), this indicates a rise of at least $6^{\circ} \mathrm{F}$ since the time of formation of the ice wedges. The nearest area where perennially frozen ground now occurs in Alaska is near the head of Bristol Bay, more than 1,200 miles east-northeast of the Near Islands (Hopkins and others, 1955, fig. 5).

Other features possibly indicating stronger frost action in the recent past are the involutions in surficial deposits at the east quarry on Shemya. A layer of pebbly, silty sand, originally 1-2 feet thick, has been strongly deformed, and tongues of it thrust downward into well-bedded sand. These tongues are nearly equidimensional in plan. They are most likely involutions produced by differential frost 
heaving in ground rendered unstable by the growth and thawing of ground ice masses. They are not now forming here, for the 3-foot cover of turf and peat, which evidently protects the sand from strong frost action, is not affected by the deformation. The involutions are older than the peat layer, and although the modern climate might produce involutions on bare ground, this area presumably has not been bare since early postglacial time. A similar conclusion might be reached about the age of conspicuous frost shattering of stones in gravel beneath several feet of peat in the west quarry on Shemya.

Large taluses that are mostly covered with vegetation may have been constructed during a time of stronger frost action, as previously mentioned. Any other surface frost features formed at a time of different climate have been effaced by modern frost action.

\section{SUMMARY OF GEOLOGIC HISTORY OF THE NEAR ISLANDS}

The oldest rocks of the Near Islands are a thick heterogeneous sequence of chert, argillite, graywacke, conglomerate, tuff, tuff breccia, and pillow lavas deposited in a tectonically and volcanically active marine environment and on surfaces of considerable topographic relief, probably with local islands during late Mesozoic or early Tertiary time. The absence of potash feldspar, schist, or gneiss in the detrital material, together with the low content of quartz grains, suggests that the area was not receiving detritus from a continental terrain. Intrusion of albite granite and diabase or gabbro may have accompanied or closely followed the volcanism and may have been responsible in part for the spilitic character of many of the volcanic country rocks. This heterogeneous sequence now forms the basement rocks on Attu and Agattu and the Krugloi Formation on Agattu.

Uplift accompanied by deformation then led to subaerial erosion of the basement rocks of Attu; and the detritus was deposited as marine gravels and graywacke which rest unconformably on the basement rocks and constitute the Nevidiskov Formation of southwestern Attu. During Miocene(?) time, quiet marine sedimentation in a slightly euxenic basin followed without interruption and formed the well-banded and bedded argillite, chert, limestone, and pebble conglomerate beds of the Chuniksak Formation. At about the same time gravel, carbonaceous sandstone, and siltstone were apparently being deposited along shores and in lagoons to form the Chirikof Formation of eastern Attu.

Gabbro and diabase of tholeiitic type then intruded the basement rocks of Attu and Agattu-the Krugloi, Nevidiskov, and Chuniksak 
Formations-to form many dikes, sills, and small irregular plutons. Intrusion of albite granite and keratophyric dikes probably accompanied the gabbro and diabase. During middle Tertiary time extensive faulting, both normal and strike slip, formed a reticular pattern with predominantly east, northeast, and northwest trends, and broke the rocks into numerous fault blocks. Uplift accompanied this faulting, and, with the exception of the basement rocks of Shemya, the younger deposits that are now to be seen were subaerial.

Stream gravels, volcanic mudflows, and hornblende-bearing lava flows were deposited on the subaerial erosion surface after the middle Tertiary uplift to become the Massacre Bay Formation of eastern Attu, and possibly during or near this time the hornblende andesite and dacite dikes of Chirikof Point were intruded. Near this time also the muds and silts that became the basement rocks of Shemya were being deposited in a marine environment. Later the andesitic, and basaltic tuffs of Shemya were erupted, in part at least under water or ice, and were intruded by the small plugs of basalt porphyry. At some indefinite time, probably late Tertiary, volcanic activity occurred at the site of the present eastern tip of Agattu Island, leaving a radiating system of dacite porphyry. Just before the glacial period, the red conglomerates and sands of the Faneto Formation were deposited by streams in central Attu. Throughout the late Tertiary, normal and strike-slip faulting continued in the area, displacing the beds and strandlines.

Prominent effects of glaciation of Wisconsinan Age are found in the Near Islands, and evidence of whatever earlier glacial advances that may have occurred has been obscured or destroyed. The Wisconsinan glaciers eroded deep troughs in the mountainous highlands of Attu and Agattu, and spread out onto the submarine shelf surrounding the islands. Most of the ice-transported debris was apparently deposited on the shelf, now submerged, and outwash trains from recessional glacier stages partly filled some of the Attu valleys. Postglacial stream erosion and deposition and wind action have been slight in most places, and most of the postglacial weathering of bedrock and movement of debris on slopes has been accomplished by frost action. A marine bench cut in bedrock along many parts of the present shorelines, and backed by inactive sea cliffs, suggests a general postglacial lowering of sea level of about 5-10 feet, but differential postglacial uplift of some parts of Attu is demonstrated by raised beaches and erosional benches at different altitudes in different places. Fault scarplets cutting the turf mantle of Attu show that faulting and deformation is still continuing. 


\section{REFERENCES CITED}

Allen, V. T., and Scheid, V. E., 1946, Nontronite in the Columbia River region: Am. Mineralogist, v. 31, nos. 5-6, p. 294-312.

Antevs, E. V., 1932, Alpine zone of Mount Washington Range: Auburn, Maine, Merrill and Webber Co., $118 \mathrm{p}$.

Bartrum, J. A., 1916, High level rock platforms-a phase of shoreline erosion: New Zealand Inst. Trans., v. 48, p. 132-134. 1926, "Abnormal" shore platforms: Jour. Geology, v. 34, p. 793-806.

Bradley, W. C., 1958, Origin of marine-terrace deposits in the Santa Cruz area, California : Geol. Soc. America Bull., v. 68, p. 421-444.

Bramlette, M. N., 1946, The Monterey formation of California and the origin of its siliceous rocks: U.S. Geol. Survey Prof. Paper 212, $57 \mathrm{p}$.

Capps, S. R., 1934, Notes on the geology of the Alaskan Peninsula and Aleutian Islands: U.S. Geol. Survey Bull. 857-D, p. 141-153.

Coats, R. R., 1952, Magmatic differentiation in Tertiary and Quaternary volcanic rocks from Adak and Kanaga Islands, Aleutian Islands, Alaska: Geol. Soc. America Bull., v. 63, no. 5, p. 485-514.

- 1956, Reconnaissance geology of some western Aleutian Islands: U.S. Geol. Survey Bull. 1028-E, p. 83-99.

Collins, H. B., Jr., Clark, A. H., and Walker, E. H., 1945, The Aleutian IslandsTheir people and natural history: Washington, Smithsonian Inst., War Background Studies 21, $131 \mathrm{p}$.

Cooper, W. S., 1942, Vegetation of the Prince William Sound region, Alaska, with a brief excursion into post-Pleistocene climatic history: Ecol. Monographs, .12; no. 1, p. 1-22.

Cotton, C. A Wileỹ \& 'Sons, $343 \mathrm{p}$.

1951, Seacliffs of Banks Peninsula and Wallington-some criteria for coastal classification: New Zealand Geographer, v. 7, p. 103-120.

1952, Geomorphology [6th ed.]: New York, John Wiley \& Sons, 505 p.

Dylik, Jan, and Klatka, Tadeusz, 1952, Recherches microscopiques sur la disintegration periglaciaire; Soc. Sci. et Lettres Lodz (Poland) Bull., Classe $3, \mathrm{v}, 3$, no. $4,12 \mathrm{p}$.

Edwards, A. 'B:, 1941, Storm-wave platforms: Jour. Geomorphology, v. 4, p. 223-236.

1951, Wave action in shore platform formation: Geol. Mag., v. 88, p. $41-49$.

Fairbridge, R. W., 1950, Recent and Pleistocene coral reefs of Australia : Jour. Geology, v. 58, p. 330-401.

Fenneman, N. M., 1902, Development of the profile of equilibrium of the subaqueous shore terrace: Jour. Geology, v. 10, p. 1-32.

Gates, Olcott, and Gibson, William, 1956, Interpretation of the configuration of the Aleutian Ridge: Geol. Soc. America Bull., v. 67, p. 127-146.

Hess, H. H., 1949, Chemical composition and optical properties of common clinopyroxenes, part I : Am. Mineralogist, v. 34, nos. 9-10, p. 621-666.

Hills, E. S., 1949, Shore platforms: Geol. Mag., v. 86, p. 137-152.

Hopkins, D. M., 1949, Thaw lakes and thaw sinks in the Imuruk Lake area, Seward Peninsula, Alaska : Jour. Geology, v. 57, no. 2, p. 119-131.

Hopkins, D. M., Karlstrom, T. N. V., and others, 1955, Permafrost and groundwater in Alaska: U.S. Geol. Survey Prof. Paper 264-F, p. 113-146. 
Hopkins, D. M., and Sigafoos, R. S., 1951, Frost action and vegetation patterns on Seward Peninsula, Alaska : U.S. Geol. Survey Bull. 974-C, p. 51-101.

Ives, R. L., 1941, Tundra ponds: Jour. Geomorphology, v. 4, no. 4, p. 285-296.

Johnson, D. W., 1919, Shore processes and shoreline development: New York, John Wiley \& Sons, $584 \mathrm{p}$.

Judson, S. S., Jr., 1946, Late-glacial and postglacial chronology on Adak: Jour. Geology, v. 54, no. 6, p. 376-385.

Jutson, J. T., 1939, Shore platforms near Sydney, New South Wales: Jour. Geomorphology, v. 2, p. 237-250.

Kellogg, C. E., and Nygard, I. J., 1951, Exploratory study of the principal soil groups of Alaska: U.S. Dept. Agriculture, Agr. Research Adm., Agr. Mon. 7, p. 1-138.

Kondo, Nobuo, 1931, Alkali-granite from Attu Island, Aleutians: Jour. Geol. Soc. Tokyo, v. 38, p. 662 (in Japanese).

Kuenen, P. H., 1953, Significant features of graded bedding: Am. Assoc. Petroleum Geologists Bull., v. 37, p. 1044-1066.

Kulp, J. L., Feely, H. W., and Tyron, L. E., 1951, Lamont natural radiocarbon measurements, part 1 : Science, v. 114, no. 2970, p. 565-568.

Kulp, J. L., Tyron, L. E., Eckelman, W. R., and Snell, W. A., 1952, Lamont natural radiocarbon measurements, part 2: Science, v. 116, no 3016 , p. 409-414.

McQueen, H. S., 1931, Insoluble residues as a guide in stratigraphic studies: Missouri Bur. Geology and Mines, Bienn. Rept. State Geologist [1929-30], p. 102-131.

Sandell, E. B., 1944, Colorimetric determination of traces of metals : New York, Interscience, p. 1-487.

Schafer, J. P., 1949, Some periglacial features in central Montana: Jour. Geology, v. 57, no. 2, p. 154-174.

Scruton, P. C., 1953, Marine geology of the Near Islands shelf, Alaska: La Jolla, California Univ., Scripps Institute of Oceanography, doctoral dissertation; U.S. Geol. Survey, open-file report, p. 1-200.

Shapiro, Leonard, and Brannock, W. W., 1952, Rapid analysis of silicate rocks: U.S. Geol. Survey Circ. 165, 17 p.

Sharp, R. P., 1942, Soil structures in the St. Elias Range, Yukon Territory: Jour. Geomorphology, v. 5, no. 4, p. 274-301.

1946, Note on the geology of Agattu, an Aleutian island [Alaska]: Jour. Geology, v. 54, no. 3, p. 193-199.

Sigafoos, R. S., 1951, Soil instability in tundra vegetation: Ohio Jour. Sci., v. 51, no. 6, p. 281-29s.

Sigafoos, R. S., and Hopkins, D. M., 1951, Frost-heaved tussocks in Massachusetts : Am. Jour. Sci., v. 249, no. 4, p. 312-317.

- 1952, Soil instability on slopes in regions of perennially-frozen ground, in Frost action in soils [Alaska]: Natl. Research Council, Highway Research Board, Spec. Rept. 2, p. 176-192.

Simons, F. S., and Mathewsion, D. E., 1955, Geology of Great Sitkin Island, Alaska: U.S. Geol. Survey Bull. 1028-B, p. 21-43.

Stearns, H. T., 1941, Shore benches on North Pacific Islands: Geol. Soc. America Bull., v. 52, no. 6, p. 773-780.

Taber, Stephen, 1943, Perennially frozen ground in Alaska; its origin and history: Geol. Soc. America Bull., v. 54, no. 10, p. 1433-1548.

Thompson, W. F., Jr., 1951, Resources of the Western Aleutians: Washington Univ. (Seattle) unpub. M.A. thesis. 
Tröger, W. E., 1952, Tabellen zur optischen Bestimmung der gesteinsbildenden Minerale : Stuttgart, E. Schweizerbart. Verlag., p. 1-147.

Turner, F. J., and Verhoogen, Jean, 1951, Igneous and metamorphic petrology, 1st ed. : New York, McGraw-Hill Book Co., 602 p.

U.S. Army Air Force, 1945, Climate, weather behavior and topography of selected Alaskan and Aleutian stations: Weather Central, Alaska, 11th Weather Squadron, $103 \mathrm{p}$.

Wentworth, C. K., 1938, Marine bench-forming processes ; water-level weathering: Jour. Geomorphology, v. 1, p. 6-32.

Wentworth, C. K., and Palmer, H. S., 1925, Eustatic bench of islands of the North Pacific: Geol. Soc. America Bull., v. 36, no. 3, p. 521-544.

Wilcox, Ray E., 1959, Igneous rocks of the Near Islands, Aleutian Islands, Alaska: Internat. Geol. Cong., 20th, Mexico 1956 [Trabajos], sec. 11-A, p. 365-378. 


\section{INDEX}

[Italic page numbers indicate major references]

\section{A}

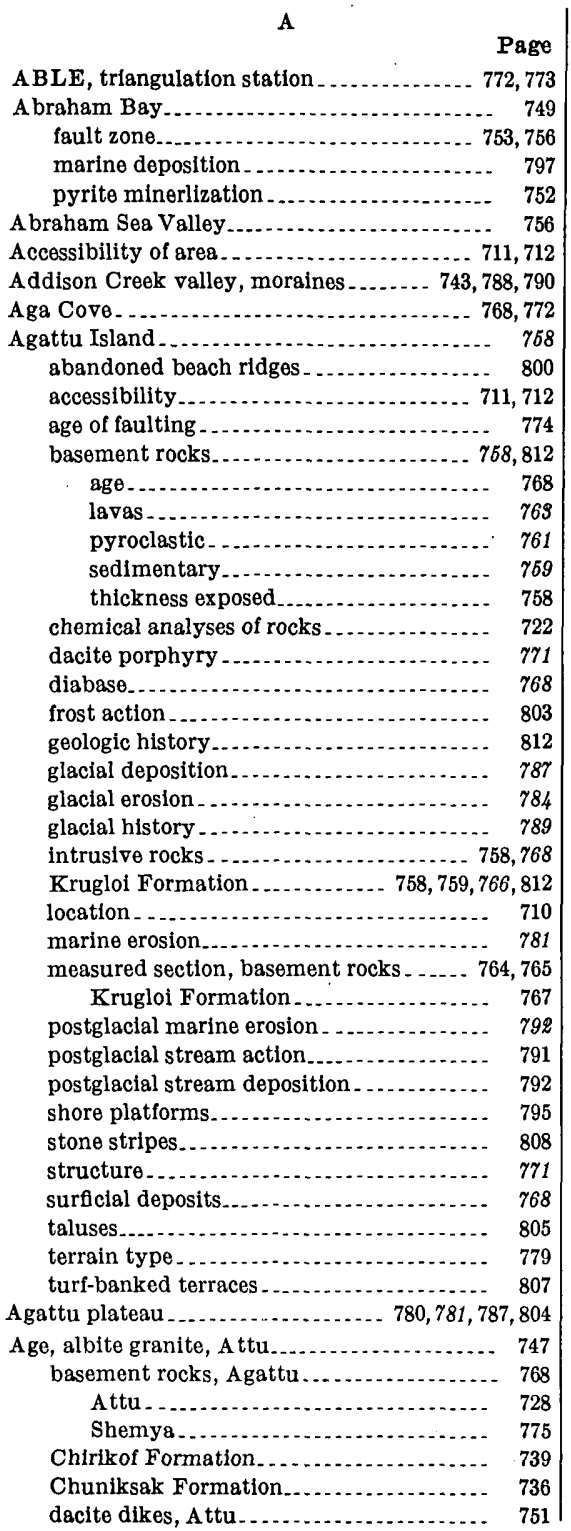

Age-Continued Page diabase, Attu.............................. 746

diabasic rocks, Agattu................... 771

Faneto Formation................... 742

faulting, Agattu . ...................... 774

Attu.............................. 757

gabbro, Attu.......................... 746

glaciations............................ 788

hornblende andesite dikes, Attu.......... 751

Krugloi Formation ..................... 768

Massacre Bay Formation. ............... 741

Nevidiskov Formation. .................. 731

peat, Attu........................... 800

principal topographic features. . . ....... 780,784

pyrite mineralization. .................... 752

Alaid Island....................... 779, 782, 784, 787

Albite granite, Attu..................... 746

Alcan Harbor. . . . .......................... 775

Alexai Point, abandoned beach ridges....... 800

Alluvial fans. . . . . . . . . . . . . . . . . . . . . . . .

Alluvium. . . . . . . . . . . . . . . . 743,744

Alteration, basaltic tuffs..................... $\quad 770$

contact effects......................... 746

Altitude changes.......................... 801

Amphibolites, Attu. ....................... 721

Analyses, chemical, rocks of Near Islands..... 722 insoluble-residue, Chuniksak Formation.- 733

Andesite porphyry, hornblende, Attu....... 748

Animal life.............................. 713

Armeria Bay ............................ 758

abandoned beach ridges................ 800

shore platform ......................... $\quad 795$

Armeria Point, terrace..................... 782

A ttu Island . . . ............................ 714

abandoned beach ridges. . . ............... 800

accessibility.................... 711,712

age of faulting . . . . . .

age of peat............................ 800

albite granite ........................... 746

basement rocks....................... 747,812

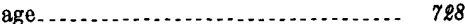

altered .......................... 746

amphibolite......................... 721

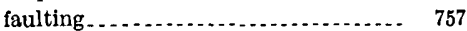

lavas............................... 719

measured sections................... 724

origin.............................. 728

pyroclastic....................... 718

sedimentary ........................ 715

thickness exposed . . ................ $\quad 715$

changes in altitude.................... 801

chemical analyses of rocks . . . . . . . . . ..... $\quad 722$

Chirikof Formation. ............... 714,798 
Attu Island-Continued

Chirikof Formation, depositional environ. ment......................... 738, 812 albite granite boulders.............. 747 diabase dikes....................... 746 Chuniksak Formation............. 714,7\$1,795 depositional environment. . . ........ 737,812 dikes.............................. 746, 749 faulting .......................... 757 structure........................ 753

climate............................... 713 dacite porphyry ....................... 749

diabase.............................. 744

Faneto Formation................. 715,742,746 depositional environment . . . . . . . . . 742,813 dikes.................................. 748 faulting ......................... 757 structure .......................... 753

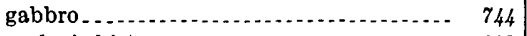
geologic history $\ldots . . . \ldots \ldots \ldots \ldots \ldots \ldots . .812$

glacial deposition

glacial erosion ........................ 784

glacial history . . . . . . . . . . . . . . .

hornblende andesite porphyry.......... 749

intrusive rocks . . . . . . . . . . . . . . . . . . . . 715,744

location .............................. 710

marine erosion . . . . . . . . . . . . . . . . . . 780

Massacre Bay Formation....... 714,739, 746, 751 depositional environment . . . . . . . ... 741,813 faulting ............................. 757 measured section, basement rocks _. $725,726,727$ Chuniksak Formation............. 735 depositional plain near Etienne Lake. 800 Nevidiskov Formation............... $\quad 730$ showing frost action................. 811

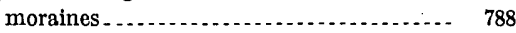

Nevidiskov Formation. . ............... 714,729 depositional environment . . . . . . .... 737,812 faulting .......................... 757 origin of bays........................... $\quad 797$

postglacial marine erosion . . .............. 792

postglacial stream action ................ 791

postglacial stream deposition . ........... 791

pyrite mineralization................... 751

quartz keratoph yre porphyry . .......... 747

sand dunes.................................. 802

shore platforms........................ 795

structure........................... 758

surficial deposits.......................... 748

taluses................................. 805

terrain type $\ldots \ldots \ldots \ldots \ldots$

turf-banked terraces................... 807

A ttu Mountain .............................. 788

A uburn Cove, faults...................... 756

marine shoreline deposition.............. 799

Austin Cove

\section{B}

Basalt_............... 764

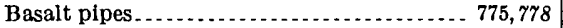

Basalt porphyry, Shemya Island............. 778

Basement rocks, Agattu.................... 758,768

Attu............................. 728,747

albitized

amphibolite, Attu.
Basement rocks-Continued Page faulting, Attu......................... $\quad 757$

geologic history .......................... 812

lavas, Agattu........................... 768

Attu............................... 719

measured sections, Attu.................. 724

origin, Attu........................... 728

pyroclastic.............................. 718,761

sedimentary ........................... 715,759

Shemya............................ 775,778

silicifed.................................. 746

structure, Attu........................ 753

Bays, Attu Island, origin.................. 797

Beach ridges, abandoned..................... 800

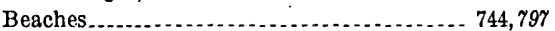
postglacial

Benches, glacial_........................... 785 sea....................... 756

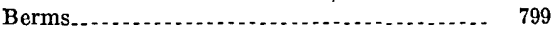

Berthold, S. M., analyst...................... 722

Binnacle Bay ...................... 758, 772, 785, 794 measured section near................... 764

shore platform ........................ 795

Bloom, Harold, analyst_.................. 733

Boulders, glacially transported............... 787

Breccia, tuffaceous.......................... $\quad 770$ volcanic................................. 718, 741 See also Tuff-breccia.

Brown, Roland, fossil identifications....... 736, 739

Brunette Cove

Canyons, submarine.................... 756, 757

Cape Sabak

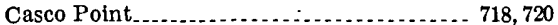

shore platform $\ldots . . \ldots \ldots \ldots \ldots \ldots$

structure............................ 753

Chirikof Formation . . ................... 714,788

albite granite boulders.................. 747

depositional environment . . . . . . . . . . . 738, 812

diabase dikes. . . . . . . 746

Chirikof Polnt . . . . . . . . . . . . . . . 739

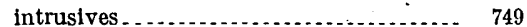

pyrite mineralization. . ................ 752

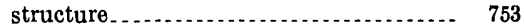

tuffs............................. 718, 719

type locality $\ldots \ldots \ldots \ldots \ldots$

Chodos, A. A., analyst.................. 722

Chuniksak Formation............... 714,791, 795 age .................................... 736

contact relations........................ 731

depositional environment . . . . . . . . . . . 737,812

dikes. . . . . . . . . . . 746,749

faulting . . . .

Insoluble-residue tests. . . . . . . . . . . . . . 733

measured section. ...................... 735

origin . . . . 737

petrographic description $\ldots . . . . . . . . . . . .732$

structure............................. 753

Chuniksak Point.................... 731, 736, 749

shore platform......................... 792,795

syncline.............................. 753

terrace................................ 781

CIPW normative minerals, rocks of Near

Islands. 


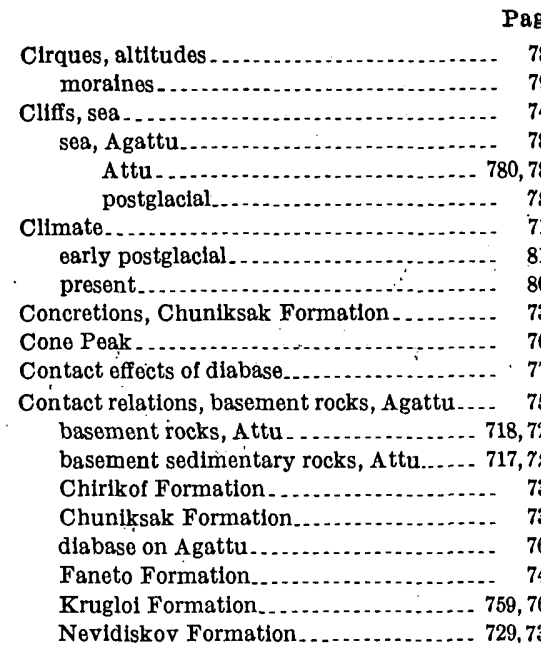

D

Daci te porphyry, Agattu. hornblende, Attu.

Shemya.................

Deposition, glacial.

marine, shoreline

stream, postglacial

Depositional environment, basement rocks, Attu.

718,728

basement pyroclastic rocks, Agattu....... 762

Chirikof Formation. . .................. 738, 812

Chuniksak Formation................. 737,812

Faneto Formation..................... . . 742, 813

Krugloi Formation................... 767,812

Massacre Bay Formation.............. 741, 813

Novidiskov Formation. ... . . . . . . . . . 737,812

summary ............................. 818

Diabase, Agattu....................... 768

Attu. ................................... 744

contact effects........................... 770

quartz $\ldots \ldots \ldots$

Diehm Creek................................ 744

Dikes, Agattu.................................. 758

Attu. ............... 744

dacito porphyry ...................... 771

diabase........................ 744

hormblende andesite porphyry ......... 749

quartz keratophyre.................... 747

relation to pyrite mineralization......... 752

Dune sand . . . . . . $80 \%$

\section{E}

Earlo Cove $744,756,800,801$

Engleman, E. E., analyst .................. 722

Erosion, glacial ........................... 784

marine, postglacial.

pro-Wisconsinan.

stream, postglacial.
Etienne Bay, deltos

dune sand.-. 802

glacial features near....................... $\quad 788$

marine shoreline deposition............... 799

raised beaches. ............................ 744

rockslide near........................... 805

Etienne Lake, measured section near ......... 800

Etienne Sea Valley . ...................... 756

\section{F}

Faneto Formation.................... 715, 742, 746 depositional environment............... 742, 813

dikes ..................................... 748

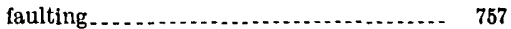

structure............................. 753

Faneto Hill. . . . . . . . . . . . . . . .

Faults................... 813

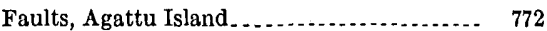

Attu Island ................................ 758

influence on topography ................. 780

relation to altitude changes.............. 801

relation to pyrite mineralization. ......... 752

Shemya Island. . . ........................ 778

strike-slip.............................. 774,813

Fieldwork procedures....................... 712

Folds, Agattu Island .................... 772

Attu Island .

Fossils, basement rocks, Shemya.......... 777 basement sedimentary rocks, Agattu ..... 761

Attu

Chirikof Formation.

Chuniksak Formation.................. 736

Nevidiskov Formation. ................ 731

Frost action............................ 797, 809

breaking of rock...................... 80 s

early postglacial............................ 811

formation of ponds and tussocks......... 809

mass movemont of material.............. 804

stone stripes........................... 808

turf-banked terraces.................... 805

\section{G}

Gabbro, Agattu $\ldots \ldots \ldots \ldots$

Attu................................ 744

quartz................................. 768

Geologic history, summary _.............. 812

Gilbert Ridge .............................. 785

Gillon Point ......................... 758, 772, 782

Glacial erratics.............................. 787

Glacial history $\ldots \ldots \ldots \ldots \ldots \ldots \ldots \ldots \ldots$

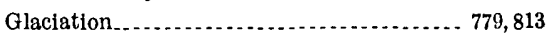

deposition........................... 787

erosion . . . .

history ................................ 788

snowline at glacial maximum. ........... 789

Glaciors, present. ........................ 790

rock................................... 805

Granite, albite, Attu $\ldots \ldots \ldots \ldots \ldots \ldots \ldots \ldots \ldots \ldots$

Habitation $\quad \mathrm{H}, \mathrm{I}, \mathrm{J}$

Holtz Bay ................................ 718, 731

basement-rock section near............. $\quad 725$

raised beaches.......................... 744 


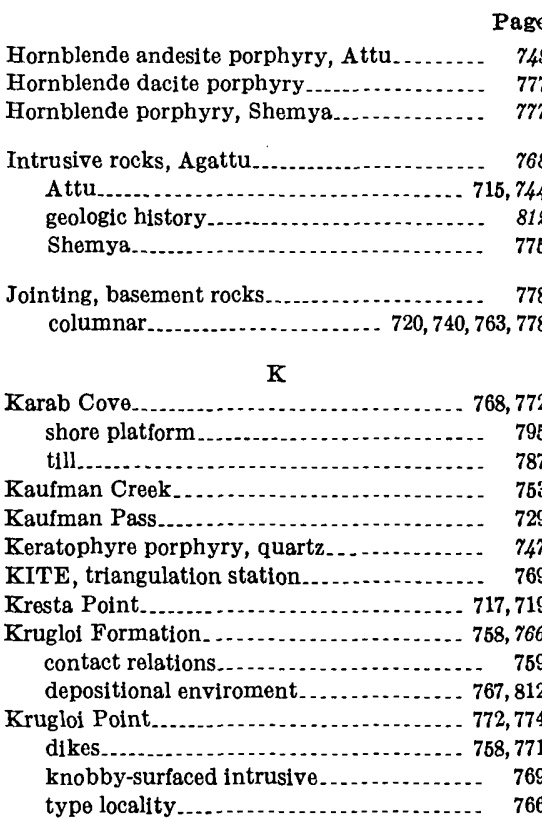

\section{$\mathbf{L}$}

Lakes, glacial

Lapilli tuff.

Lavas, Agattu.

Attu.

basaltic

basaltic andesite........ 739

keratophyric........................... 721

pillow, basement rocks . . ........ 717, 718, 719,763

Chirikof Formation................. 738

Kruglol Formation.................. 767

petrographic description............. $\quad 720$

relation to enclosing rocks............ 719

Loaf Island ............................. . 739, 741, 756

Location of area ............................ $\quad 710$

Lohman, K. E., fossil identification quoted ... $\quad 777$

Lookout Mountain ................... 739, 741, 752, 753

M

McDonald Cove, abandoned beach ridges..... 800 alluvium. faults

$772,773,774$

McNew Hill... . . . . . . . . . . . . . . . . . . . . . 739, 741

Marine shoreline deposition.................. $\quad 797$

Martinez Mountain........................... 788

Mass movement of rock debris, factors affecting.............................

Massacre Bay

basement-rock section. . . . . . . . . . . . .... $\quad 727$

berms

raised platforms. . ..................... $\quad 801$

section showing frost action............. 811

shore platform $\ldots \ldots \ldots \ldots \ldots \ldots$

till ...................................... 787

tuffs................................. $\quad 718$

type locality . . ...................... $\quad 739$
Page

Massacre Bay Formation. .......... 714, 799,746, 751 depositional environment . . . . . . . . . . . . 741, 813 faulting . . . ............................ 757

Measured sections, basement rocks, Agattu... $\quad 764$ basement rocks, Attu Chuntksak Formation................... $\quad 735$ depositional plain near Etienne Lake..... $\quad 800$ Kruglof Formation.................. 767 Nevidiskov Formation................ $\quad 730$ showing evidence of frost action. . ....... 811 Mikhail Point.......................... 717, 746, 780 Mineralization, pyrite ................. $715,749,751$ Monolith Point........................... 767

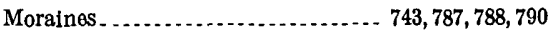
Mudflows, volcanic. .................... 741 Murder Point . ......................... 718, 719, 801 Murder Point peninsula, shore platform ..... 795

\section{N}

Nevidiskov Bay, West Arm .................. 741

Nevidiskov Creek valley, measured sections ......................... 729,735

Nevidiskov Formation................... 714,789 depositional environment . . . . . . . . . . ... 737, 812 faulting ............................... 757 origin................................... 737

Niggli values, rocks of Near Islands . . . . ..... 724

Nizki Island . . . . . . . . . . . . . . . . 789 glacial erosion......................... 787 marine terrace........................ 784

Nodules, Chuniksak Formation........... 734 North Pass... Northeast Bluff, terraces . ................... 781

\section{$\mathbf{0}, \mathbf{P}$}

Otkriti Bay . .................... $758,768,769,772$

Outwash, glacial. . . . . .

Patricia Bight..................... 768, 794, 795, 801

Patricia Point........................... 769

Peaceful River

Peaceful Valley ... . . . . . . . . . . . . . . . . . 718, 739

Peak M-N . . . . . . . . . .

Peat. . . . . . .

Personnel. . . . . . . . . . . . . . . . . . . . .... 711

Petrographic description, albite granite, Attu. $\quad \mathbf{7 4 7}$ albitized quartz diabase, Attu........... 745 amphibolite, Attu. .................... 721 andesite, Attu.................... 740 basaltic andesite, Attu................. $\quad 740$ basaltic lava, Attu................... 721 basement lava, Agattu................. 764 Chuniksak Formation ................... 732 dacite porphyry, Agattu................ $\quad 770$

Shemya......................... 777 diabase sill, Attu hornblende andesite, Attu $\ldots . . . . . . .750,751$ pillow lava, Attu................... $\quad 720$ porphyritic quartz keratophyre, Attu.... $\quad 748$ quartz diabase, Agattu. . .............. 769, 770 quartz gabbro, Attu.................. 745 quartz keratophyre, Attu............... 721 
Petrographic description-Continued

spilitic basalt, Attu

tuff, Agattu

tuff-breccia, Agattu.................... $\quad 770$

tuffaceous breccia, Agattu ............... $\quad 770$

Phillips, H. F., analyst.................... 722

Pillow lavas, basement rocks....... 717, 718, 719,763 Chirikof Formation................... 738

Kruglol Formation.................... 767

petrographic description................ $\quad 720$

relation to enclosing rocks. . .............. 719

Pipes, basalt........................... 775, 778

Platforms, changes in altitude............... 801 shore, postglacial...................... 792, 794 wave-cut. . . ................... 779,780,781,789

Ponds, glacial. .............................. 786 produced by frost action................ 809

Postglacial marine action.................... 792

Postglacial stream action...................... 791

Previous investigations.................... 714, 779

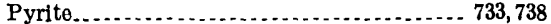

Pyrite mineralization................... 715, 749,751

Pyroclastic rocks, Agattu..................... 761

Attu............................... 718

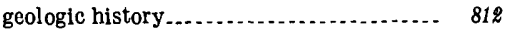

Shemya . . . . . . . . . .

\section{$\mathbf{Q}, \mathbf{R}$}

Quartz diabase

Quartz gabbro.............................. 768

Quartz keratophyre porphyry, Attu ........ $\quad 747$

References cited

Rock glaciers.

Rockslides

Sabak, Cape

772,782

Sand, dune.

Sanders Cape.............................. 719

Schuler Beach............................ 738, 739

Scripps Institution of Oceanography.......... $\quad 712$

Sea bench .............................. 756

Sea cliffs . . . . .

Agattu ................................ 781

Attu . . .

postglacial............................ 792

Sea-level changes .......................... 780, 790

Sedimentary structures, basement rocks, Agattu . ...................... 759, 761

basement rocks, Attu.................. 717,728

Chirikof Formation . . . . . . . . . . . . . . . 738, 739

Faneto Formation...................... 742

Kruglol Formation .................... 766

Semichi Islands.......................... 710

glaciation............................... 789

marine croslon......................... 788

postglaclal stream action

postglaclal stream deposition. ............ 792

Shemya Island ........................... $\quad 775$ accessibility . . . . . . . . . . . .

basalt porphyry ....................... $\quad 778$

basement rocks......................... $\quad 776$

chemical analyses of rocks ............... 722

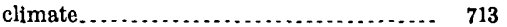

Shemya Island-Continued Page

eolian action........................... 802

glacial deposition....................... 787

glacial eroslon ........................... $\quad 787$

hornblende porphyry.................. $\quad 777$

Intrusive rocks. ........................ 776

jointing in basement rocks................ 778

location

postglacial marine erosion. ................ 798

pyroclastic rocks...................... 775, $77 \gamma$

structure ............................... 778

surficial deposits....................... 775

wave-cut platform .................... 779,783

Shore platforms . ........................ 756

postglacial............................ 792,794

role of frost action ........................ 803

Shoreline deposition, marine................ $7 \theta \gamma$

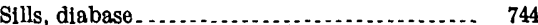

Skoot Cove.................................. 775

Snowline at glacial maximum................. 789

Solls....................................... 713

Staircase ponds............................ 810

Steller Cove, albite granite................. 746

hornblende andesite and dacite dikes.... 749

quartz keratophyre dikes................. $\quad \mathbf{7 4 7}$

basement-rock section near............... 726

faults.................................... 756

marine deposition...................... $\quad 797$

perched alluvium.

Steller Valley, West, fault scarp.............. $\quad 780$

Stewart, Ralph, fossil identification quoted... $\quad 736$

Stocks, hornblende andesite porphyry........ $\quad 749$

Stokes, R. H., analyst....................... 722

Stone stripes . . . .

Streams, postglacial action.................. 791

Striations . . . . . .

Structure, Agattu...........................

Attu. ................................... 758

relation to topography $\ldots \ldots \ldots \ldots \ldots \ldots . .780$

Shemya.............................. $\quad 778$

Surficial deposits, Agattu.................. 768

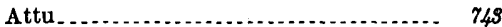

involutions................................. 811

Shemya................ 775

Surficial geology ......................... 778

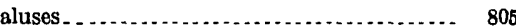

Temnac Bay .............................. 718, 753

Temnac Point_.......................... 718, 747

Temnac River alluvial fill................... $\quad 743$

Temnac Valley ............................ $\quad 756$

alluvial fans. . . . . . . . . . .

Terraces, correlation...................... 784

marine, Agattu ....................... 788

Attu............................... 780

Semichi Islands.................... 784

turf-banked, relation to frost action....... 805

Terrain, principal types.................... 779

Theodore Point. . ..................... 719, 720, 729

Thrust ponds. ....................... 810

Till . . . . . . . . . . . .

Topography, relation to strata and structure.. $\quad 780$ submarine........................ $\quad 757$ 


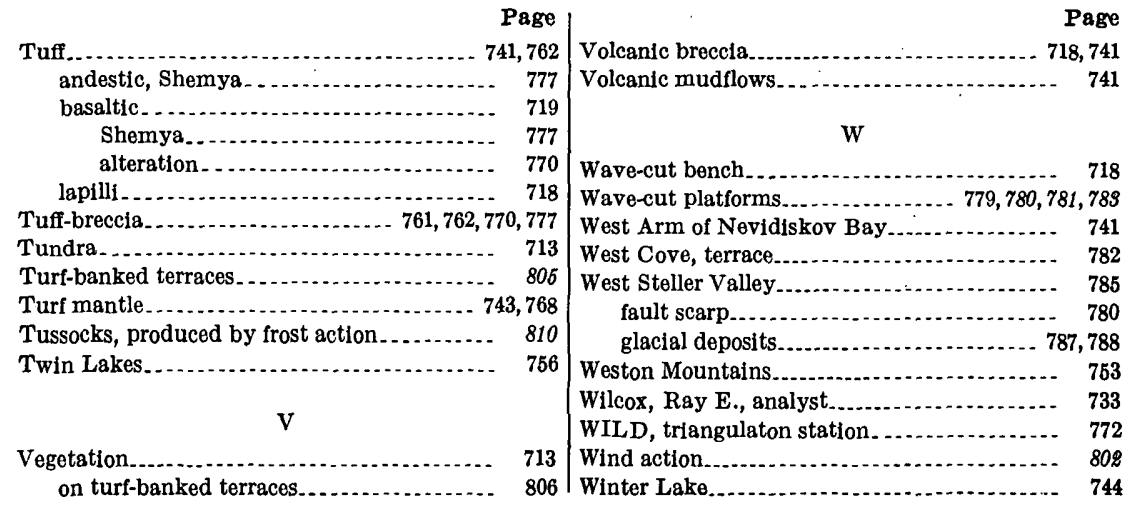

